\title{
UN NOU SIT DE LA SFÂRȘITUL EPOCII BRONZULUI PE VALEA MUREȘULUI MIJLOCIU. RAPORT PRELIMINAR ASUPRA CERCETÃRILOR ARHEOLOGICE PREVENTIVE DE LA AUREL VLAICU-OBREZA
}

\author{
CORINA BORS, LUCIANA RUMEGA-IRIMUȘ, VLAD RUMEGA-IRIMUS, \\ SEbastian Dobrotă, CĂTĂLIN RișCUȚA, Costin ȚUṬUIANU
}

\author{
A NEW SITE OF THE LATE BRONZE AGE ON THE MIDDLE MURES VALLEY. \\ PRELIMINARY REPORT REGARDING THE PREVENTIVE ARCHAEOLOGICAL EXCAVATIONS \\ AT AUREL VLAICU-OBREZA
}

The preventive archaeological research campaign 2012 on the newly discovered site Aurel VlaicuObreza (Hunedoara County) was occasioned by the construction works of A1 motorway, developed along the $4^{\text {th }}$ pan-European transportation corridor, runining from West to East along the middle Mures valley. The site was preliminary identified in autumn 2008 , following the archaeological survey made by a team of the Museum of Dacian and Roman Civilisation (Deva). Later on, when the exact location of the future motorway was set, a more thorough field survey was undertaken by a team of the National History Museum of Romania. Still in autumn/winter 2011 the archaeological site was overlapped by an apple trees orchard, which impacted significantly the site's integrity and stratigraphy, along with an irrigation underground system (water supply pipes).

The preventive archaeological investigations lasted 6 weeks (July-August 2012) and confirmed an important presence of archaeological vestiges. Throughout an open area archaeological excavation, between $\mathrm{km} \mathrm{4+900} \mathrm{and} \mathrm{km} \mathrm{5+150}$ of the Al motorway, section 1 was fully investigated an area of about 1 ha, where 133 archaeological complexes (semi-sunken pit dwellings, refuse pits, extraction pits and remains of the socalled "culture layer") were oulined. By opening 7 main trenches $\left(\mathrm{S}_{001}-\mathrm{S}_{007}\right)$ was possible to observe the concentration of archaeological features in the area between $\mathrm{km} 5+020$ and $\mathrm{km} 5+150$, further confirmed by opening of 11 excavation areas $\left(\mathrm{S}_{\Gamma}-\mathrm{S}_{\mathrm{X} I}\right)$.

The archaeological discoveries made at Aurel Vlaicu - Obreza indicate the existence of a prehistoric settlement, most probably with a single layer of habitation (significantly disturbed in the upper part). The absence of certain constructive elements like walls, floor boards, hearths etc. in situ are determining - at least for the moment - a cautious approach regarding the functionality of the archaeological vestiges. Also worth to mention the rather small number of pottery found, the high degree of fragmentation of the ceramic material (except six vessels broken in situ), but the large quantity of animal bones. Since the post-excavation analysis of the archaeological material is on-going one only can consider certain work hypothesis in regard to the site's chronology and functionality. Other finds made in here are bronze objects, bone tools (including crenated scapulae) and fragmentary lithic objects. There have been found a series of fragments characteristic to the Noua type pottery, and fragments of black polished channelled pottery, specific to the early Hallstatt period.

Based on the preliminary post-excavation analysis, the site from Aurel Vlaicu-Obreza is a prehistoric settlement of the Late Bronze Age / Early Iron Age. Within certain archaeological complexes were found in association elements typical for the Noua culture (e.g. handles with knobs, crenated scapulae) with black polished channelled pottery. These discoveries bring new evidence for a much thorough analysis regarding the transition period of Late Bronze Age to Early Iron Age in south-west Transylvania.

KEYWORDS: Late Bronze Age, Early Hallstatt, Noua culture, Gáva culture, Cugir-Band group CUVINTE CHEIE: Bronz târziu, Hallstatt timpuriu, cultura Noua, cultura Gáva, grupul Cugir-Band

\section{INTRODUCERE}

Existenţa sitului de la Aurel Vlaicu - Obreza a fost semnalată iniţial în toamna anului 2008, în contextul efectuării diagnosticului arheologic preliminar de către o echipă de arheologi de la Muzeul Civilizaţiei Dacice şi Romane (Deva) pe traseul - mai mult sau mai puţin cert la acea dată 
- autostrăzii A1: Orăștie - Sibiu, porțiunea situată în jud. Hunedoara' ${ }^{2}$ Cu acel prilej, au fost realizate numai o serie de recunoaşteri de teren - pe o arie cu mult mai extinsă decât variantele de traseu prezumtiv ale viitoarei autostrăzi -, precum și o serie de investigaţii documentare (PI. I). Ulterior, având în vedere definitivarea proiectului viitoarei căi rutiere, o echipă de specialişti din cadrul Muzeului Național de Istorie a României a realizat - în toamna anului 2011 - un diagnostic teoretic şi de teren, inclusiv o serie de sondaje care să permită o delimitare mai exactă a zonelor cu potenţial arheologic ce urmau să fie direct afectate de construirea viitoarei autostrăzi ${ }^{2}(\mathbf{P I} . \mathbf{V}) . \mathrm{Cu}$ acelaşi prilej a fost întreprinsă şi o primă cercetare a surselor documentare geografice și istoricoarheologice cu privire la arealul în care este amplasat situl în discuție (Pl. II).

Se cuvine menţionat faptul că până în toamna/iarna anului 2011 zona sitului era încă acoperită de o livadă de pomi fructiferi, care a afectat semnificativ configuraţia şi stratigrafia sitului. De asemenea, în zona sitului a existat anterior şi un sistem de irigaţie cu elemente subterane (conducte de aducţiune) care a afectat, de asemenea, depunerile arheologice (PI. I, III).

În contextul derulării Programului Național de Cercetare „Autostrada” ${ }^{3}$, pornind de la solicitarea firmei STRABAG S.R.L. adresată Muzeului Naţional de Istorie a României, în prima parte a trimestrului I al anului 2012, între cele două părţi a fost încheiat un contract de prestare servicii în vederea efectuării lucrărilor de cercetare arheologică preventivă pe traseul viitoarei autostrăzi A1: Orăştie - Sibiu, Lot 1: Orăştie - Sebeş (km 0+000-24+110), în scopul întocmirii documentațiilor de specialitate necesare derulării procedurii de descărcare de sarcină arheologică, în conformitate cu prevederile legale.

Per ansamblu, raportat la întregul lot 1 al autostrăzii amintite, evaluarea arheologică (teoretică şi de teren) desfăşurată în perioada octombrie - decembrie 2011 , cât şi cercetarea arheologică preventivă efectuată în perioada lunilor martie - octombrie 2012 au fost realizate în conformitate cu legislaţia în vigoare privind protejarea patrimoniului arheologic (OG nr. 43/2000 cu modificările ulterioare, OMCC nr. 2392/2004 şi OMCPN nr. 2613/2011), în baza autorizațiilor emise de către Ministerul Culturii şi Patrimoniului Naţional, coordonarea generală a proiectului fiind asigurată de către Muzeul Național de Istorie a României, dr. Paul Damian fiind responsabil de proiect. În ceea ce privește situl arheologic de la Aurel Vlaicu -Obreza, echipa de cercetare în teren a fost coordonată de dr. Corina Borş (responsabil ştiinţific, arheolog specialist), fiind alcătuită din cinci arheologi, dintre care trei angajaţi contractuali în cadrul Muzeului Național de Istorie a României, respectiv doi arheologi angajați permanenți ai Muzeului Civilizației Dacice și Romane (Deva), aceștia din urmă fiind cooptați în colectivul de cercetare în baza unui contract instituțional de subcontractare încheiat între cele două muzee amintite ${ }^{4}$.

Cercetările arheologice cu caracter preventiv, efectuate în vara anului 2012 , de-a lungul a şase săptămâni (iulie - august 2012; program de lucru de 10 ore zilnic, 6 zile pe săptămână cu excepţia zilelor cu intemperii), au confirmat prezenţa substanţială a potenţialului arheologic semnalat anterior, aducând însă o serie de reconsiderări de ordin cronologic, fiind identificate şi investigate exhaustiv 133 de complexe arheologice distribuite pe o suprafaţa de circa 1,75 ha, între km 4+900 şi 5+150 ai traseului autostrăzii A1: Orăştie - Sibiu, tronson 1 (km 0-24+000) (PI. III-VI).

În acest context a fost investigată exhaustiv, prin săpătură arheologică de tip ,open area excavation", o suprafaţă de $9.521 \mathrm{~m}^{2}$, situată între $\mathrm{km} \mathrm{4+900} \mathrm{şi} 5+150$ ai autostrăzii $\mathrm{Al}$, anume în ampriza acesteia cu o deschidere de circa $70-75 \mathrm{~m}$. Practic, prin deschiderea a șapte secţiuni magistrale (identificate cu siglele $\mathrm{S}_{001}-\mathrm{S}_{007}$ ) s-a putut observa preliminar faptul că vestigiile arheologice se concentrau preponderent în zona cuprinsă între km $5+020$ şi $5+150$; odată cu deschiderea suprafeţelor de cercetare (identificate cu siglele $\mathrm{S}_{\mathrm{T}}-\mathrm{S}_{\mathrm{XI}}$ ) acest fapt a fost clar confirmat.

\footnotetext{
${ }^{1}$ Riscuta et alii 2011,62

${ }^{2}$ Damian et alii 2012, 280

${ }^{3}$ Programul național de cercetare amintit a fost instituit prin Ordinul comun nr. 635/2492/2010 al Ministerului Transporturilor şi Infrastructurii și al Ministerului Culturii şi Patrimoniului Naţional, textul integral al documentului legislativ fiind disponibil online la adresa http://www.cimec.ro/Legislatie/Autostrada-653-2010-MinisterulTransporturilorsiInfrastructurii.pdf.

${ }^{4}$ Borş et alii 2013, 211-212

${ }^{5}$ Principiul pe care se bazează săpătura de tip „open-area excavation” (n.n. săpătură în suprafałă deschisă) este acela că astfel, în chip ideal, este investigat întregul sit, prin expunerea, înregistrarea şi îndepărtarea fiecărui ,,depozit” arheologic, în mare măsură în ordinea inversă a formării respectivelor depuneri. De exemplu,vezi Drewett 2011, 92-93.
} 
Date fiind caracteristicile și distribuţia complexelor arheologice identificate, a fost posibilă extinderea săpăturii arheologice spre nord cu circa 15-20 m dincolo de zona de impact propriu-zis a traseului viitoarei autostrăzi, între km $5+020$ şi 5+150, până la limita de proprietate rezultată din exproprierile pentru construirea acestei căi rutiere (PI. V-VI).

Cercetarea arheologică preventivă a sitului în discuție a urmărit să determine, pe cât mai mult posibil, natura și distribuția spaţială a eventualelor vestigii arheologice în cuprinsul zonei direct afectate de viitoarele lucrări de construire a autostrăzii amintite. Astfel, pentru atingerea obiectivelor stabilite prin proiectul de cercetare au fost utilizate diverse metode, tehnici şi bune practici de specialitate uzuale în domeniul arheologiei preventive şi cercetării de teren care au vizat salvgardarea prin înregistrare (preservation by record ${ }^{6}$ ) a contextelor şi vestigiilor arheologice identificate în cuprinsul sitului în discuție.

Prezentul articol prezintă o serie de date preliminare generale referitoare la rezultatele cercetărilor arheologice preventive efectuate în perimetrul sus-menţionat, în vara anului 2012, respectiv ale analizelor post-săpătură desfășurate începând din toamna aceluiași an și până în prezent în legătură cu materialele arheologice descoperite în cadrul sitului Aurel Vlaicu - Obreza. Facem precizarea că, la data apariției acestui articol, este în curs de pregătire publicarea integrală a rezultatelor cercetărilor arheologice preventive, efectuate în vara anului 2012 în cadrul sitului Aurel Vlaicu - Obreza, volumul urmând să apară în cadrul seriei monografice editate de Muzeul Național de Istorie a României.

\section{DATE FIZICO-GEOGRAFICE PRIVIND SITUL}

Situl arheologic Aurel Vlaicu - Obreza este situat la circa $0,50 \mathrm{~km}$ sud de traseul DN 7/E 68, între localităţile Şibot (jud. Alba), spre est şi Orăştie (jud. Hunedoara), spre vest, aproximativ la limita administrativă dintre cele două judeţe (coordonate: $45^{\circ} 54^{\prime} 37^{\prime \prime} \mathrm{N} / 23^{\circ} 16^{\prime} 40^{\prime \prime} \mathrm{E}$ ). Din punct de vedere administrativ, situl este localizat pe teritoriul județului Hunedoara, unitate administrativteritorială aflată în partea sud-vestică a Transilvaniei şi care ocupă o parte din bazinele hidrografice ale Mureșului şi Jiului (PI. I).

Din punct de vedere geografic, situl în discuţie se află poziţionat în cuprinsul Culoarului Orăştiei, situat pe cursul mijlociu al Mureşului, intre localităţile Sebeş şi Orăştie ${ }^{7}$. Culoarul Orăştiei este mărginit la nord de Carpaţii Apuseni de sud (Munţii Metaliferi şi Trascăului), iar la sud de Carpaţii Meridionali (Munţii Şureanu).

Din punct de vedere geologic, teritoriul judeţului Hunedoara suprapune două mari unităţi tectonice structurale: autohtonul danubian şi pânza getică ${ }^{8}$. Astfel, Carpaţii Meridionali aparţin zonei cristalino-mezozoice, iar Carpaţii Apuseni de sud zonei sedimentar-vulcanice. Culoarul Orăştiei are un caracter deluros în partea sa sudică, în vreme ce partea sa nordică este alcătuită din terase și lunci ${ }^{9}$.

\footnotetext{
${ }^{6}$ În general, sub acest concept se înţelege identificarea și cercetarea exhaustivă a unor situri (vestigii) arheologice, efectuate în contextul ameninţării integrităţii acestora de către viitoare activităţi de construire sau în cel al realizării unui studiu de impact asupra mediului (situaţie prevăzută în Convenţia La Valletta şi legiferată în legislaţia românească referitoare la protejarea patrimoniului arheologic). $\mathrm{O}$ asemenea abordare este complementară - după caz, în funcţie de semnificaţia şi importanţa descoperirilor - demersului de conservare in situ a unora dintre vestigii, precum și cu o serie de măsuri preventive ce pot fi întreprinse pentru a salvgarda un sit identificat, dar ne-excavat. Conceptul de ,păstrare prin inregistrare"/,salvgardare prin studiu" este relativ nou și neclar explicitat - pentru moment - în cadrul politicilor de protejare a patrimoniului arheologic prevăzute de legislaţia românească de specialitate, dar este aplicat, pe scară largă, în numeroase tări europene şi în SUA. Pentru mai buna înţelegere a acestui concept în practica arheologică internaţională vezi: preservation by record - Roskams 2001, 35-36; Grant, Gorin, Fleming 2008, 348; PPG16, sectiunea 25; mitigation through data recovery - Neumann, Sanford 2001, 201-242; Greene 2002, 104-105; Grant, Gorin, Fleming 2008, 30, 348; sauvegarder par l'étude - în sensul dat în Franţa de legea arheologiei preventive, respectiv Legea $\mathrm{nr} .2001-44 / 2001$.

${ }^{7}$ Orghidan 1969,112

$8 * * * 1982,513$

$9 * * * 1982,514$
} 
În ceea ce priveşte reperele hidrografice, zona sitului Aurel Vlaicu - Obreza este mărginită la nord de valea mijlocie a Mureşului, la est de valea râul Cugir şi la vest de pârâul Vaidei. Situl arheologic este situat în partea nordică a Dealului Înalt (altitudine maximă $498 \mathrm{~m}$ ), aparţinând Dealurilor Subcarpatice Meridionale, fiind situat în zona de contact cu lunca extinsă a Mureşului mijlociu.

Dealurilor înalte din acest areal le corespund solurile brune și brun-roșcate de pădure, slab sau puternic podzolite sau podzolite secundar, în vreme ce pe terasele şi dealurile piemontane din depresiuni sunt frecvente asocierile de cernoziomuri, soluri brune de terasă, solurile brune şi cele brun roşcate de pădure ${ }^{10}$. De-a lungul văii Mureșului, râu având o luncă extinsă, există soluri aluviale, gleice şi cernoziomuri levigate.

Micro-zona geografică unde este situat situl este caracterizată printr-un climat continental moderat de deal.

Deși documentele cartografice din a doua jumătate a secolului al XVIII-lea nu arată clar acest lucru, este de presupus că până în a doua jumătate a secolului XX zona sitului va fi fost acoperită de păşuni şi/sau păduri de foioase, ulterior însă aceasta a fost defrişată pentru practicarea agriculturii, iar după anii '70 pentru plantarea și exploatarea unei livezi de pomi fructiferi (meri, peri) (PI. II).

\section{DATE ISTORICO-ARHEOLOGICE REFERITOARE LA ZONA LOCALITĀṬII AUREL VLAICU}

Cu privire la localitatea Aurel Vlaicu, jud. Hunedoara (denumită în trecut Binținți, respectiv în germană Benzenz sau Benzendorf, iar în maghiară Bencenc), există o serie de semnalări de interes istorico-arheologic în literatura de specialitate. Este vorba exclusiv de descoperiri întâmplătoare efectuate în cursul secolului trecut în mai multe puncte din vecinătatea localităţii amintite. Informaţii destul de generale cu privire la aceste descoperiri se regăsesc şi în Arhiva Repertoriului Arheologic al României " , respectiv în Repertoriul arheologic al judetului Hunedoara $^{12}$. Astfel, principalele descoperiri arheologice din vecinătatea sitului cercetat de noi în vara anului 2012 sunt:

- la vest de sat, pe prima terasă de pe malul stâng al Mureșului, a fost indicată existenţa unei aşezări preistorice încadrabilă în perioada timpurie a epocii bronzului ${ }^{13}$;

- din punctul numit După Sat provin materiale ceramice specifice bronzului timpuriu (grupul Copāceni) ${ }^{14}$;

- la est de sat, în apropierea clădirilor IAS au fost semnalate materiale ceramice aparţinând culturii Wietenberg ${ }^{15}$;

- de la nord de sat, către Mureş, în punctul numit Voievozi, provin o serie de materiale ceramice aparținând culturii Wietenberg (începutul fazei a III-a) ${ }^{16}$;

- din zona localităţii, fără alte precizări, provine un vas caracteristic manifestărilor de tip Balta Sărată ${ }^{17}$;

- din zona localității, din inventarul unor complexe, provin o serie de materiale „barbotinate”, asociate, în cazul unui complex cu materiale de tip Band - Cugir ( $\mathrm{Ha} \mathrm{A}_{1}-$ $\mathrm{Ha} \mathrm{A}_{2}$ ), caracteristice perioadei de la sfârşitul epocii bronzului şi începutul primei epoci a fierului ${ }^{18}$;

- la sud de sat, în zona căii ferate Arad - Teiuş, cu ocazia unor lucrări la terasament, în anul 1957 a fost descoperit un depozit de bronzuri (constituit dintr-un fragment din partea

\footnotetext{
$10 * * * 1980,33$

${ }^{11}$ Resursā disponibilă on-line la adresa http://www.cimec.ro/scripts/ARH/RAR-Index/sel.asp (accesat 15.10.2014)

12 RAH, 23

${ }^{13}$ Popa 1998, 52

${ }^{14}$ Popa 2011, 168

${ }^{15}$ Andriţoiu 1979, 16

${ }^{16}$ Popa 2011,210, n. 832 cu referințele bibliografice anterioare

${ }^{17}$ Popa 2011, 220-221

${ }^{18}$ Popa, Totoianu 2010, 187, 208-209, pl. 73/3, 20-22; Popa 2011, 235
} 
superioară a unei spade cu limbă la mâner şi o seceră cu cârlig fragmentară), încadrat în seria Uriu - Domăneşti (Uriu - Opályi), respectiv databil la nivel de $\mathrm{Bz} \mathrm{D}-\mathrm{Ha} \mathrm{A}^{19}$;

- la sud de sat, în punctul Izvorul Rece (în imediata vecinătate a traseului DN 7/E 68), pe o terasă situată la est de localitate, mărginită la vest de un pârâu și la sud de calea ferată Arad - Teiuş, au fost recoltate fragmente ceramice databile în perioada Hallstatt-ului timpuriu şi epoca romană ${ }^{20}$;

- tot din zona de la sud de sat, în punctul Izvorul Rece (în imediata vecinătate a traseului DN 7/E 68), au fost recent semnalate o serie de materiale hallstattiene timpurii (Ha A) care provin din două complexe (parțial distruse) ale unei stațiuni preistorice ${ }^{21}$;

- din zona localităţii, fără alte precizări, din prima jumătate a secolului XX este menţionată o ceaşcă databilă în perioada hallstattiană, aflată, cel mai probabil, în colecţiile Muzeului Brukenthal (Sibiu) ${ }^{22}$;

- la nord de sat, către Mureş, în punctul numit Voievozi (sau Voivoda), există menţiuni referitoare la vestigii din epoca romană şi post-romană (secolele IV-V) ${ }^{23}$;

- din vatra satului provin o serie de materiale din epoca romanăa ${ }^{24}$;

- hărțile iosefine din a doua jumătate a secolului al XVIII-lea cuprind o serie de mențiuni despre existența unor tronsoane de drum vechi roman (Romer Weg / Alter Romer Weg / Drum Trajan) între actualele localități Aurel Vlaicu (fost Binținți) și Gelmar ${ }^{25}$;

- din zona localităţii, probabil fiind găsit chiar în albia râului Mureș (așadar putând să provină din amonte), provine un fragment dintr-o buză de cazan medieval (secolele XIXIII), păstrat, cel mai probabil, în colecţiile Muzeului Brukenthal (Sibiu) ${ }^{26}$;

- din zona localității, fără alte precizări, provin o serie de materiale medieval timpurii ${ }^{27}$;

- în anul 1291 este atestată delimitarea hotarelor satului Binținți (terra Sohtheluk) ${ }^{28}$;

- în hotarul estic al localității, către Şibot, este semnalată existența unor movile de pământ (morminte colective), puse în legătură cu marea bătălie de la Câmpul Pâinii din anul $1479^{29}$.

\section{SCURTÃ PREZENTARE A STRATEGIEI DE CERCETARE ARHEOLOGICĂ}

Campania de diagnostic arheologic de teren s-a desfăşurat în toamna anului 2011; cu acest prilej, între km 4+900-5+150, au fost deschise 15 sondaje arheologice (identificate cu siglele $\mathrm{S}$ $400-\mathrm{S} 405 ; \mathrm{S} 632-\mathrm{S} 640)^{30}$. Situl se află situat pe o terasă cu altitudine medie (circa $420-450 \mathrm{~m}$ ), în raza administrativ-teritorială a localităţii Aurel Vlaicu (com. Geoagiu, jud. Hunedoara). Zona sitului a fost anterior afectată de o plantaţie de pomi fructiferi (meri) şi de o serie de canale de aducţiune componente ale unui sistem de irigaţie existent anterior aici, probabil în legătură cu infrastructura fostei staţiuni de cercetare pomicolă şi plantaţiile de hamei existente încă în anii ' 90 ai secolului trecut la poalele terasei, spre nord, către traseul DN 7/E 68. De asemenea, la începutul

${ }^{19}$ Rusu 1963, 205; Alexandrescu 1966, 131; Berciu, Popa 1967, 73-84; Petrescu-Dâmboviţa 1977, 52, pl. 22/11-12; Andriţoiu 1988-1991, 28; Bratu 2009, 230; Popa, Totoianu 2010, 217

${ }^{20}$ Andriţoiu 1979, 15; Giurgiu-Ardeu 1995-1996, 194-195; Popa 2002, 28; Popa 2011, 393, 402

${ }^{21}$ Popa, Totoianu 2010, 203-217 şi urm., 238, 244, 251, 280-282

${ }^{22}$ Andrieșescu 1912, 68, nr. 145; Horedt 1944, 108, nr. 44

${ }^{23}$ Andriţoiu 1979, 15-16; Blăjan 1989, 292, 318-319, 330; Popa 2002, 29; Popa 201 1, 386, 392

${ }^{24}$ Popa 2011, 389, 403

${ }^{25}$ Popa 2011, 385

${ }^{26}$ Popa 2011,427 cu referințele bibliografice anterioare.

${ }^{27}$ Popa 2011, 432

${ }^{28}$ Popa $2011,440,454,639$

${ }^{29}$ Popa 2011, 606, 611-614

${ }^{30}$ Pentru informații în detaliu vezi documentaţia de specialitate, anume Raport de diagnostic arheologic, realizată de către Muzeul Naţional de Istorie a României şi predată către Ministerul Culturii - Comisia Națională de Arheologie și Direcția pentru Cultură şi Patrimoniu Cultural Național a județului Hunedoara; un exemplar al acestei documentații se păstrează în arhiva Secției de Arheologie Pre- şi Protoistorică, Clasică, Medievală și Preventivă a Muzeului Naţional de Istorie a României. Pentru date generale vezi Damian et alii 2012, 280. 
anului 2012 zona estică a sitului a fost parţial afectată de amenajările de şantier pentru construirea autostrăzii. Din punct de vedere stratigrafic, cu prilejul realizării sondajelor s-a constatat următoarea situaţie:

- nivel de sediment de culoare brună-maronie, cu textură preponderent argiloasă, afânat, perturbat de lucrările agricole (arătură), strat vegetal actual; dispus de la nivelul actual de călcare (nivel 0 ) până la cota de $-0,30 \mathrm{~m}$;

- nivel de sedimente de culoare neagră, compact, lutos, cu fragmente ceramice, pigmenţi de cărbune, pietricele, oase, chirpici, nivel de cultură, dispus de la adâncimea de $0,30 \mathrm{~m}$ până la $0,55 / 0,90 \mathrm{~m}$;

- nivel de sediment de culoare brun roşiatică, compact lutos, cu fragmente ceramice şi oase în compoziţie. Acesta este nivelul de la care sunt surprinse complexele, dispus de la adâncimea de $0,55 / 0,90 \mathrm{~m}$ până la $1,25 / 1,40 \mathrm{~m}$.

Pe baza observaţiilor efectuate şi a materialului arheologic recoltat cu prilejul realizării diagnosticului în teren a fost delimitată o zonă de habitat, databilă în epoca bronzului. A fost identificată preliminar o locuinţă de suprafaţă cu podea, amenajată din pietre de mici dimensiuni şi o vatră de formă circulară. Totodată au fost recoltate o serie de artefacte (material ceramic), ce se datează în Hallstatt-ul timpuriu, ceea ce părea să indice posibila existentă a unui sit pluristratificat ${ }^{3 \mathrm{H}}$. Concluziile studiilor de diagnostic arheologic $(2008,2011)$ au fost numai parţial confirmate - după cum se va vedea în cele ce urmează - de cercetările arheologice preventive din vara anului 2012.

Odată cu inițierea cercetărilor arheologice preventive, în primăvara anului 2012, ținând cont de natura şi caracteristicile sitului, metodologia de lucru a cuprins patru faze principale: faza de documentare, faza de evaluare de teren (periegheză în imediata vecinătate a sitului), cea de cercetare de teren propriu-zisă (săpătură arheologică preventivă) şi cea de analiză şi procesare postsăpătură. Este de remarcat faptul că echipele de lucru şi-au modificat componenţa de la faza de diagnostic preliminar la cea de diagnostic de teren și apoi la cea de cercetare arheologică preventivă. Pe cale de consecință, faza de documentare a fost reluată și aprofundată cu ocazia cercetărilor din anul 2012. În principal, s-a avut în vedere realizarea unei documentări de arhivă, pe cât mai completă posibil, cu privire la diversele categorii de surse istorico-arheologice (texte, fotografii, hărţi, schiţe etc.), respectiv identificarea şi verificarea referinţelor bibliografice relevante. În mod evident, s-au adăugat examinări ale unor surse cartografice, aerofotografice de arhivă, dar şi a unor ortofotoplanuri mai recente, precum şi realizarea unor observaţii directe pe teren (în imediata vecinătate a traseului autostrăzii din zona de referință) pentru identificarea altor perimetre susceptibile să conţină vestigii arheologice, având în vedere semnalările anterioare cunoscute din bibliografia de specialitate.

Obiectivele campaniei de cercetare arheologică preventivă din vara anului 2012 au constat în stabilirea limitelor sitului (în special spre vest şi est), identificarea distribuţiei spaţiale, a caracteristicilor şi elementelor constitutive ale structurilor arheologice, cât şi recuperarea tuturor artefactelor şi ecofactelor descoperite, dată fiind natura sitului cercetat, anume o zonă de locuire (aşezare preistorică deschisă, nefortificată), afectată semnificativ în partea superioară a depunerilor arheologice de intervenţii antropice moderne. Astfel obiectivul principal al colectivului de cercetare arheologică a vizat cercetarea exhaustivă a tuturor vestigiilor delimitate în zona afectată direct de lucrările de construire a autostrăzii, dar şi identificarea altor zone cu potenţial arheologic situate în imediata vecinătate - dar în afara - traseului acesteia.

Principalele constrângeri existente cu privire la derularea cercetărilor arheologice preventive au fost determinate de actualizarea pe parcurs a proiectului tehnic de construire a autostrăzii (iniţial limita de expropriere pentru construirea autostrăzii nefiind materializată în teren), condiţiile meteo (perioade de caniculă), calendarul de lucrări arheologice pe acest tronson ${ }^{32}$ şi termenele de lucru.

${ }^{31}$ Vezi supra n. 30.

${ }^{32}$ Este de remarcat faptul că echipa de arheologi care a efectuat săpături arheologice preventive in cadrul sitului Aurel Vlaicu - Obreaza (denumit și sit 2 în cadrul lucrărilor de diagnostic a potenţialului arheologic de-a lungul lotului nr. 1 al autostrăzii Orăștie - Sibiu) a fost implicată anterior, în perioada martie - iulie 2012, în cercetarea unui alt sit 
Desigur, odată cu finalizarea cercetării arheologice în teren, cel mai important demers îl reprezintă procesarea datelor post-săpătură, a datelor referitoare la vestigiile arheologice cercetate ${ }^{33}$, precum şi conservarea-restaurarea ${ }^{34}$ şi inventarierea bunurilor arheologice mobile. Datã fiind amploarea cercetărilor în teren şi natura sitului, cantitatea de material arheologic rezultată este destul de mare. Ori, în conformitate cu principiile şi practicile ce definesc o cercetare arheologică, obiectivele strategice referitoare la salvgardarea patrimoniului arheologic în contextul unei abordări de tip ,păstrare prin înregistrare” sunt atinse numai prin derularea adecvată a unor asemenea activităţi, care vizează evidenţa patrimoniului arheologic mobil (inclusiv clasarea unora dintre bunurile descoperite) şi valorificarea rezultatelor cercetărilor, în special prin publicarea acestora (prin articole, studii sau chiar volume cu caracter monografic). Deși au aproape doi ani de la încheierea cercetărilor arheologice preventive de la Aurel Vlaicu - Obreza, etapa de procesare post-săpătură a datelor şi materialelor arheologice s-a putut desfășura în ritm susținut datorită faptul că încă din toamna anului 2012 a putut fi formată o echipă care să gestioneze adecvat aceste descoperiri.

Din păcate, în ceea ce privește gestionarea per ansamblu a proiectelor de cercetare arheologică preventivă de amploare din România desfasşurate în ultimii 15 ani este mult prea puțin acordată importanța cuvenită - în termeni de timp şi resurse alocate, deopotrivă umane și financiare - acestei etape fundamentale a procesării post-săpătură, care reprezintă chiar esența unei strategii eficiente de protejare a patrimoniului arheologic prin demersuri de tip „salvgardare prin înregistrare/studiu"35. Acest fapt se datorează, pe de o parte, subestimării a priori a importanței şi complexității descoperirilor care pot să survină cu prilejul unor asemenea săpături de mari dimensiuni (determinate de însăşi caracteristicile proiectelor de dezvoltare a infrastructurii rutiere), iar pe de alta imobilismului și neacceptării reformării sistemului bugetelor instituțiilor publice (în special muzee) în sensul unor planificări multianuale (existente la nivel Uniunii Europene), respectiv al abordării proiectelor de arheologie preventivă de către conducerea unora dintre aceste instituții ca fiind surse majore de completare a alocațiilor bugetare tot mai reduse asigurate de administrația centrală (ministerele de resort). Astfel, se ajunge adesea ca proiectele de arheologie preventivă derulate în România - în ultimul deceniu și jumătate - să prevaleze din rațiuni pecuniare, pierzându-se din vedere - la nivel general - potențialul lor evident de a îmbogăți patrimoniul colecțiilor muzeale şi de a aduce noi date şi cunoştințe despre trecutul mai apropiat sau mai îndepărtat; astfel, sensul şi rolul arheologiei preventive ${ }^{36}$ în ansamblul ei sunt diluate şi deturnate, aceasta devenind - destul de frecvent - doar suma unor recuperări de material arheologic şi sursă de venit suplimentară la nivel instituțional. Deopotrivă sunt ignorate - în multe cazuri responsabilităţile pe care instituțiile organizatoare ale unor asemenea cercetări le au prin lege față

preistoric situat pe traseul aceluiaşi tronson al autostrăzii, între km 14+100-14+500, sit hallstatian cunoscut astăzi sub denumirea Tărtăria - Podu Tărtăriei vest.

${ }^{33}$ Procesarea post-sãpătură a datelor şi materialelor arheologice este, în chip firesc, un demers colectiv, realizat după cum urmează: organizarea și digitizarea arhivei documentare de cercetare \& baza de date - Corina Borş, Luciana RumegaIrimuş, Vlad Rumega-Irimuş; topografie arheologică şi cartări - Vlad Rumega-lrimuş; triere material ceramic Luciana Rumega-Irimuş, Vlad Rumega-Irimuş, Marius Streinu (trim. I/2013), Mihaela Golea (trim. I/2013); studiu ceramică - Corina Borş, Luciana Rumega-Irimuș; studiu piese de metal - Corina Borş; evidență materiale arheologice - Corina Borș, Vlad Rumega-Irimuş, Marius Streinu (trim. I/2013), Mihaela Golea (trim. I/2013); desen material arheologic - Simona Movilă, Luciana Rumega-Irimuș, Sebastian Dobrotă (trim. IV/2012); fotografii piese arheologice - Luciana Rumega-Irimuș, Vlad Rumega-Irimuș.

${ }^{34}$ Dorim și pe această cale să mulțumim în mod deosebit doamnelor Gabriela Dragomir și Ileana Zahariade - restauratori ceramică, domnilor Francisc Dozsa și Alexandru Dozsa - restauratori metal şi mai tinerilor lor colaboratori: Mădălina Voicu, Radu Bălānescu, Mihai Duca și Paul Popa pentru activitatea lor desfăşurată în legătură cu restaurarea lotului de material arheologic provenit din situl Aurel Vlaicu - Obreza.

${ }^{35}$ Vezi în acest sens definiția noțiunilor de ,preservation by record", utilizată în mediul arheologic anglo-saxon, respectiv cea de „sauvegarder par l'étude”, cu care se operează în cazul arheologiei preventive din Franța; Borș 2014, 90-105, cu bibliografia străină de referință. În primul rând, arheologia preventivă trebuie înțeleasă ca fiind un demers responsabil, ce implică o multitudine de competențe și responsabilități; vezi în acest sens o recentă sinteză asupra mai multor puncte de vedere referitoare la arheologia preventivă din Franța, Aubin, Mandy 2014.

${ }^{36}$ Aubin 2014, 15-25 
de gestionarea - în bune condiții și conform standardelor de bună practică uzuale la nivel european ${ }^{37}$ - a bunurilor de patrimoniu arheologic astfel descoperite, respectiv restaurarea şi conservarea acestora, urmate de valorificarea lor din punct de vedere ştiințific și muzeal, dar şi în interes public.

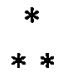

Pentru a obţine o imagine cât mai pertinentă referitoare la stratigrafia generală a sitului de la Aurel Vlaicu - Obreza, prima fază a cercetării arheologice preventive a vizat deschiderea a cinci secţiuni magistrale (identificate cu siglele $\mathrm{S}_{001}-\mathrm{S}_{005}$ ) situate - aproximativ - de-a lungul axului median al autostrăzii. De asemenea, pentru delimitarea certă a sitului au fost deschise o serie de suprafețe de cercetare (identificate cu siglele $\mathrm{S}_{\mathrm{I}}, \mathrm{S}_{\mathrm{II}}, \mathrm{S}_{\mathrm{III}}, \mathrm{S}_{\mathrm{VI}}, \mathrm{S}_{\mathrm{VII}}$ și $\mathrm{S}_{\mathrm{XI}}$ ). Astfel a putut fi clar stabilită absența oricăror structuri arheologice în partea vestică a zonei de interes, anume aproximativ între $\mathrm{km} \mathrm{4+860} \mathrm{şi} \mathrm{5+020} \mathrm{(PI.} \mathrm{V-VI).} \mathrm{Pe} \mathrm{cale} \mathrm{de} \mathrm{consecinţă,} \mathrm{datele} \mathrm{obţinute} \mathrm{prin}$ diagnosticul de teren din toamna anului 2011 și prima etapă a cercetării din campania 2012 (a doua jumătate a lunii iulie) au putut fi coroborate mai exact, indicând în mod evident o concentrare a locuirii preistorice în zona estică a sitului, către pantele de nord-est şi est ale platoului pe care acesta este situat. Foarte probabil locuirea preistorică va fi existat şi la est de km $5+150$, dar această zonă a fost anterior (înainte de începerea cercetărilor arheologice preventive) afectată de sistemele de irigaţii şi lucrările de amenajare a şantierului de construire a autostrăzii.

Într-o a doua etapă, pornind de la observaţiile preliminare efectuate pe profilele longitudinale ale secţiunilor magistrale $S_{004}$ și $S_{005}$, strategia de săpătură a vizat deschiderea unor noi suprafeţe de cercetare (identificate cu siglele $\mathrm{S}_{\mathrm{IV}}, \mathrm{S}_{\mathrm{V}}, \mathrm{S}_{\mathrm{VIII}}, \mathrm{S}_{\mathrm{IX}}, \mathrm{S}_{\mathrm{X}}$ ) pentru identificarea şi delimitarea complexelor arheologice. Stratigrafia generală a sitului a fost completată cu o serie de observaţii efectuate pe profilele transversale ale suprafețelor de cercetare situate între km 5+020 şi $\mathrm{km} 5+150$, de o parte şi de alta a axului autostrăzii. Au putut fi astfel înregistrate o serie de observaţii de detaliu în ceea ce priveşte stratigrafia sitului în zona cu concentraţie maximă de vestigii arheologice.

Tinând cont de situaţia existentă în teren, săpăturile arheologice au fost organizate printr-o cercetare în suprafaţă (open area excavation), într-o abordare metodologică adaptată unei serii întregi de factori. Pe întreaga porţiune cercetată din situl Aurel Vlaicu - Obreza, datorită termenelor contractuale, dar ţinând seama şi de observaţiile stratigrafice, decaparea s-a efectuat mecanic utilizând trei excavatoare, toate prevăzute cu cupă lisă (de taluz), fapt care a permis obţinerea unor răzuieli cu acuratețe suficientă pentru a identifica și delimita complexele. Având în vedere observațiile realizate în secțiunile magistrale de sondaj, a fost decapată întreaga suprafată a sitului aflată pe traseul autostrăzii până la limita nordică de expropriere, păstrând diverşi martori stratigrafici, ulterior demontaţi, care separau iniţial suprafețele de cercetare.

În general, contextele au fost delimitate mai ales către limita dintre stratul de sol negru şi depunerea de argilă galbenă. De remarcat faptul că în puține cazuri complexele se conturau imediat sub stratul vegetal, dată fiind perturbarea generală de plantarea şi, ulterior, dezafectarea livezii. În stratul negru, în lipsa materialului sau lentilelor de cenuşă sau de argilă din umplutură, a fost destul de dificil să poată fi delimitată forma gropilor. S-au conturat astfel așa-numite resturi de strat de cultură, unde existau concentrări de material ceramic fragmentar, acestea fiind săpate manual. Stratul vegetal, având grosimi diferite în diverse porțiuni ale sitului, a fost decapat exclusiv cu mijloace mecanice. S-a încercat - pe cât posibil - reducerea perioadei dintre identificarea complexelor în urma decapării mecanice şi cercetarea lor propriu-zisă. Astfel, toate complexele/contextele arheologice identificate au fost săpate manual, cu efectuarea ritmică a observaţiilor şi înregistrărilor arheologice şi topografice. Metoda folosită pentru delimitarea complexelor a constat în serii de răzuieli succesive realizate manual, care au urmat decapării solului vegetal actual cu mijloace mecanice, sub strictă supraveghere arheologică. 
După delimitare, complexele au fost identificate cu siglă de complex şi au fost descrise preliminar. Odată conturate, complexele au fost mai întâi fotografiate, apoi desenate la scara 1/20, cu excepţia unor detalii precum dispunerea obiectelor în umplutura unor gropi, care au fost înregistrate la scara 1/10. În acelaşi timp, localizarea complexelor a fost înregistrată cu staţia totală, datele fiind ulterior integrate în planul general de către un arheolog din echipa de cercetare ${ }^{38} ; \mathrm{s}-\mathrm{a}$ încercat, pe cât posibil, asigurarea unui schimb constant de date cu echipa topografică pusă la dispoziție de către Beneficiar. Etapa următoare a cercetării a constat în secţionarea complexelor. Pe întreaga suprafał̧ă cercetată a sitului au fost descoperite mai multe tipuri de complexe, aparţinând habitatului preistoric: posibile bordeie/locuinţe semi-adâncite (poate mai corect spus construcţii semi-adâncite), gropi menajere (structuri de tip refuse pit), gropi de provizii şi gropi fără funcţionalitate certă. S-a încercat, pe cât posibil ca gropile să fie secţionate de-a lungul diametrului maxim; în general, s-a urmărit săparea lor pe contur. După înregistrarea prin fotografiere şi desen a profilului, s-a procedat la săparea celeilalte jumătăţi a gropilor.

Pentru gestionarea eficientă a datelor, inclusiv pentru introducerea acestora în proiectul GIS, au fost utilizate - încă de la începerea săpăturii - fişe standard pentru unitățile de săpătură, complexe arheologice şi material special (vase întregi/întregibile, piese de metal, piatră prelucrată etc.). De asemenea, în ceea ce priveşte modalitatea de înregistrare a informaţiilor, au fost folosite metode descriptive uzuale în arheologie, texte descriptive, desene - grund şi profil, fotografii, măsurători altimetrice şi topografice etc. Astfel, au fost realizate planuri şi profile (generale şi de detaliu), cât şi fotografii în format digital pentru diferitele stadii de cercetare ale complexelor (conturare/secţionare/finalizare).

Tinând cont de toate acestea, la încheierea cercetărilor de teren - desfăşurate pe o perioadă de aproximativ o lună și jumătate acoperind o suprafaţă de aproximativ 1,75 ha, din care circa 1 ha reprezentând săpătură arheologică în suprafaţă deschisă - s-a trecut la următoarea etapă, anume cea a procesării post-săpătură a datelor şi materialelor arheologice.

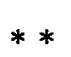

Cercetarea arheologică în general, şi cu atât mai mult cea preventivă de amploare, necesită gestionarea și documentarea cu acuratețe şi precizie, într-un mod standardizat, a datelor înregistrate în teren; acestea cuprind descrierea complexelor/structurilor/contextelor arheologice, documentarea fotografică a acestora şi întocmirea unor planuri şi hărți care să ilustreze cât mai corect situația din teren ${ }^{39}$. Cartarea (transpunerea prin simboluri grafice şi prin culori convenționale, pe hărți topografice) reprezintă cea mai fidelă și precisă modalitate de înregistrare a datelor spațiale ${ }^{40}$, devenind tot mai accesibilă și utilizată în domeniul arheologiei în ultimele decenii. Întregul demers este facilitat de utilizarea Sistemelor Informaționale Geografice ${ }^{41}$ (Geographical Information System - GIS), care permit introducerea, arhivarea, gestionarea și analiza unor informații raportate la coordonate geografice, cu ajutorul calculatorului. Un mare beneficiu al acestei aplicaţii îl reprezintă posibilitatea de a actualiza constant baza de date asociată, păstrând atât informațiile vechi, cât şi cele noi.

Odată cu începerea săpăturilor arheologice din situl Aurel Vlaicu - Obreza, o echipă topografică, pusă la dispoziție de către Beneficiar, a efectuat toate ridicările topo în cadrul sitului menționat, ca mai apoi să poată fi integrate toate informațiile înregistrate, pentru procesarea datelor post-săpătură într-o manieră accesibilă și bine organizată. Obiectivul principal al acestui demers a vizat înregistrarea în Proiecția Stereografică 1970 (Stereo 70) a tuturor unităților de săpătură (secțiuni magistrale, suprafețe de cercetare) și a structurilor arheologice investigate utilizând o stație totală, conform cerințelor formulate de arheologii din cadrul echipei de cercetare în teren. Încă de la bun început, echipa de arheologi și echipa de topografi a Beneficiarului, au agreat

\footnotetext{
${ }^{38}$ Este de remarcat faptul că echipa de cercetare a sitului Aurel Vlaicu - Obreza a avut un atu deosebit prin expertiza domnului Vlad Rumega-Irimuş în domeniul topografiei arheologice.

${ }^{39}$ Drewett 2011, 54

${ }^{40}$ Renfrew, Bahn 2008, 90

${ }^{41}$ Renfrew, Bahn 2008, 92-95; Westcott, Brandon 2000, 1-2; Drewett 2011, 54-68
} 
modalitatea de înregistrare şi schimb de date. Astfel, datele au fost măsurate constat, la intervale de aproximativ 3-4 zile (cu excepția primei săptămâni de săpătură), coroborat cu predarea rezultatelor brute către echipa de arheologi în săptămâna imediat următoare efectuării măsurătorilor. În cadrul echipei arheologice, responsabilul științific al şantierului a desemnat - ținând cont de competența în domeniu - un arheolog care a asigurat verificarea şi integrarea datelor ${ }^{42}$. Într-o primã fază s-au înregistrat doar unitățile de săpătură (secțiuni magistrale și suprafețe de cercetare), pentru ca odată cu dezvoltarea în suprafață a săpturii să fie înregistrate şi complexele/contextele arheologice. În privința complexelor și a materialul special, s-a avut în vedere colectarea datelor într-o manieră cât mai accesibilă și inteligibilă. Astfel, pentru înregistrarea precisă a conturului complexelor investigate s-au înregistrat de la 2 până la 4 puncte $^{43}$, iar pentru materialul special câte unul. Toate datele obținute, prelucrate şi interpretare, au fost suprapuse pe diverse suporturi cartografice, precum aşa-numitele „hărți austriece” $\left(1910\right.$, scara 1:200.000) ${ }^{44}$, Planurile directoare de tragere (perioada interbelică, scara $1: 100.000)^{45}$, hărțile sovietice (perioada comunistă, scara 1:50.000 și $1: 100.000)^{46}$, Harta Geologică a României (mijlocul anilor '60, scara 1:200.000) ${ }^{47}$ şi, într-o anumită măsură, pe ortofotoplanuri (furnizate de Beneficiar), pentru a urmări evoluția în timp a peisajului și construcțiile care ar fi putut afecta situl de-a lungul anilor.

\section{DATE PRIVIND STRATIGRAFIA GENERALĂ A SITULUI}

Referitor la porțiunea investigată din situl Aurel Vlaicu - Obreza, în campania arheologică a anului 2012, a putut fi stabilită următoarea succesiune stratigrafică:

- primul nivel (de la suprafaţa actuală de călcare), este reprezentat de solul vegetal identificat prin sigla (1) ${ }^{48}$; acesta diferă de la o zonă la alta a sitului fiind nivelul cel mai puternic afectat de intervenţiile antropice contemporane (livada de pomi fructiferi, lucrările agricole moderne etc.); acesta a fost observat între cota 0 (nivelul actual de călcare) şi adâncimea de $0,10 \mathrm{~m}$ și până la $-0,40 \mathrm{~m}$, variind în diversele porţiuni ale sitului; pe toată suprafał̧a sitului, în acest nivel s-au observat fragmente ceramice, oase şi chirpici amestecate, dar şi multe rădăcini de pomi în urma defrişării zonei; materialele arheologice (în special ceramica) datează din diverse epoci istorice (preistorie - epoca bronzului şi până în perioada medievală - fragmente de ceramică smălţuită, secolele XVI-XVII (?) şi chiar material modern); - cel de-al doilea nivel are o grosime constantă între 0,30 şi $0,40 \mathrm{~m}$, reprezentând un strat de pământ negru (2), compact, foarte uscat datorită pătrunderii aerului în spaţiile din care au fost extrase rădăcinile pomilor; a fost observat între $-0,10 /-0,40 \mathrm{~m}$ şi până la $-0,40 /-0,80 \mathrm{~m}$; acest

${ }^{42}$ Această decizie a fost luată pomind de la standardele de bună practică utilizate la nivel european în ceea ce privește desfâșurarea cercetărilor arheologice preventive, prin punerea în practică a principiului „salvgardării prin înregistrare”.

${ }^{43}$ Pentru exemplificare, modalitatea de lucru în cadrul cercetărilor arheologice preventive derulate în cadrul sitului Aurel Vlaicu - Obreza, a fost următoarea: în urma secționării unui complex a rezultat o axă A-B, care a fost folosită deopotrivă pentru desen şi ridicare topografică, caz în care punctele A şi B au fost măsurate de la nivelul de conturare și conțin coordonatele $\mathrm{x}, \mathrm{y}, \mathrm{z}$ (unde z reprezintă cota raportată la nivelul mării). Utilizând programul QuantumGIS (program open-source, care nu necesită licență), s-au încărcat punctele A, B, planul scanat al complexului și s-a procedat la georeferențierea celui din urmă (unde punctul A de pe desen corespunde cu punctul topografic A etc.). Digitizarea s-a făcut manual, pentru fiecare complex în parte (utilizând „layere” şi transpunerea cât mai fidelă în format digital a conturului complexului).

44 Resursă cartografică disponibilă on-line la http://earth.unibuc.ro/download/harile-austriece-1910-reproiectate-instereo70 (accesat la 09.06.2013)

${ }^{45}$ Resursă cartografică disponibilă on-line la http://earth.unibuc.ro/download/planurile-directoare-de-tragere (accesat la 09.06.2013)

46 Resursă cartografică disponibilă on-line la http://earth.unibuc.ro/download/hartile-sovietice-50k; http://earth.unibuc.ro/download/hartile-sovietice-1-100-000-reproiectate-in-stereo70 (accesat la 09.06.2013)

${ }^{47}$ Resursă cartografică disponibilă on-line la http://earth.unibuc.ro/download/harta-geologica-a-romaniei-scara-1-200-000 (accesat la 09.06.2013)

${ }^{48}$ Sigla (1) coincide cu numerotarea utilizată la legenda planşelor pentru profilele magistrale înregistrate pe latura nordică a suprafeței de cercetare identificate cu sigla $S_{\mathrm{V}}$, pe o lungime de circa $90-100 \mathrm{~m}$; similar pentru siglele utilizate pentru nivelurile (2), (3) şi (4). 
nivel este neuniform pigmentat cu chirpici şi conţine o cantitate mare de material arheologic, atât din perioada preistorică/antică, dar şi din epoci mai recente;

- cel de-al treilea nivel este reprezentat de resturile stratului de cultură (preistoric), în acest context (3) fiind identificate, la diferite adâncimi sau chiar la baza sa majoritatea complexelor arheologice; acest strat are o grosime de aproximativ $0,30 \mathrm{~m}$ în părţile de vest şi de est ale sitului, în vreme ce între $\mathrm{km} 5+040$ şi $5+085 / 5+090 \mathrm{~s}$-a observat o alveolare accentuată (viroagă?), care pe alocuri atinge adâncimea de $1,80 \mathrm{~m}$ de la nivelul actual de călcare, având circa $1 \mathrm{~m}$ grosime; este caracterizat de un sol brun-cenuşiu, amestecat cu chirpici, cărbune şi cenuşă (3), dar cu mai puţin material arheologic comparativ cu nivelul (2); în suprafata de cercetare $S_{V}$ unele complexe au apărut aproximativ la jumătatea acestui nivel, făcând destul de dificilă conturarea gropilor în contextul asemănării de culoare şi textură a umpluturilor gropilor cu stratul preistoric; chiar şi acest nivel este - în unele locuri - afectat de fosta livadă ce a existat aici, însă în mai mică măsură comparativ cu nivelurile (1) şi (2);

- ultimul nivel (4), steril din punct de vedere arheologic este constituit de un sol de culoare galbenă, care are o consistenţă diferită în funcţie de caracteristicile terenului; în jumătatea de est a sitului, acesta coincide cu un strat nativ de pietriş şi calcar, în vreme ce în partea centrală are o consistenţă nisipoasă, iar în partea de vest (unde complexele apar mult mai sus) este lutos; acest nivel s-a putut observat la adâncimi variind de la $0,80 \mathrm{~m}$ până la $2,00 \mathrm{~m}$ de la nivelul actual.

Aşa cum s-a menţionat anterior, profilele longitudinale ale secţiunilor magistrale şi ale suprafețelor de cercetare deschise au permis observarea a trei straturi, de grosimi variabile, în funcţie de configuraţia terenului. Având în vedere diversitatea lor pe întreaga suprafaţă a sitului, a fost ales pentru exemplificare profilul nordic al suprafeței de cercetare $\mathrm{S}_{\mathrm{IX}}$, pornind de la $\mathrm{km} 5+020$ şi până la km 5+114, totalizând 94 de metri liniari (Pl. VII).

Date fiind caracteristicile sitului (stabilite odată cu deschiderea secţiunilor magistrale $\mathrm{S}_{003}$ $\mathrm{S}_{005}$ pe direcţia V-E), timpul (circa şase săptămâni, program de lucru de șase zile pe săptămână, 10 ore zilnic) şi logistica avută la dispoziţie (echipă de muncitori cu un efectiv mediu de circa 30-35 persoane, trei excavatoare cu cupă de taluz lată şi trei camioane) s-a optat pentru efectuarea decapării exclusiv cu mijloace mecanice (pe direcţia $\mathrm{E}-\mathrm{V}$, mai întâi în zona situată la sud de axul autostrăzii şi apoi în cea situată la nord de acesta). De asemenea, cunoscând faptul că situl a fost afectat anterior de existenţa livezii şi a sistemului de irigaţie, s-a optat pentru decaparea nivelului (2) - vezi mai jos detalii - tot cu mijloace mecanice, sub strictă supraveghere arheologică.

Astfel a fost posibil ca - în timpul avut la dispoziţie şi cu logistica existentă - nivelul (3) vezi mai jos detalii - şi complexele arheologice să fie săpate manual, până la nivelul solului viu. De asemenea, în aceste condiţii a fost posibilă extinderea cercetării în partea de nord şi nord-est a sitului, cu circa 15-20 m faţă de expropriere propriu-zisă, între km 5+020 şi 5+150. Astfel, toate complexele/contextele arheologice identificate au fost săpate manual, cu efectuarea ritmică a observaţiilor şi înregistrărilor arheologice. Metoda folosită pentru delimitarea complexelor a constat în serii de răzuieli succesive, care au urmat decapării nivelurilor (1) şi (2) cu mijloace mecanice, sub strictă supraveghere arheologică.

\section{SCURTÃ PREZENTARE A DESCOPERIRILOR ARHEOLOGICE}

Într-o descriere preliminară succintă, descoperirile arheologice provenite din cadrul sitului de la Aurel Vlaicu - Obreza aparţin unei locuiri/aşezări preistorice deschise. Absenţa unor elemente constructive de tipul pereţilor, podinelor, vetrelor etc. in situ în majoritatea complexelor cercetate ne fac să fim rezervaţi - cel puţin pentru moment - în stabilirea funcţionalităţii certe a structurilor investigate, cu o serie de excepţii care vor fi prezentate mai jos. Este de remarcat numărul destul de redus al materialelor ceramice din inventarul complexelor, dar și gradul mare de fragmentaritate al acestora. În egală măsură trebuie menţionat faptul că a fost descoperită - atât în strat, cât şi în inventarul gropilor - o cantitate relativ mare de oase de animal. Coroborarea acestor aspecte constituie unul din temeiurile care susțin ipoteză că situl de Aurel Vlaicu - Obreza este o stațiune 
arheologică ce se adaugă repertoriului de descoperiri al culturii Noua. Alţi doi factori de natură să determine o abordare prudentă în ceea ce priveşte încadrarea cronologică a sitului şi funcţionalitatea complexelor cercetate sunt gradul mare de perturbare antropică contemporană a depunerilor arheologice superioare şi stadiul preliminar al procesării post-săpătură a materialului.

Totuşi, în stadiul actual de analiză a materialului arheologic descoperit pot fi formulate consideraţii preliminare asupra categoriilor funcţionale ale structurilor cercetate. Astfel, per ansamblu complexele arheologice cercetate se încadrează în următoarele categorii: bordeie/locuinţe adâncite, gropi menajere (structuri de tip refuse pit), gropi de provizii şi gropi fără funcţionalitate certă (unele dintre acestea putând fi simple gropi de lut), respectiv rest de strat de cultură.

Este de remarcat cantitatea relativ importantă de material osteologic faunistic prelevat din inventarul complexelor, respectiv pentru 90 dintre acestea dintr-un total de 133 de complexe/contexte cercetate. Altfel spus $67,66 \%$ sau $2 / 3$ dintre complexele investigate au furnizat probe osteologice, acestea fiind în prezent în curs de analiză şi determinare pentru elaborarea unui studiu arheozoologic ${ }^{49}$.

Cercetarea arheologică efectuată în perioada iulie - august 2012 pe traseul autostrăzii Al: Orăștie - Sibiu, în raza satului Aurel Vlaicu (com. Geoagiu, jud. Hunedoara), punct Obreza, a condus la investigarea completă a zonei sitului arheologic Al - OS1/ sit $2(\mathrm{~km} \mathrm{4+900-5+150)}$ afectată de lucrările de construire a autostrăzii $\mathrm{Al}$, respectiv a unei porţiuni situate la nord de aceasta, astfel fiind delimitate şi cercetate 133 complexe arheologice. În condiţiile şi circumstanţele prezentate a fost cercetat integral tot perimetrul care urma să fie afectat de lucrările de construire ale autostrăzii Orăștie - Sibiu. Analiza distribuţiei spaţiale a complexelor arheologice şi observaţiile stratigrafice indică în mod cert că situl este numai parţial afectat de construirea autostrăzii, astfel că la nord şi sud de traseul acesteia rămân porţiuni care vor putea fi investigate prin cercetări arheologice cu caracter sistematic (PI. VI, XXV, XXVI).

Cercetarea arheologică preventivă a confirmat numai parţial datele preliminare obţinute prin studiile de diagnostic arheologic (teoretic şi de teren) din anii 2008 şi 2011 . Astfel, în cazul de faţă este vorba despre un sit cu un singur nivel de locuire (şi nu pluristratificat aşa cum s-a considerat anterior, în momentul redactării raportului de diagnostic), depunerea arheologică fiind semnificativ perturbată de intervenţii antropice recente (o fostă livadă şi un sistem de irigaţii cu elemente subterane); observaţiile stratigrafice și materialul arheologic descoperit (preponderent ceramică) nu susţin ipoteza, formulată prin studiul de diagnostic din toamna anului 2011, conform căruia situl ar fi unul pluristratificat, cu niveluri de locuire aparținând sfârșitului epocii bronzului şi perioadei timpurii a primei epoci a fierului ${ }^{50}$. Recunoașterea pe teren efectuată la nord și sud de traseul viitoarei autostrăzi, pe de o parte în zona dintre traseul autostrăzii Al şi actualul traseu al lui DN7, respectiv zona livezii şi terenurilor agricole aflate la sud de traseul autostrăzii, coroborate cu observaţiile stratigrafice şi planul general al descoperirilor din porţiunea cercetată a sitului au oferit indicii semnificative privind faptul că vestigiile staţiunii preistorice de la Aurel Vlaicu - Obreza există și în afara perimetrului investigat prin cercetări arheologice preventive de amploare în vara anului 2012.
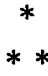

În continuare, ținând cont de amploarea descoperirilor arheologice efectuate în cuprinsul sitului Aurel Vlaicu-Obreza, cât şi de stadiul preliminar al analizei post-săpătură a datelor şi materialelor arheologice, respectiv al restaurării loturilor de ceramică și piese din metal sunt prezentate preliminar, pentru exemplificare, o serie de date cu privire la unele complexe arheologice.

\footnotetext{
${ }^{49}$ Studiul arhezoologic al materialului faunistic provenit din situl Aurel Vlaicu - Obreza este în desfășurare, fiind realizat de către dr. Adrian Bălăşescu şi dr. Valentin Radu, din cadrul Secţiei de Investigaţii a Muzeului Naţional de Istorie a Românei, cărora le mulțumim și pe această cale pentru demersul lor.

${ }^{50}$ Vezi supra $\mathrm{n} .30$.
} 


\section{XXXIB/1-2)}

Complexul 012 (dimensiuni: $\mathrm{D}_{\max }=2,80 \mathrm{~m}$; ad. = 1,00 $\left.\mathrm{m}^{51}\right)(\mathbf{P I} . \mathbf{I X}, \mathbf{X V I I} / \mathbf{2}-\mathbf{3}, \mathbf{X X X I A} / 4$,

Complex de mari dimensiuni care s-a conturat sub forma unei pete cenuşii (relativ circulară) după decaparea stratului vegetal. Umplutura gropii constă din pământ cenuşiu, cu consistenţă făinoasă (prăfoasă, pulverulentă), mai multe lentile de cenuşă, urme de chirpici şi cărbune, mai multe pietre. La bază se află un strat de pământ brun-cenuşiu, uşor mai compact decât restul umpluturii, amestecat cu galben şi cenuşă. Probabil iniţial aceasta a fost o locuinţă adâncită (bordei), păstrându-se o nişă cruţată în pământ de jur-împrejurul gropii, la circa $0,20 / 0,30 \mathrm{~m}$ adâncime faţă de nivelul de conturare. Ulterior va fi fost incendiată şi re-utilizată ca groapă menajeră. Au fost descoperite numeroase fragmente ceramice (unele tipice), bucăţi de lipitură, un fragment de râşniţă, scoici şi oase de animal. De remarcat asocierea de material ceramic de tip Noua (toartă cu buton) cu material ceramic cu decor canelat.

Complexul 017 (dimensiuni: $2,90 \times 2,50 \mathrm{~m}$; ad. = 1,20 m) (PI. X, XXVII/6)

Acest complex de mari dimensiuni care s-a conturat ca o pată aproximativ circulară de culoare brun-cenuşie. Date fiind caracteristicile, este probabil ca această groapă să fi fost o locuinţă adâncită, având mai multe trepte la jumătatea adâncimii sale pe laturile de NV şi SE. Pornind de la nivelul inferior al „treptelor”, groapa se cuptorea puternic de jur-împrejur. La bază groapa era umplută cu un strat de pământ brun-cenuşiu, uşor compact, amestecat cu lentile de galben şi calcar, dar fără alţi pigmenţi. Ulterior groapa pare să fi fost utilizată ca groapă menajeră, umplutura sa în partea superioară constând din pământ de culoare cenuşie, cu consistenţă fãinoasă (prăfoasă, pulverulentă), cu mai multe lentile de galben (colmatări) pe margini și mai multă cenuşă spre bază. Din inventarul acestui context fac parte numeroase fragmente ceramice (între care şi câteva fragmente cu decor tipic, posibil aparținând fazei târzii a grupului Balta Sărată ?), lipitură de chirpici şi oase de animale, atât arse cât şi nearse.

Complexul 019 (dimensiuni: 1,80 × 1,40 m; ad. = 0,60 m) (PI. XI)

Latura de NV a complexului a fost vizibilă iniţial în sondajul S004, respectiv pe profilul de sud al acestuia fiind vizibile, la circa $-0,40 \mathrm{~m}$ faţă de nivelul actual de călcare, mai multe bucăţi de lipitură (vatră/perete), dispuse compact într-un sol cenuşiu pigmentat cu urme de chirpici şi cărbune. La secţionarea complexului s-a putut observa că groapa avea formă ovală în plan şi aproximativ cilindrică în secţiune (având pereţii relativ verticali). Umplutura gropii constă într-un număr foarte mare de fragmente consistente de lipitură (unele cu impresiuni) de vatră sau bucăţi de pereţi (posibil de la o locuinţă sau un cuptor) provenind de la o structură dezafectată, ale cărei resturi au fost aruncate în mod deliberat. Astfel groapa poate fi considerată ca o groapă menajeră. De asemenea din umplutura gropii au mai fost recoltate câteva fragmente ceramice de mici dimensiuni, atipice, şi o lupă/turtă de bronz (?).

\section{XXXIA/12)}

Complexul 041 (dimensiuni: $2,40 \times 2,20 \mathrm{~m}$; ad. $=1,35 \mathrm{~m})(\mathbf{P l}$. XII, XXVIII/5,

Acest complex de mari dimensiuni s-a conturat ca o pată de formă circular neregulată, de culoare cenuşie, fiind observată distinct la nivelul solului galben, steril - nivel (4). Aproximativ la $0,80 \mathrm{~m}$ adâncime în partea de nord groapa are o treaptă. Cu circa $0,20 / 0,40 \mathrm{~m}$ mai jos de acest nivel interior, groapa se cuptorește uşor la bază având în partea sa inferioară un strat de pământ brun cenuşiu amestecat cu calcar, care însă nu mai conţine material arheologic (posibil strat natural ?). Umplutura gropii consta din pământ cenuşiu cu urme de chirpici şi cărbune, dar şi multiple lentile de pământ galben. Din inventarul complexului provin fragmente ceramice, mai multe bucăţi de chirpici/lutuială făţuită (dintre care unele cu amprente) şi oase de animal, nearse.

Complexul 045 (dimensiuni: $1,30 \times 0,98 \mathrm{~m}$; ad. $=0,15 / 0,20 \mathrm{~m}$ ) (PI. XIII)

La decapare solului vegetal, aproximativ la adâncimea de $0,30 / 0,40 \mathrm{~m}$ (de la nivelul actual de călcare) a apărut o aglomerare de oase de animale. După o curăţare preliminare s-a observat că este vorba de o masă relativ mare (compactă) de oase; acestea provin de la mai multe animale, unele parțial în conexiune anatomică, altele adunate în grămadă. La o primă impresie oasele par să fie resturi de faună sălbatică (animale vânate ?). Groapa în care acestea au fost depuse a fost observată destul de dificil, respectiv o groapă de mici dimensiuni cu formă ovală. Umplutura

\footnotetext{
${ }^{51}$ Adâncimile complexelor sunt indicate de la nivelul de conturare al acestora.
} 
acesteia consta din pământ negru compact, foarte bine tasat. Printre oasele de animal au mai fost descoperite destul de puţine fragmente ceramice (între acestea, de remarcat, un fragment de ceaşcă cu decor canelat, dispus în ghirlandă).

Complexul 048 (dimensiuni: $3,30 \times 3 \mathrm{~m}$; ad. $=1,40 \mathrm{~m})(\mathbf{P I} . \mathbf{X I V}, \mathbf{X X I X / 3 , X X X I A / 5 )}$

La decaparea cu mijloace mecanice a solului vegetal, la circa $-0,30 /-0,35 \mathrm{~m}$ faţă de nivelul actual de călcare, a putut fi observată o pată de mari dimensiuni, cu textură cenuşoasă (prăfoasă, pulverulentă) şi urme de arsură pe direcţia E-V (în legătură directă cu groapa). După secţionarea gropii, s-a putut stabili că aceasta pare să fi fost o locuinţă adâncită cu trepte pe mai multe laturi, pata de arsură fiind amprenta unei bârne incendiate, căzută spre exterior în partea de vest a complexului. Dimensiunile acesteia erau de $1,80 \mathrm{~m}$ lungime, lăţime maximă de $0,40 \mathrm{~m}$ şi o grosime de $0,10 \mathrm{~m}$. Ulterior locuinţa a fost incendiată şi reutilizată ca groapă menajeră. Umplutura gropii consta din pământ de culoare cenuşie, cu consistenţă fãinoasă (prăfoasă, pulverulentă), cu urme de chirpici şi cărbune. În partea inferioară şi pe margini s-au mai păstrat urme ale fostei locuinţe, reprezentate de o umplutură mai închisă la culoare cu mult cărbune şi multiple lentile de brungălbui. Inventarul gropii este unul aparte, constând din bucăţi de lipitură de chirpici (de perete ?) de dimensiuni mai mari (în partea de NV a gropii, la aproximativ $0,20 \mathrm{~m}$ adâncime de la conturare), o cantitate mare de fragmente ceramice (inclusiv vase parţial întregibile, fiind de remarcat asocierea dintre material tipic pentru cultura Noua şi fragmente ceramice cu decor canelat), oase de animal nearse, dar şi două lupe de bronz (găsite aproximativ la aceeaşi adâncime, în partea de NE a gropii).

\section{Complexul 051 (dimensiuni: $2,18 \times 1,98 \mathrm{~m}$; ad. $=1,20 \mathrm{~m})(\mathbf{P l} . \mathbf{X V}, \mathbf{X V I}, \mathbf{X X I X / 6}$, XXXIB/8-11)}

Acest complex de mari dimensiuni care s-a conturat împreună cu un alt complex asemănător (complexul 052), având o formă aproximativ circulară, cu pereţii de formă neregulată. În partea de sud şi de vest, pereţii gropii se cuptoresc puternic, iar pe latura de nord a fost vizibilă o treaptă. Umplutura gropii consta din pământ cenuşiu, cu consistenţă făinoasă (prăfoasă, pulverulentă), pigmentat cu multiple urme de chirpici şi cărbune. Pe alocuri apăreau lentile (de diferite dimensiuni) de cenuşă. În partea de vest, pe marginea gropii umplutura era uşor mai închisă la culoare, datorită cantităţii mai ridicate de urme de cărbune existentă aici. În inventarul gropii au fost descoperite numeroase fragmente ceramice (între acestea şi fragmente de vase de culoare neagră, cu suprafaţa lustruită și decorate cu caneluri), bucăți de chirpici/lutuială (cu sau fără amprente), cochilii şi oase de animal. Cel mai probabil funcţionalitatea complexului era de groapă menajeră (?).

Complexul 052 (dimensiuni: $\mathrm{D}_{\max }=1,90 \mathrm{~m}$; ad. $\left.=1,20 \mathrm{~m}\right)(\mathbf{P I} . \mathbf{X V}, \mathbf{X V I}, \mathbf{X X I X / 2})$

Groapă de formă circulară cu umplutură de culoare cenuşie, cu consistenţă fãinoasă (prăfoasă, pulverulentă), cu pigmenţi mărunţi de calcar, chirpici şi cărbune, întreruptă pe alocuri de lentile de cenuşă şi lut galben. La baza complexului se afla un strat de pământ negru-cenuşiu, puternic pigmentat cu cărbune. Pe latura de nord-vest groapa prezenta o uşoară alveolare, iar pe jumătatea de sud-sud-vest şi puţin înspre sud-est pereţii gropii se cuptoreau. De asemenea, în partea de nord-nord-vest a fost observată o mică treaptă. Din inventarul acestei gropi provin destul de puţine fragmente ceramice şi oase de animal nearse. Este de presupus că groapa a fost una de tip menajer (,refuse pit").

Complexul 055 (dimensiuni: 4,50 × 4 m; ad. = 0,70 m) (PI. XVII, XVIII, XXIX/5)

Groapa a fost observată ca o pată de formă circulară neregulată, fiind săpatã până în stratul nativ de pietriş - nivel (4). Nu s-au surprins urme de gropi de pari în interiorul sau exteriorul său, dar s-a putut observat că aceasta era în legătură cu un alt complex (complexul 056), situat imediat spre vest, intersectându-se cu acesta în partea sa inferioară, la nivelul stratului de pietriş natural. Nu s-au găsit urme de pereţi prăbuşiţi sau de lipitură de vatră/cuptor. Umplutura gropii consta din pământ de culoare brun-negricioasă, cu multiple lentile de galben, urme de chirpici şi cărbune. Pereţii gropii erau relativ verticali. În partea de vest şi nord-nord-vest, spre partea inferioară groapa se cuptorea, iar în jumătatea sudică a fost observatã o treaptã (putând fi de presupus în această parte o zonă de acces). Toate caracteristicile gropii oferă indicii pentru a interpreta această structură ca fiind o locuinţă semi-adâncită/adâncită (bordei). Structura observată imediat la vest de acesta (vezi 
infra) ar putea fi considerată ca o anexă a locuinței (groapă de provizii, ţinând cont şi de cele patru vase sparte pe loc). Observaţiile stratigrafice indică o contemporaneitate a celor două structuri. De asemenea, este de remarcat faptul că acest complex reprezintă cea mai estică locuință din porţiunea de aşezare cercetatā, situată în exteriorul (la est de) aliniamentul de gropi (din zona km 5+130 $5+135$, dispuse pe direcţia NV-SE) spre deosebire de alte structuri similare. O altă particularitate a acestei structuri este aceea că ea nu a fost incendiată ulterior şi reutilizată ca groapă menajeră. Din inventarul acestei gropi provine o cantitate medie de fragmente ceramice (între care părți din două vase întregibile), bucăţi de chirpici şi puţină lipitură, un corn de cerb neprelucrat şi alte oase de animal, nearse.

Complexul 056 (dimensiuni: 2,32 × 2,10 m; ad. =0,50 m) (Pl. XVII, XVIII)

Acest complex reprezintă probabil o anexă a complexului 055. Aşa cum s-a menţionat mai sus, complexele 055 şi 056 sunt părţi ale aceleiaşi structuri de locuit (?); complexul 056A fiind situată la VNV (groapa cu vase), iar complexul 056B înspre est (groapă simplă de provizii). Groapa din partea de VNV este mai puţin adâncă decât cea estică, având formă aproximativ circulară. Umplutura sa consta din pământ de culoare negru deschisă, cu pigment de chirpici. În interiorul său au fost descoperite in situ (aşezate direct pe fundul gropii), patru vase de provizii grupate, de diferite dimensiuni. Acestea erau situate după cum urmează: cel mai mare, dispus cu gura în jos, este un vas bitronconic (având pe diametrul maxim butoni-apucători), localizat în partea de NV a gropii; imediat la sud de acesta se aflau alte două vase bitronconice (de dimensiuni mai mici decât precedentul), ambele cu gâtul supraînălţat, aşezate pe o parte (gura fiind îndreptată spre primul vas); aceste două vase sunt decorate cu caneluri oblice dispuse pe diametrul maxim şi o serie de proeminenţe (apucători ?); cel de-al patrulea vas (aparent cel mai mic ca dimensiuni) era aşezat relativ separat de celelalte trei vase, la est de această grupare, în aceeași poziţie ca şi primul vas, respectiv cu gura în jos. Spre deosebire de primele două vase, care erau realizate din pastă semifină de culoare neagră-cenuşie, acesta era lucrat din pastă brun-cărămizie. În inventarul gropii complexului $056 \mathrm{~A} \mathrm{nu}$ au mai fost descoperite alte materiale arheologice în afara celor patru vase menţionate. La est de prima groapă (complexlul 056A), a fost observată o altă groapă conexă, probabil cu rol de păstrare a alimentelor (groapă de provizii propriu-zisă). Aceasta avea formă circulară, cu diametru de $1,10 \mathrm{~m}$, şi o adâncime maximă de $0,90 \mathrm{~m}$ de la nivelul de conturare; a fost săpată în stratul nativ de pietriş (probabil şi datorită caracteristicilor termice ale acestuia, asigurând temperatură favorabilă păstrării hranei). Groapa (complexlul 056B) se cuptorea de jur împrejur, iar în partea inferioară, spre est, era intersectată de locuinţa adâncită (complexul 055). Din inventarul acestei gropi provin câteva fragmente ceramice şi oase de animal.

Complexul 058 (dimensiuni: $\mathrm{D}_{\max }=1,20 \mathrm{~m}$; ad. $\left.=1,15 \mathrm{~m}\right)(\mathbf{P I}$. XIX)

Complexul a fost observat iniţial ca o pată de culoare neagră, cu pigmenţi de chirpici, de formă relativ circulară. În partea superioară a gropii, pereţii acesteia erau relativ verticali, iar de la jumătatea acesteia (aproximativ $-0,60 /-0,65 \mathrm{~m}$ de la nivelul de conturare) groapa se lărgea, având formă de clopot în partea inferioară. Aceasta a fost săpată până în stratul nativ de pietriș. În umplutura gropii au fost găsite foarte puţine fragmente ceramice (atipice) şi oase de animal. Date fiind caracteristicile sale, funcţionalitatea complexului pare a fi aceea de groapă de provizii.

Complexul 064 (dimensiuni: $2,20 \times 1,50 \mathrm{~m} / \mathrm{D}_{\max }=1,40 \mathrm{~m}$; ad. $\left.=0,50 \mathrm{~m} / 0,90 \mathrm{~m}\right)(\mathbf{P I}$.

$\mathbf{X X )}$

Acest complex este constituit din două gropi (complexele 064A şi 064B), având probabil funcţionalitate diferită. Astfel, în partea de NNV este situată o groapă de formă ovală (complexul 064A), ai cărei pereţi se cuptoresc. Umplutura acesteia consta din pământ cenuşiu, cu consistenţă făinoasă (prăfoasă, pulverulentă), amestecat cu pigmenţi de chirpici şi cărbune. Această groapă este intersectată de o a doua groapă (complexul 064B), situată în partea de SSE a complexului. Această a doua groapă avea formă circulară. Aceasta era umplută cu pământ negru compact, uşor pigmentat cu chirpici, iar în partea superioară cu un pământ mai deschis la culoare (cafeniu). Materialul arheologic din ambele gropi a fost recoltat împreună, respectiv fragmente ceramice (atipice) şi câteva oase de animal, nearse. Posibila funcţionalitate a complexului pare a fi aceea de groapă menajeră, inclusiv în cazul complexul 064A.

Complexul 069 (dimensiuni: 2,70 × 1,65 m; ad. = 0,70 m) (PI. XXI, XXX/3) 
Complexul a fost observat ca o pată de mari dimensiuni, de culoare cenuşie albicioasă. Groapa avea o formă ovală neregulată, în interiorul său fiind vizibile două trepte succesive, situate în partea sudică. De la nivelul acestora (aproximativ $-0,25 \mathrm{~m}$ de la cota de conturare), groapa se adâncea cu circa $0,50 \mathrm{~m}$, cuptorindu-se de jur împrejur. Umplutura consta din pământ de culoare cenuşie, cu pigmenţi de chirpici şi cărbune, cu consistenţă fãinoasă (prăfoasă, pulverulentă); în partea mai adâncă a gropii (aproximativ la $-0,50$ m adâncime de la cota de conturare) a fost observată o lentilă compactă de galben-cenuşiu. Inventarul complexului cuprinde fragmente ceramice lucrate cu mâna (între care resturi ale unui posibil vas întregibil), bucăţi de lipitură de chirpici, o mărgea de lut, un fragment de greutate din lut, o râş̧niţa şi oase de animal nearse.

Complexul 080 (dimensiuni: $\mathrm{D}_{\max }=1,95 \mathrm{~m}$; ad. $=0,55 \mathrm{~m}$ ) (Pl. XXII)

Complexul s-a conturat ca o pată de culoare cenuşiu-albicioasă, aparent în legătură cu o altă groapă, de dimensiuni mai mari, situată la vest de ea (complexul 081). Groapa avea o formă circulară neregulată, iar pe latura de nord-est a fost observată o treaptă. În partea de vest groapa era intersectată de complexul 81. Umplutura complexului consta din pământ de culoare cenuşie, amestecat cu foarte multă cenuşă, pigmentat cu urme de chirpici şi cărbune. Din inventarul gropii provin fragmente ceramice (atipice), bucăţi de lipitură şi oase de animal nearse. Caracteristicile complexului pledează pentru încadrarea sa în categoria gropilor menajere.

Complexul 081 (dimensiuni: $3,20 \times 3,10 \mathrm{~m}$; ad. = 0,90 m) (Pl. XXII, XXX/2)

Complexul a fost observat odată cu complexul 080, sub forma unei pete de mari dimensiuni, având formă circulară. Pereţii gropii erau uşor tronconici. Umplutura gropii consta din pământ cenuşiu, amestecat cu urme de chirpici şi cărbune şi câteva lentile de galben. În partea de est s-a observat intersectarea acesteia cu complexul 080, într-un nivel de pământ brun-gălbui cu puţină cenuşă. Din inventarul gropii provin fragmente ceramice (între care un vas grosier întregibil şi posibil o ceşcută întregibilă), bucăţi de lipitură, un fragment de râşniţă şi oase de animal, prelucrate şi neprelucrate.

Complexul 088 (dimensiuni: 4,30 × 3,40 m; ad. = 1,30 m) (PI. XXIII)

Complexul a apărut (în colţul de $\mathrm{NE}$ al suprafeței de cercetare $\mathrm{S}_{\mathrm{IX}}$ ) ca o pată de mari dimensiuni de culoare cenuşie. Date fiind dimensiunile sale, s-a recurs la casetarea martorilor din acest colţ al suprafeței de cercetare, groapa putând fi astfel mai bine conturată (extinderea complexului spre vest printr-o alveolare. Umplutura gropii consta din pământ de culoare cenușie, cu consistenţă făinoasă (prăfoasă, pulverulentă), cu urme de chirpici şi cărbune şi multe lentile de lut galben în partea inferioară. În interiorul structurii, au putut fi observate $2-3$ trepte în jumătatea de nord; pereţii gropii aveau formă neregulată. Alveolarea din partea de vest se adânceşte doar 0,30 $\mathrm{m}$ faţă de nivelul de conturare al gropii. Din inventarul gropii provin mai multe fragmente ceramice (posibil un vas grosier întregibil şi fragmente ceramice cu decor canelat), câteva bucăţi de lipitură de chirpici şi oase de animal, nearse. Cel mai probabil, complexul a avut iniţial funcţionalitatea de locuinţă adâncită (bordei), dar nu au mai putut fi surprinse gropi de pari nici în exterior, nici în interior, datorită perturbărilor antropice moderne în nivelurile (1) şi (2). Alveolarea din partea vestică ar putea reprezenta fie o zonă de acces, fie resturi ale unei anexe a locuinței (groapă de provizii).

\section{Complexul 110 (dimensiuni: 1,4 0× ?) (PI. XXIV)}

La aproximativ $0,50 \mathrm{~m}$ sub nivelul actual în stratul de cultură a apărut o aglomerare de lipitură şi chirpici. Partea estică a acestui context a fost afectată în timpul decapării cu mijloace mecanice. Este foarte probabil ca aceste bucăţi de lipitură şi chirpici să reprezinte resturi ale unui perete (incendiat ?) prăbuşit, având în vedere şi amprenta termică observată în solul de culoare neagră, compact. Nu s-a observat conturul unei gropi, iar limitele exacte ale acestei aglomerări nu au putut fi stabilite. Printre fragmentele de chirpici au apărut și câteva fragmente ceramice (atipice) şi oase de animal, nearse. 
Analiza preliminară a materialului arheologic descoperit (ceramică, piese de metal și resturi faunistice) arată faptul că, din punct de vedere cronologic, această staţiune preistorică se datează, foarte probabil, în perioada de la finalul epocii bronzului şi începutul celei a fierului (Bz $\mathrm{C} / \mathrm{D}$ - Ha $\mathrm{A}_{1}$, secolele XIV/XIII-XII a. Chr), fiind de subliniat asocierea unor elemente caracteristice culturii Noua (ca de exemplu toarte cu buton, omoplaţi crestaţi) (PI. XXXI/A, XXXV/2) cu materiale hallstattiene timpurii (precum cele din perioada timpurie a orizontului cu ceramică cu decor canelat) (PI. XXXI/B), atât în stratul de cultură (destul de perturbat însă de intervenţii antropice moderne), cât şi în cadrul unora dintre complexe.

În ceea ce privește contextul arheologic general al sitului, este de subliniat, încă o dată, faptul că nivelurile superioare ale depunerii arheologice şi configuraţia terenului au fost semnificativ perturbate de livada de pomi fructiferi și conductele de aducţiune ale sistemului de irigaţie care au existat aici în ultimele 3-4 decenii. Prin urmare încadrarea cronologică propusă având caracter de ipoteză de lucru, în contextul procesării preliminare post-săpătură a materialului arheologic - pentru acest sit se bazează, în special, pe asocierile de material din complexe (considerate ca fiind contexte certe) (PI. XXVI) şi nu pe materialul descoperit în nivelurile arheologice, anume nivelul (2) şi nivelul (3).

Există însă o serie date preliminare care indică faptul că situl de la Aurel Vlaicu - Obreza ar putea constitui una dintre cele mai vestice staţiuni arheologice în care este documentată existenţa unor materiale caracteristice ale culturii Noua $^{52}$, fapt ce trebuie coroborat cu o serie de indicii privind o evoluţie târzie a unor elemente tardive ale acestei culturi în zona vestică/sudvestică a Transilvaniei şi contemporaneitatea acestora cu elemente specifice perioadei Hallstattului timpuriu (inclusiv orizontul cu ceramică cu decor canelat) ${ }^{53}$. Prin urmare, chiar și în acest stadiu preliminar al analizei post-săpătură, situl de la Aurel Vlaicu - Obreza oferă argumente în sprijinul ipotezei formulate anterior de o serie de cercetători în domeniu referitoare la un anumit „,sincronism” între finalul culturii Noua (o eventuală fază a III-a) şi începuturile primei epoci a fierului (Hallstatt-ului timpuriu), caracterizate inclusiv prin ceramică canelată pentru spaţiul vestic şi sud-vestic al României ${ }^{54}$. Desigur, toate acestea reprezintă, pentru moment, numai ipoteze de lucru, care urmează să fie validate sau nu odată cu finalizarea procesării post-săpătură a materialelor şi datelor colectate cu prilejul cercetării unei părţi a sitului în discuție ${ }^{55}$, dar şi de alte cercetări viitoare în cadrul sitului arheologic Aurel Vlaicu - Obreza.

\section{BIBLIOGRAFIE}

*** 1980

*** 1982

Alexandrescu 1966

Andrieșescu 1912
Hunedoara. Monografie, București, 1980

Enciclopedia geografică a României, București, 1982

Alexandrina Alexandrescu, Die Bronzeschwerter aus Rumänien, Dacia N.S., 10, 1966, p. 117-190

I. Andrieșescu, Contribuţie la Dacia inainte de romani, Teză de doctorat la Facultatea de Litere şi Filosofie din Iaşi, Tipărită cu cheltuiala Fundaţiei Carol I și a Casei \$̧coalelor, Iaşi, 1912

\footnotetext{
${ }^{52}$ Florescu 1991, 101, nr. 394 (Petrești, jud. Alba); 118, nr. 488 (Sibişeni - Vințu de Jos, jud. Alba); 123, nr. 518 (Șoimuş, jud. Hunedoara); 126-127, nr. 534-535 (Tărtăria, jud. Alba); 142, nr. 595 (Vințu de Jos, jud. Alba). Este de remarcat că unul dintre cele mai vestice puncte cunoscute cu material tipic culturii Noua este cel de la Şoimuş (jud. Hunedoara); acestuia i se adaugă o serie de descoperiri din cuprinsul Culoarului Orăștiei, precum și din zona Alba lulia - Sebeș. De asemenea, pentru alte descoperiri de tip Noua în zona vestică a Transilvaniei, vezi Ciugudean 2010, 159-160.

${ }^{53}$ Petrescu-Dâmbovița 2001, 285; László 2001, 305-306, 308-309, 312-313; Ciugudean 2010, 163, 166-167; Popa, Totoianu 2010, 220, 243-244; Ciugudean 201 1, 72-73, 81; Ciugudean 2012, 232-234, 240; Dietrich 2014, 282-321

${ }^{54}$ Ciugudean 2010, 163-165, 172 (inclusiv cu bibliografia mai veche referitoare la această problematică), 184, fig. 4

${ }^{55}$ Publicarea monograficá a rezultatelor cercetărilor arheologice preventive efectuate în anul 2012 în cadrul sitului Aurel Vlaicu - Obreza este preconizată pentru finalul anului 2015, în cadrul seriei „Monografii” a Muzeului Național de Istorie a României.
} 
Andriţoiu 1979

Andriţoiu 1988-1991

Aubin 2014

Aubin, Mandy 2014

Berciu, Popa 1967

Blăjan 1989

Borș 2014

Borş et alii 2013

Bratu 2009

Ciugudean 2010

Ciugudean 2011

Ciugudean 2012

Damian et alii 2012

Dietrich 2014

Drewett 2010

Florescu 1991

Jacob 2014

László 2001

Legea nr. 2001-44/2001 (Franţa)
I. Andriţoiu, Contribuţii la repertoriul arheologic al judeţului Hunedoara, Sargetia, 14, 1979, p. 15-34

I. Andriţoiu, Istoricul şi stadiul actual al cercetărilor privind epoca bronzului în sud-vestul Transilvaniei, Sargetia, 21-24, 1988-1991, p. 25-31

G. Aubin, L'archéologie préventive, hier et aujourd'hui, în G. Aubin, B. Mandy (texts réunis par), L'archéologie preventive : une demarche responsible. Actes des Rencontres autour de l'archéologie preventive 2122 novembre 2012, Ministére de la Culture et de la Communication. Direction générale des patrimonies - sous-direction de l'archéologie, Paris, 2014, p. 15-25

G. Aubin, B. Mandy (texts réunis par), L'archéologie preventive : une demarche responsible. Actes des Rencontres autour de l'archéologie preventive 21-22 novembre 2012, Ministére de la Culture et de la Communication. Direction générale des patrimonies - sous-direction de l'archéologie, Paris, 2014

I. Berciu, Al. Popa, Depozitele de bronzuri de la Zlatna şi Aurel Vlaicu, Apulum, 7, 1967, p. 73-84

M. Blăjan, Contribuţii la repertoriul aşezărilor rurale antice din Dacia romană, Apulum, 26, 1989, p. 283-334

Corina Borș, Protejarea patrimoniului arheologic din România. Despre situri si monumente arheologice din perspective evolutiei cadrului legislative in context european, Cluj-Napoca, 2014

Corina Borș, S. Dobrotă, Luciana Irimuș, C. Rișcuța, V. Rumega, C.-D. Țuțianu, Aurel Vlaicu - Obreza (Autostrada Al, lot 1, sit 2 - km 4+9005+150), CCA, 2013, p. 211-212, nr. 115

Olimpia Bratu, Depuneri de bronzuri între Dunărea Mijlocie şi Nistru în secolele XIII-VII a. Chr., București, 2009

H. Ciugudean, The Late Bronze Age in Transylvania (with primary focus on the central and Southem areas), în: L. Marta (ed./Hrsg.), Amurgul Mileniului II a. Chr. în Câmpia Tisei și Transilvania / Das Ende des 2. Jahrtausendes v. Chr. auf der Theiss-Ebene und Siebenbürgen. Simpozion / Symposium, Satu Mare 18-19 iulie 2008, Satu Mare. Studii si Comunicări. Seria Arheologie, XXVI/1, Satu Mare, 2010, p. 157-202

H. Ciugudean, Periodizarea culturii Gáva în Transilvania în lumina noilor cercetări, Apulum, 48, 2011, p. 69-102

H. Ciugudean, The Chronology of the Gáva Culture in Transylvania, în W. Blajer (ed.), Peregrinationes Archaeologicae in Asia et Europa Joanni Chochorowski dedicatae, Kraków, 2012, p. 229-243

P. Damian, I. Bocan, E. Dumitraşcu, D. Ene, S. Ene, M. Streinu, Autostrada Orăştie - Sibiu, Lot 1 (Orăștie - Sebeş), km 00+000-24+110, jud. Hunedoara, Alba, $C C A, 2012$, nr. 156, p. 280

Laura Dietrich, Die mittlere und späte Bronzezeit und die ältere Eisenzeit in Südostsiebenbürgen aufgrund der Siedlung von Rotbav, Teil 1-2, Universitätsforschungen zur Prähistorischen Archäologie, Band 248, Verlag Dr. Rudolf Habelt GmbH, Bonn, 2014

P. Drewett, Field Archaeology. An Introduction, $2^{\text {nd }}$ edition, Routledge, London, 2011

A.C. Florescu, Repertoriul culturii Noua-Coslogeni din România. Așezări şi necropole / Répertoire de la culture Noua - Coslogeni en Roumanie, CCDJ, IX, 1991

J-P. Jacob, Introduction, în G. Aubin, B. Mandy (texts réunis par), L'archéologie preventive : une demarche responsible. Actes des Rencontres autour de l'archéologie preventive 21-22 novembre 2012, Ministére de la Culture et de la Communication. Direction générale des patrimonies - sous-direction de l'archéologie, Paris, 2014, p. 189-190

A. László, Prima epocă a fierului, în vol. Istoria Românilor. Moștenirea timpurilor îndepărtate, vol. 1, Bucureşti, 2001, p. 294-326

Loi $n^{\circ} 2001-44$ du 17 janvier 2001 relative à l'archéologie préventive, version consolidée au 24 février 2004, disponibilă on-line http://www.legifrance.gouv.fr (accesat 15.10.2014) 
Giurgiu-Ardeu 1995-1996

Grant, Gorin, Fleming 2008

Greene 2002

Horedt 1944

Neumann, Sanford 2001

Orghidan 1969

Petrescu-Dâmboviţa 1977

Petrescu-Dâmboviţa 2001

Popa 1998

Popa 2011

Popa 2002

Popa, Totoianu 2010

PPG 16 (Marea Britanie)

Renfrew, Bahn 2008

Rişcuţa et alii 2011

Roskams 2001

Rusu 1963

Westcott, Brandon 2000
Adriana Giurgiu-Ardeu, Contribuţii privind stadiul cercetării Hallstattului timpuriu în spaţiul intracarpatic, Sargetia, 26, 1, 1995-1996, p. 189-226

J. Grant, S. Gorin, N. Fleming, The archaeology coursebook: An Introduction to study Skills, Topics and Methods, Routledge, 2008

K. Greene, Archaeology: an introduction, $4^{\text {th }}$ edition, Routledge, 2002

$\mathrm{K}$. Horedt, Die vorgeschichtliche und römische Abteilung des Baron Brukenthalischen Museum. Ein Überblick, Mitteilungen aus dem Baron Brukenthalischen Museum, N.F., Jg. 9/10, Hermannstadt/Sibiu, 1944

T.W. Neumann, R.M. Sanford, Practicing Archaeology. A Training Manual for Cultural Resources Archaeology, Walnut Creek, California, 2001 ( $6^{\text {th }}$ edition)

N. Orghidan, E. Nicolae (ed.), Văile transversale din România: Studiu geomorfologic, București, 1969

M. Petrescu-Dîmboviţa, Depozitele de bronzuri din România, București, 1977

M. Petrescu-Dâmboviţa, Mircea, Perioada târzie a epocii bronzului, în vol. Istoria Românilor. Moştenirea timpurilor îndepărtate, vol. 1, Bucureşti, 2001, p. 272-287

C. I. Popa, Noi descoperiri aparţinând bronzului timpuriu în bazinul mijlociu al Mureşului şi câteva consideraţii privind etapa finală a acestei perioade în Transilvania, Apulum, 35, 1998, p. 47-85

C. I. Popa, Valea Cugirului din preistorie până in zorii epocii moderne, Monumenta archaeologica et historica, Cluj-Napoca, 2011

D. Popa, Villae, vici, pagi. Așezările rurale din Dacia romană intracarpatică, Bibliotheca Septemcastrensis, II, Sibiu, 2002

C. I. Popa, R. Totoianu, Noi opinii privitoare la evoluția cultural a bronzului târziu în zona central şi sud-vest transilvăneană, în vol. Aspecte ale epocii bronzului în Transilvania (între vechile și noile cercetări), Bibliotheca Musei Sabiensis, I, Sebeș, 2010, p. 171-291

***, Planning Policy Guidance 16: Archaeology and planning, 1990, disponibilă on-line

http://www.planningportal.gov.uk/planning/planningpolicyandlegislation/ previousenglishpolicy/ppgpps/ppg16 (accesat 15.10.2014)

C. Renfrew, P. Bahn, Archaeology: Theories, Methods and Practice, $5^{\text {th }}$ edition, Thames \& Hudson, Londra, 2008

C. N. Rișcuța, A.T. Marc, loana Lucia Barbu, I.A. Bărbat, Cercetări arheologice în judeţul Hunedoara pe traseul autostrăzii (tronsoanele Lugoj - Deva şi Orăştie - Sibiu), Sargetia, S.N., 2, 2011, p. 53-134

S. Roskams, Excavation, Cambridge Manuals in Archaeology, Cambridge University Press, 2001

M. Rusu, Die Verbreitung die Bronzehorte in Transilvannien vom Ende Bronzezeit in die mitllere Hallstattzeit, Dacia N.S., 7, 1963, p. 177-210

Konnie L. Westcott, J. Brandon (eds.), Practical Applications of GIS for Archaeologists. A Predictive Modeling Toolkit, Taylor Francis, London 2000

LIST OF ILLUSTRATION

PI. I Location of the site on ortophotomap (2005)

PI. II Location of the site on historic maps

PI. II General views at the beginning and the completion of the preventive archaeological excavations

Pl. IV General views during the preventive archaeological excavations

PI. V Layout of the excavation units

PI. VI Layout of the archaeological complexes

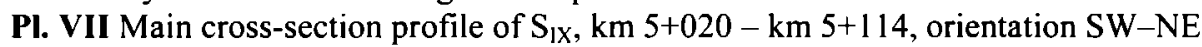

PI. VIII Detail images of certain parts of cross-sections profiles

PI. IX Complex 012: 1. Ground plan and profile; 2-4. Images durings the identification, cross-sectioning and completion 
PI. X Complex 017: 1. Ground plan and profile; 2-4. Images durings the identification, cross-sectioning and completion

PI. XI Complex 019, 1. Ground plan and profile; $2-4$. Various excavation stages

PI. XII Complex 041, 1. Ground plan and profile; $2-4$. Images durings the identification, cross-sectioning and completion

PI. XIII Complex 045: 1. Ground plan and profile; 2-4. Various excavation stages

PI. XIV Complex 048: 1. Ground plan and profile; 2-7. Various excavation stages

PI. XV Complexes 051-052 (from left to right), ground plans and profiles

PI. XVI Complexes 051-052, Images durings the identification, cross-sectioning and completion: 1-3. Complex 051; 4-5. Complex 052

PI. XVII Complexes 055-056 (from left to right), ground plans and profiles

Pl. XVIII Complexes 055-056, Images durings the identification, cross-sectioning and completion: 1 . Complex 055, 2. Complex 056

PI. XIX Complex 058: 1. Ground plan and profile; 2-4. Images durings the identification, cross-sectioning and completion

PI. XX Complex 064: 1. Ground plan and profile; 2-4. Images durings the identification, cross-sectioning and completion

PI. XXI Complex 069: 1. Ground plan and profile; 2-4. Images durings the identification, cross-sectioning and completion

PI. XXII Complexes 080-081: 1-3. Images durings the identification, cross-sectioning and completion complex $081 ; 4$. ground plans and profiles (from left to right) Complexes 080 and $081 ; 5-7$. Images durings the identification, cross-sectioning and completion Complex 080

PI. XXIII Complex 088: 1. Ground plan and profile; 2-4. Images durings the identification, cross-sectioning and completion

PI. XXIV Complex 110: 1. Ground plan and profile; 2-3. Images durings the identification, cross-sectioning and completion

PI. XXV Distribution of special archaeological material

PI. XXVI Noua type pottery and channelled pottery

Pl. XXVII Typical pottery fragments of complexes' inventory (selective): 1. Complex 013; 2-3. Complex 012; 4. Complex 015; 5. Complex 016; 6. Complex 017

PI. XXVIII Typical pottery fragments of complexes' inventory (selective): 1. Complex 043; 2. Complex 036; 3. Complex 030; 4. Complex 033; 5. Complex 041; 6. Complex 018

PI. XXIX Typical pottery fragments of complexes' inventory (selective): 1. Complex 047; 2. Complex 052;

3. Complex 048; 4. Complex 067; 5. Complex 055; 6. Complex 051

PI. XXX Typical pottery fragments of complexes' inventory (selective): 1. Complex 097; 2. Complex 081; 3. Complex 069; 4. Complex 120; 5. Complex 079; 6. Archaeological layer

PI. XXXI A. Noua type pottery fragments (selective): 1-2. Complex 120;3. Complex 015; 4. Complex 012; 5. Complex 048; B. Channelled pottery fragments (selective): 1-2. Complex 012; 3. Complex 001; 4-7. Complex 097; 8-11. Complex 051; 12. Complex 041; 13. Complex 013

Pl. XXXII Restored ceramic vessels (selective): 1-2. Complex 081; 2. Complex 111; 3. Complex 033; 4. Complex 053; 5. Archaeological layer; 6. Complex 100; 7. Archaeological layer

PI. XXXIII Restored ceramic vessels (selective): 1. Northern main cross-section profile of $\mathrm{S}_{\mathrm{v}}$; 2. Complex 111; 3. Complex 081; 4-7. Complex 056

PI. XXXIV Clay objects: 1. weights; 2. unperforated disk; 3. miniature chariot wheels; 4. spindle-whorls / perforated disk

PI. XXXV 1. Lithic material (tools and cast moulds); 2. Objects of processed bones

Pl. XXXVI 1. Bronze objects (castings scraps, pins, dagger, small knife); 2. Iron knife

Pl. XXXVII Drawings of restored potter vessels (selective)

PI. XXXVIII Drawings of restored potter vessels (selective)

PI. XXXIX Drawings of restored potter vessels (selective)

PI. XL Drawings of restored potter vessels (selective)

CORINA Borș, LuCiana RUMEGa-IRIMUS, Vlad RUMEGa-IRIMUȘ, SEbastian Dobrotã Muzeul Naţional de Istorie a României corina.bors73@gmail.com; luciana_dr@yahoo.com; vladrumega@gmail.com CÁTĂLIN RIŞCUȚA, COSTIN ȚUȚUIANU Muzeul Civilizației Dacice și Romane 

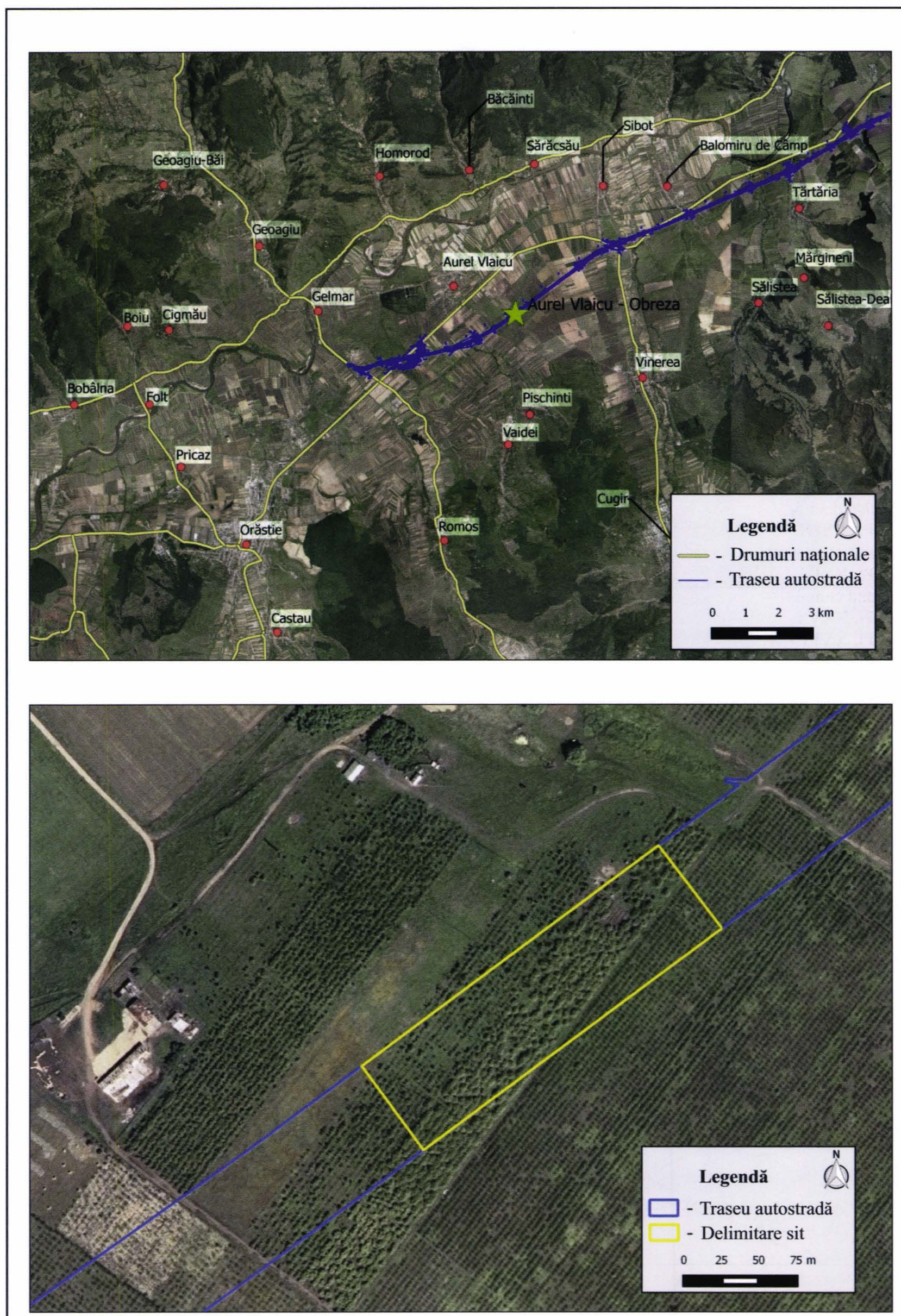

Încadrarea zonei cercetate pe ortofotoplan (2005) 


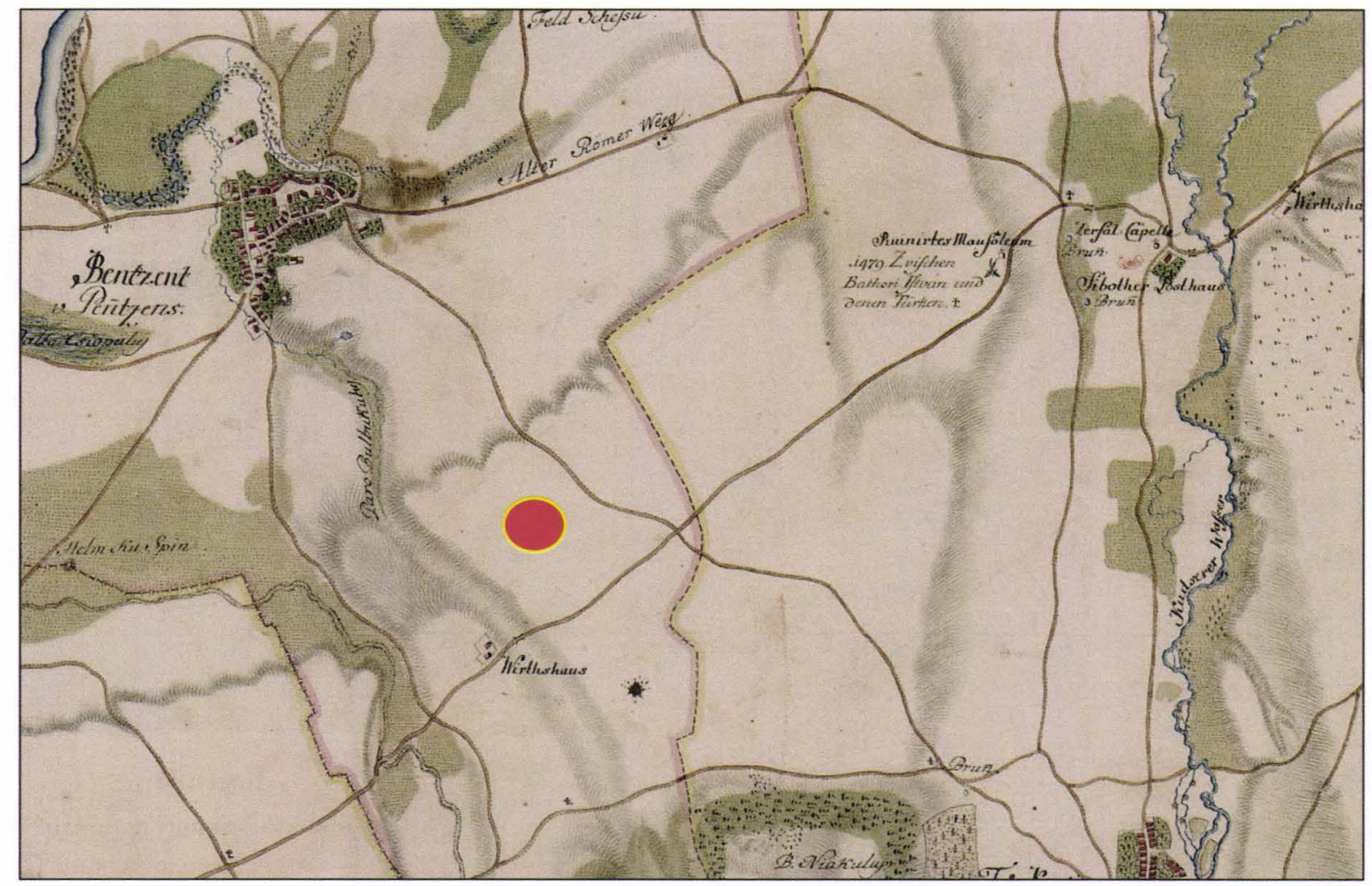

Harta iosefină a Transilvaniei (1769-1773)

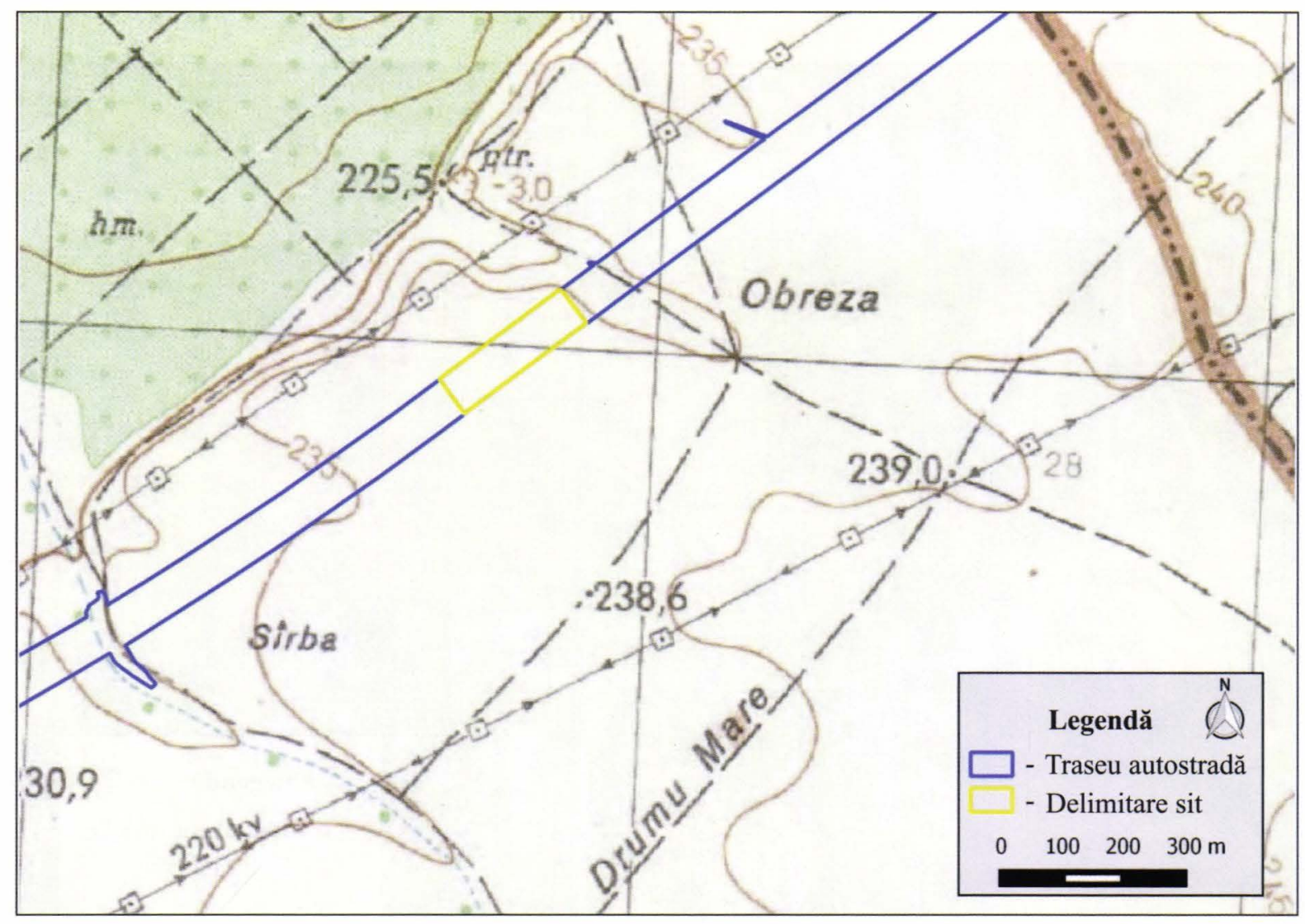

Harta topografică a României 1:25.000 (1977-1985)

Localizarea sitului pe hărţi istorice 

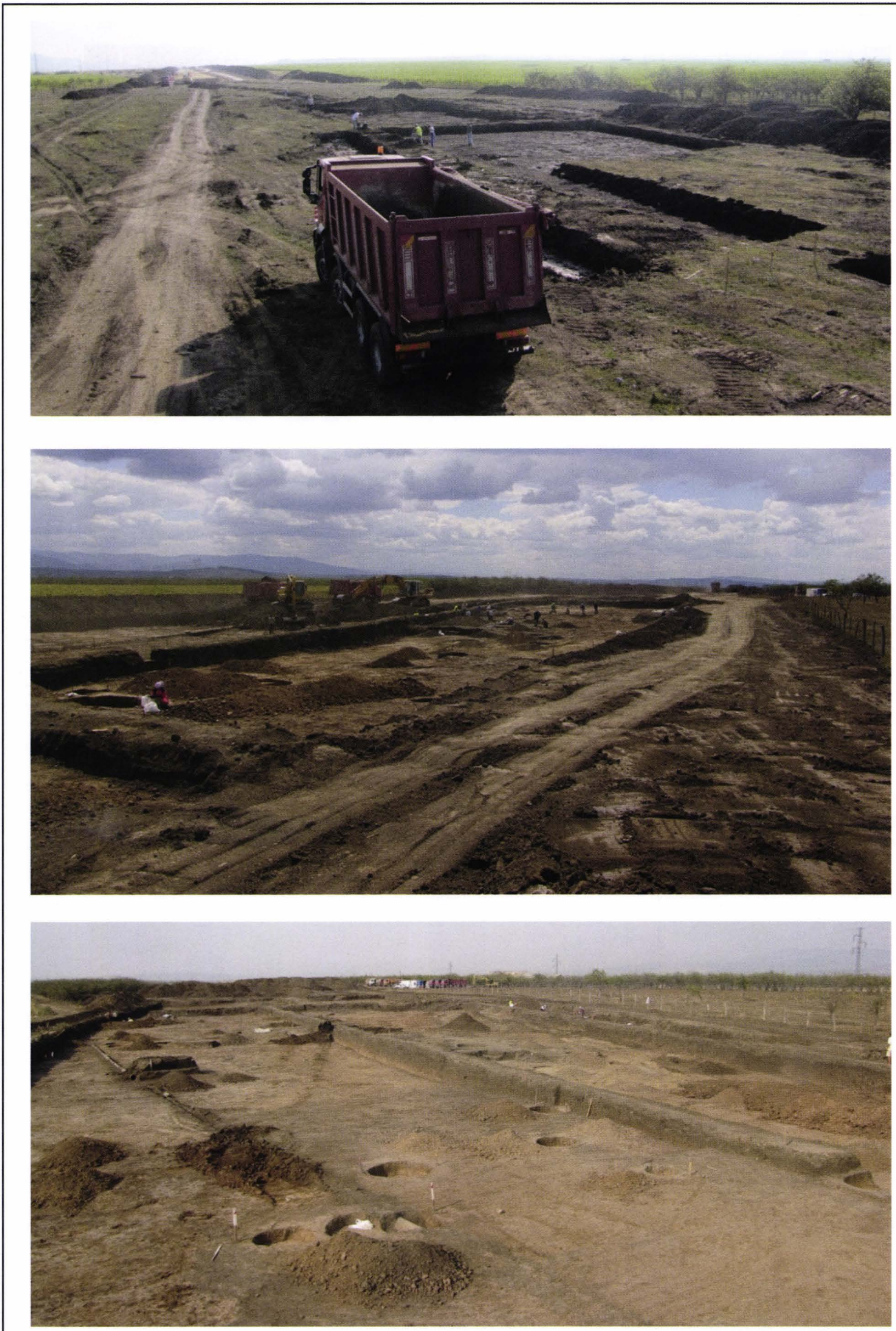

Imagini de ansamblu de la începutul şi finalizarea săpăturii 

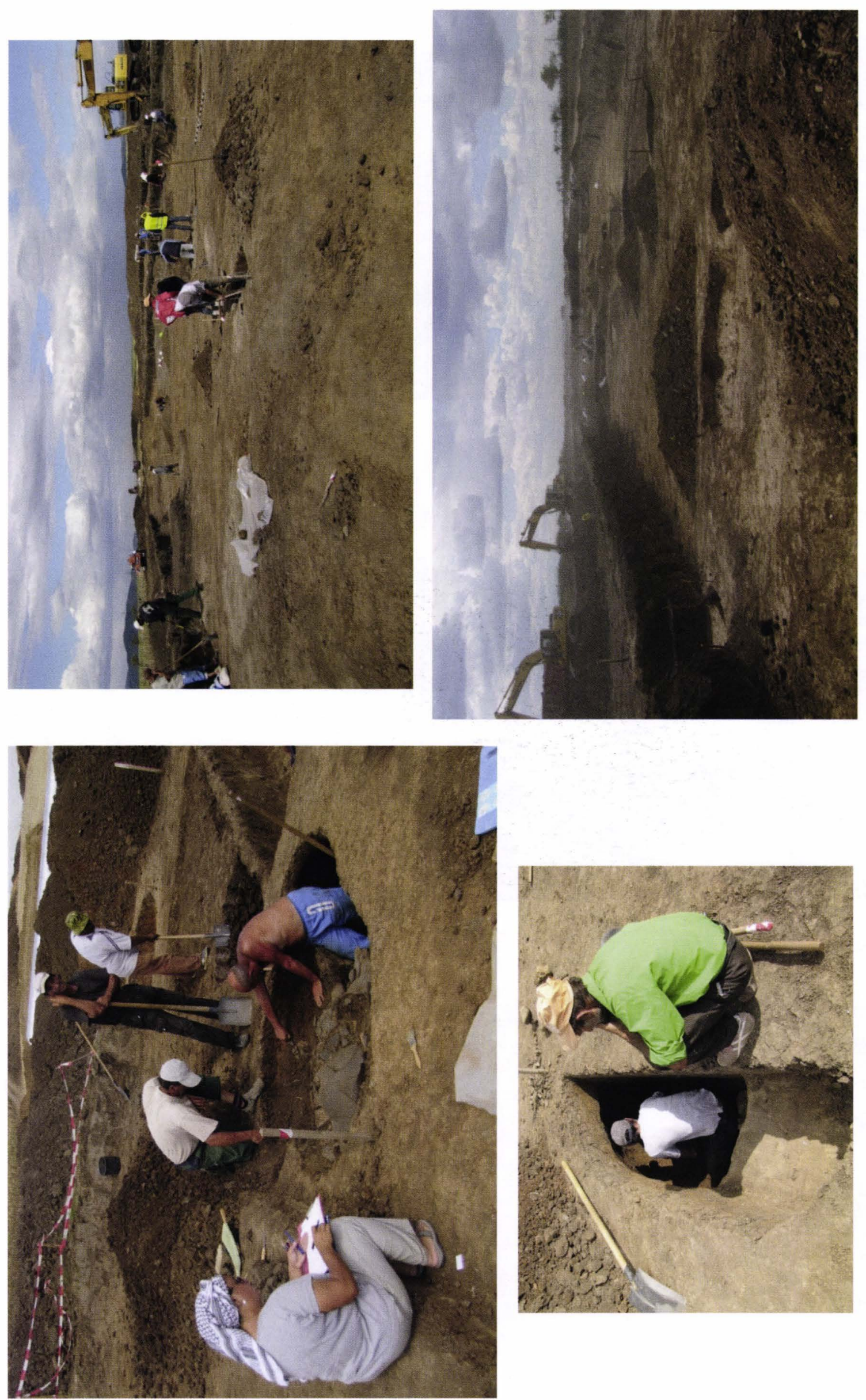

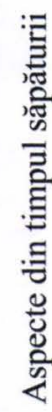

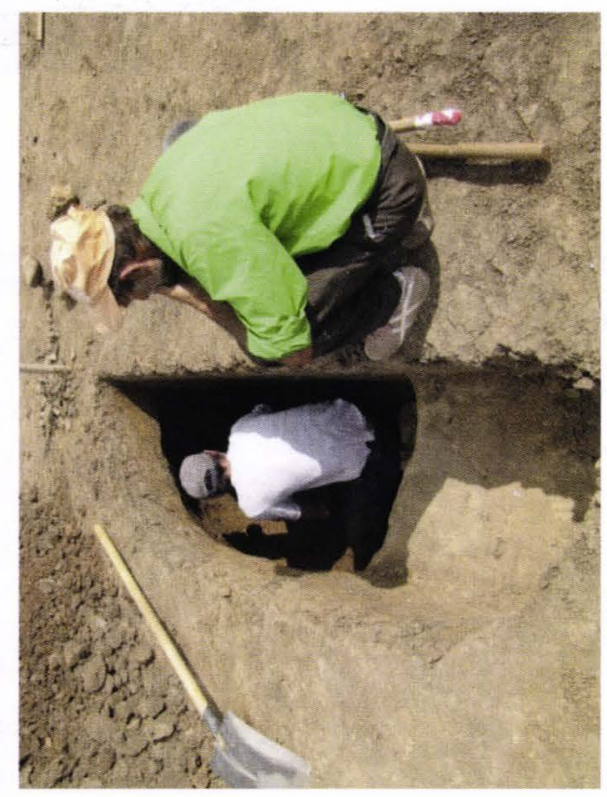




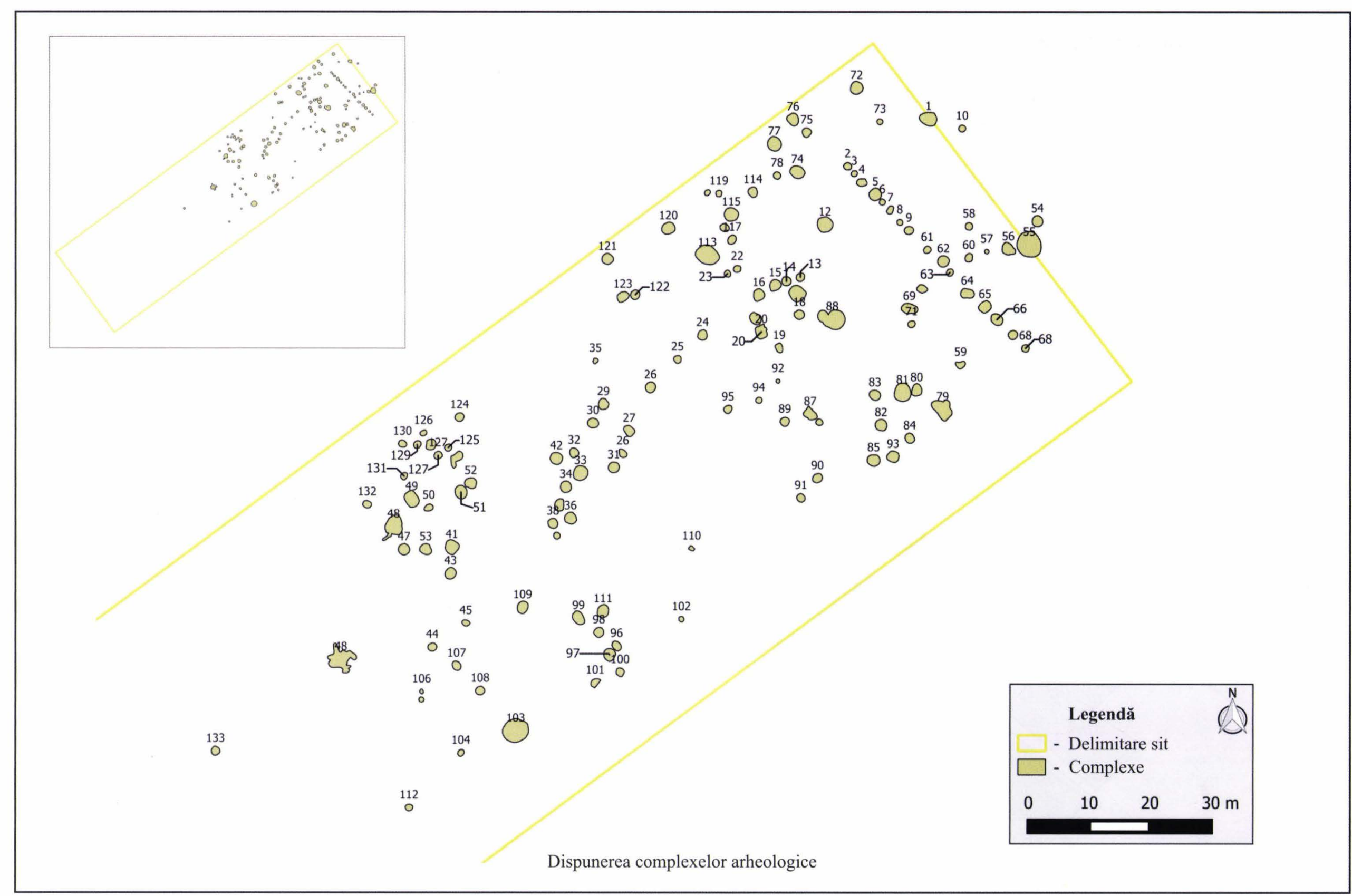


$\mathrm{km} 5+020$
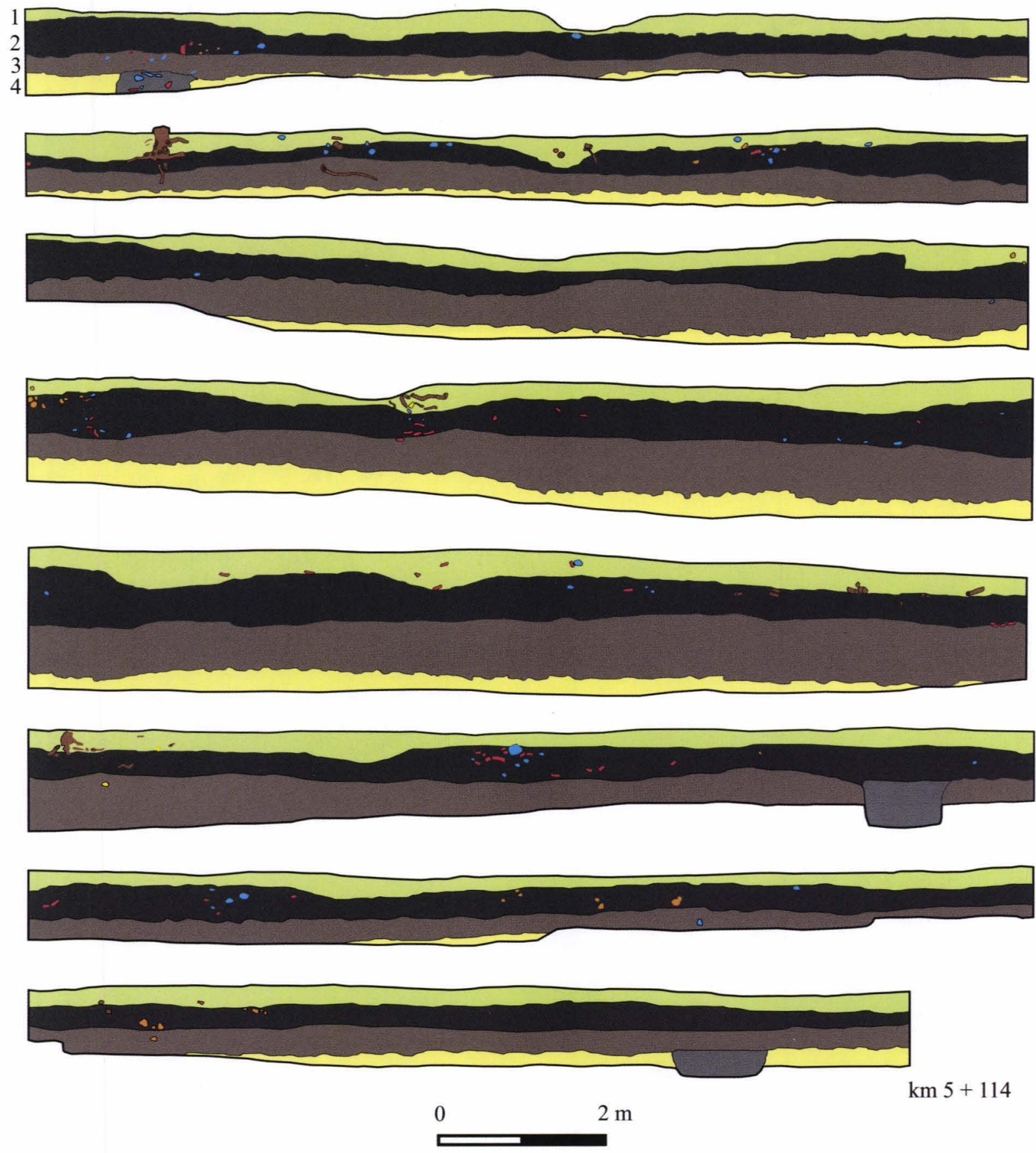

$1 \square$ Vegetal

2 Strat negru, sfărâmicios cu pigment de chirpici şi material arheologic, puternic afectat de lucrări agricole şi livadă

3 Strat brun-cenuşiu amestecat cu chirpici, cărbune, cenuşă dar cu material arheologic mai puţin

$4 \square$ Galben steril

Umplutură complexe

Ceramică

Rădăcini pomi

Chirpici

Os de animal

Piatră

Profil magistral $\mathrm{S}_{\mathrm{IX}}, \mathrm{km} \mathrm{5+020-km} \mathrm{5+114,} \mathrm{orientare} \mathrm{SV-NE}$ 


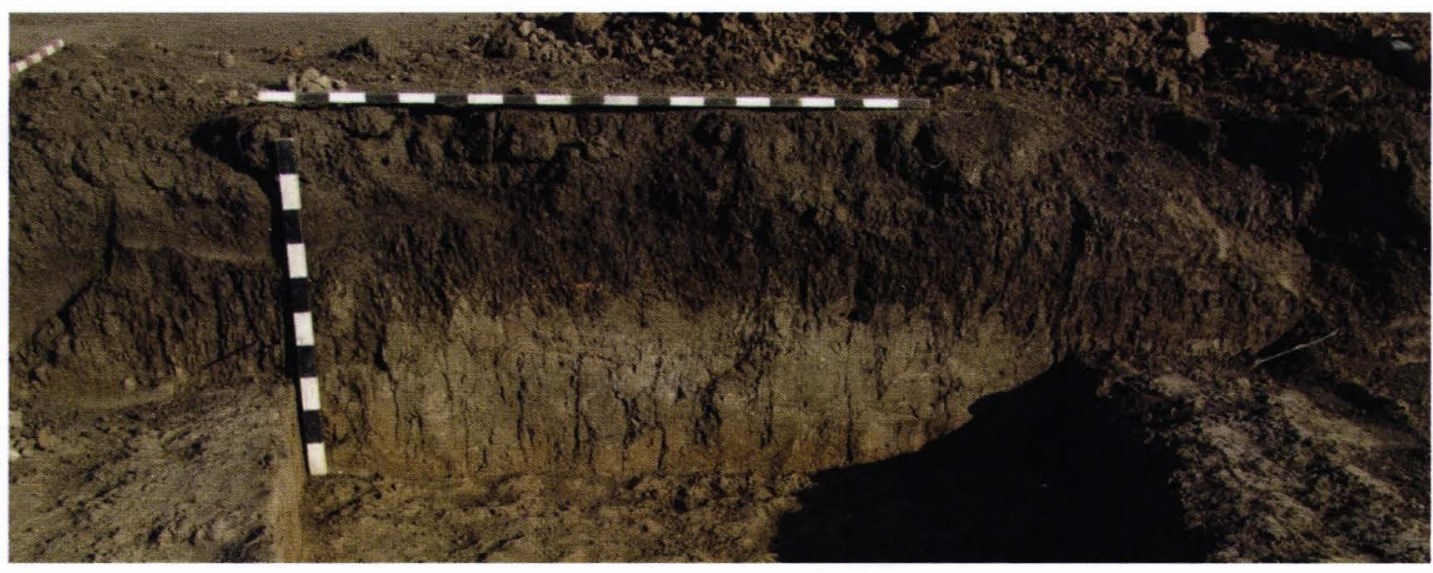

1.

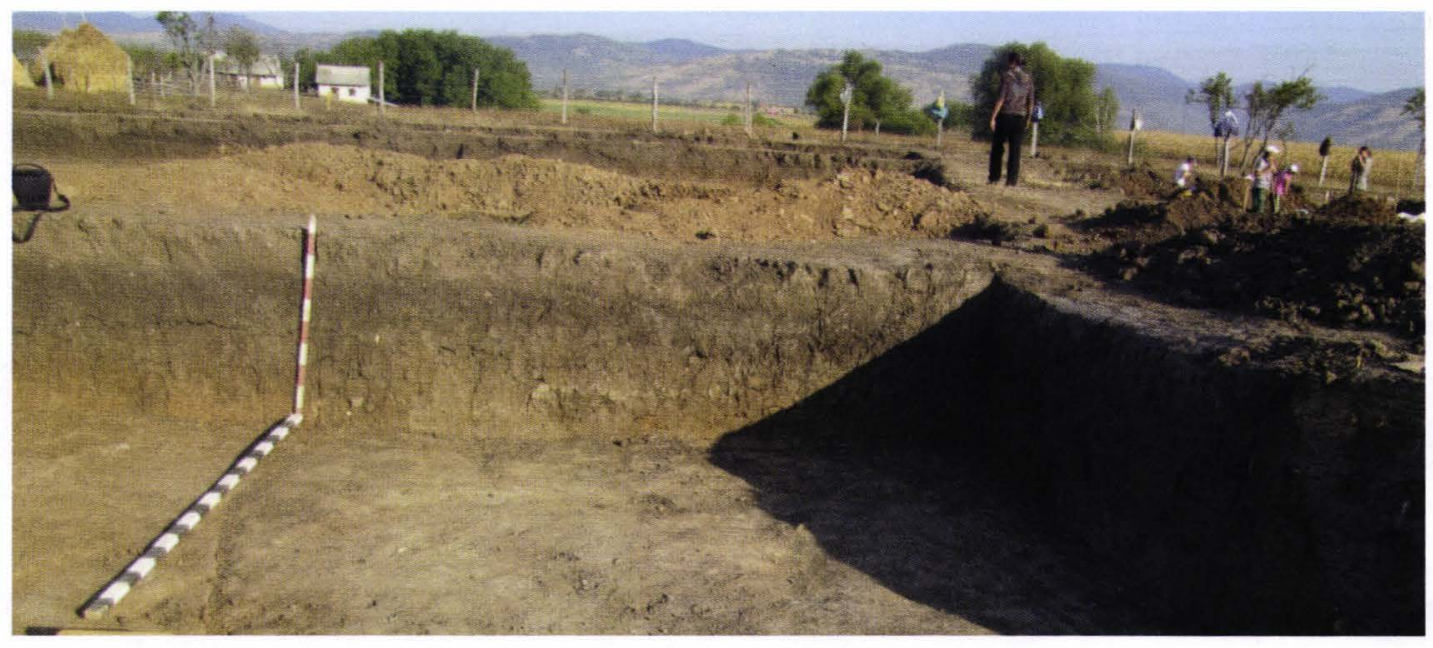

2.

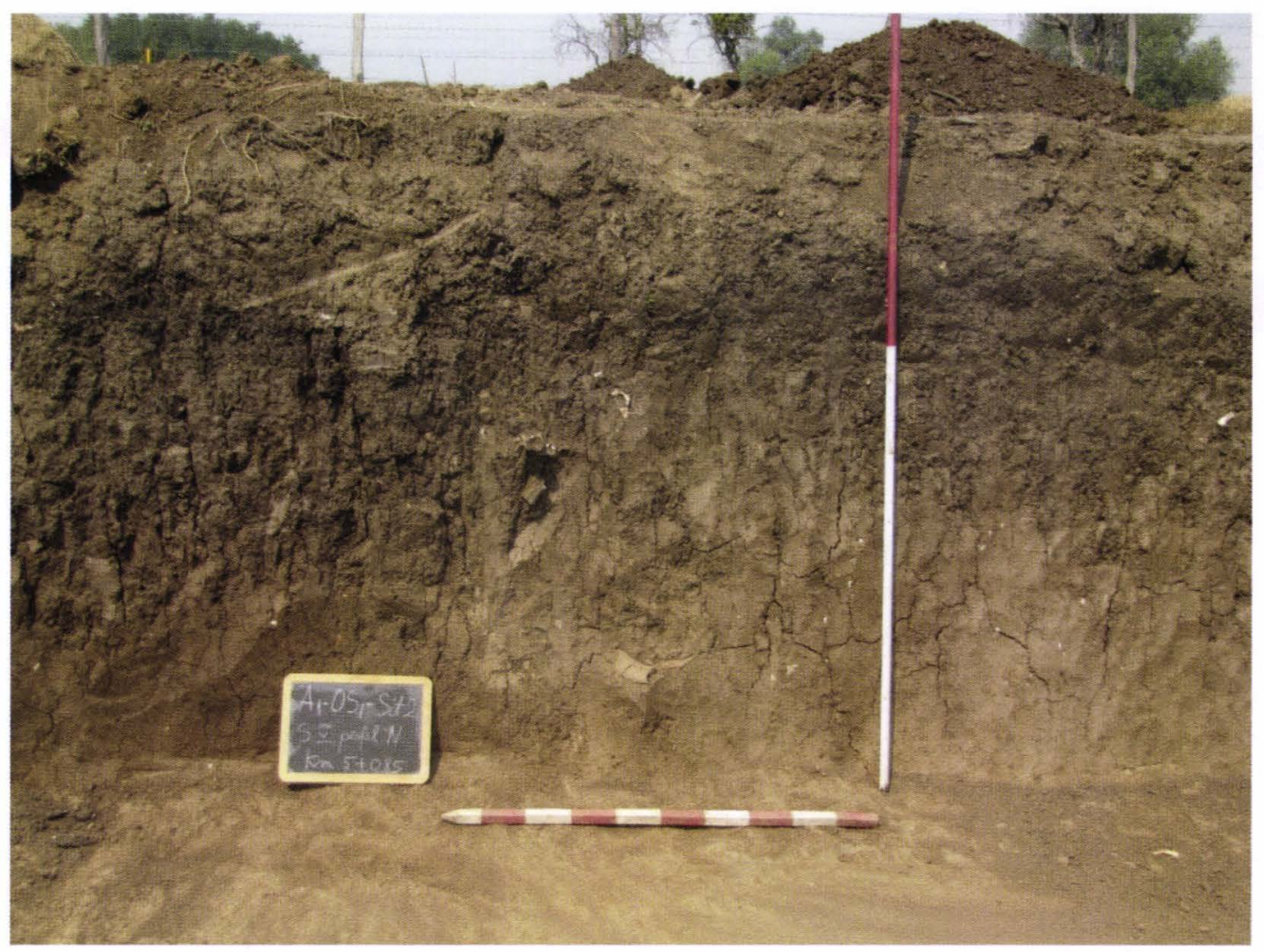

3.

Imagini de detaliu al unor porțiuni de profile magistrale 


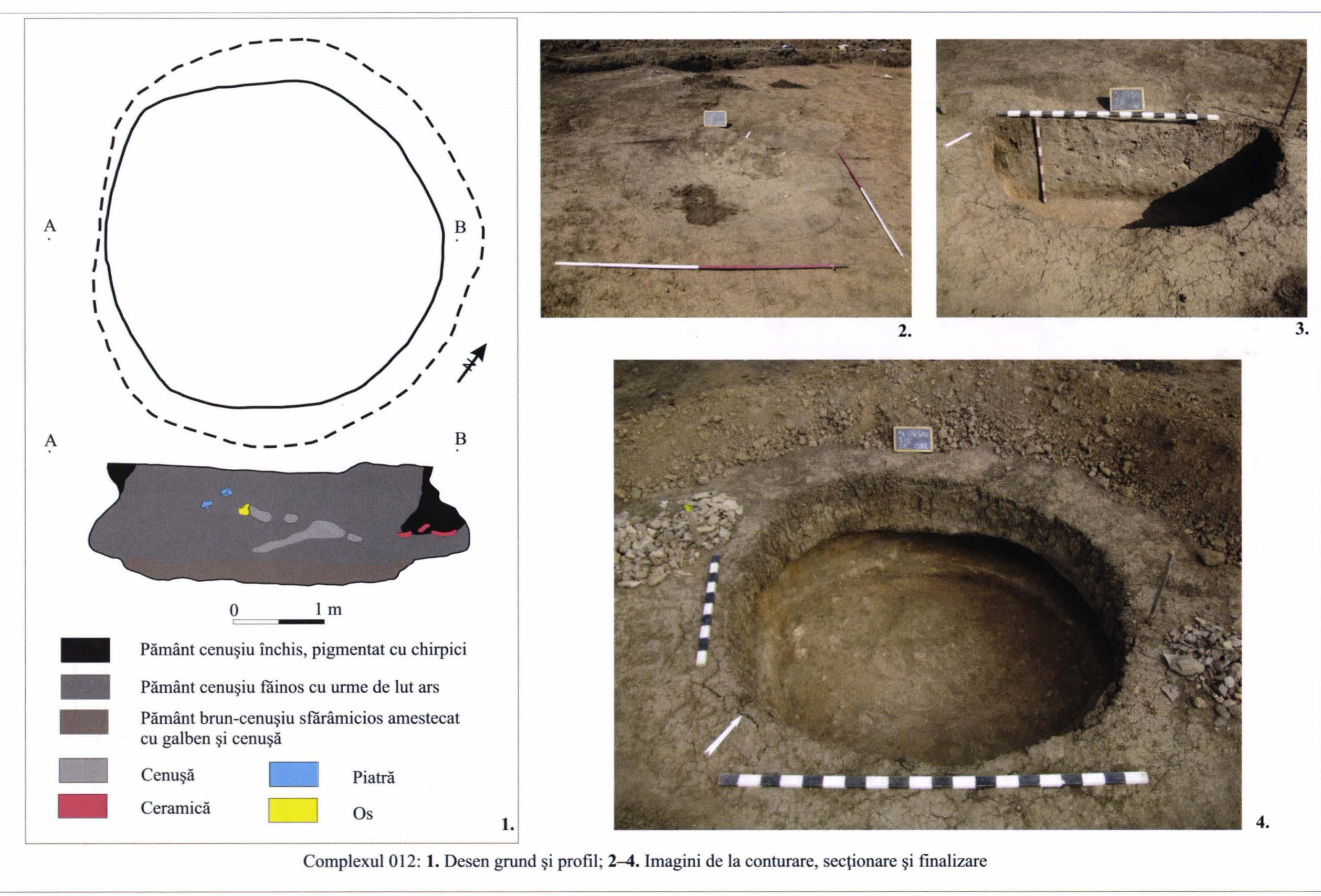




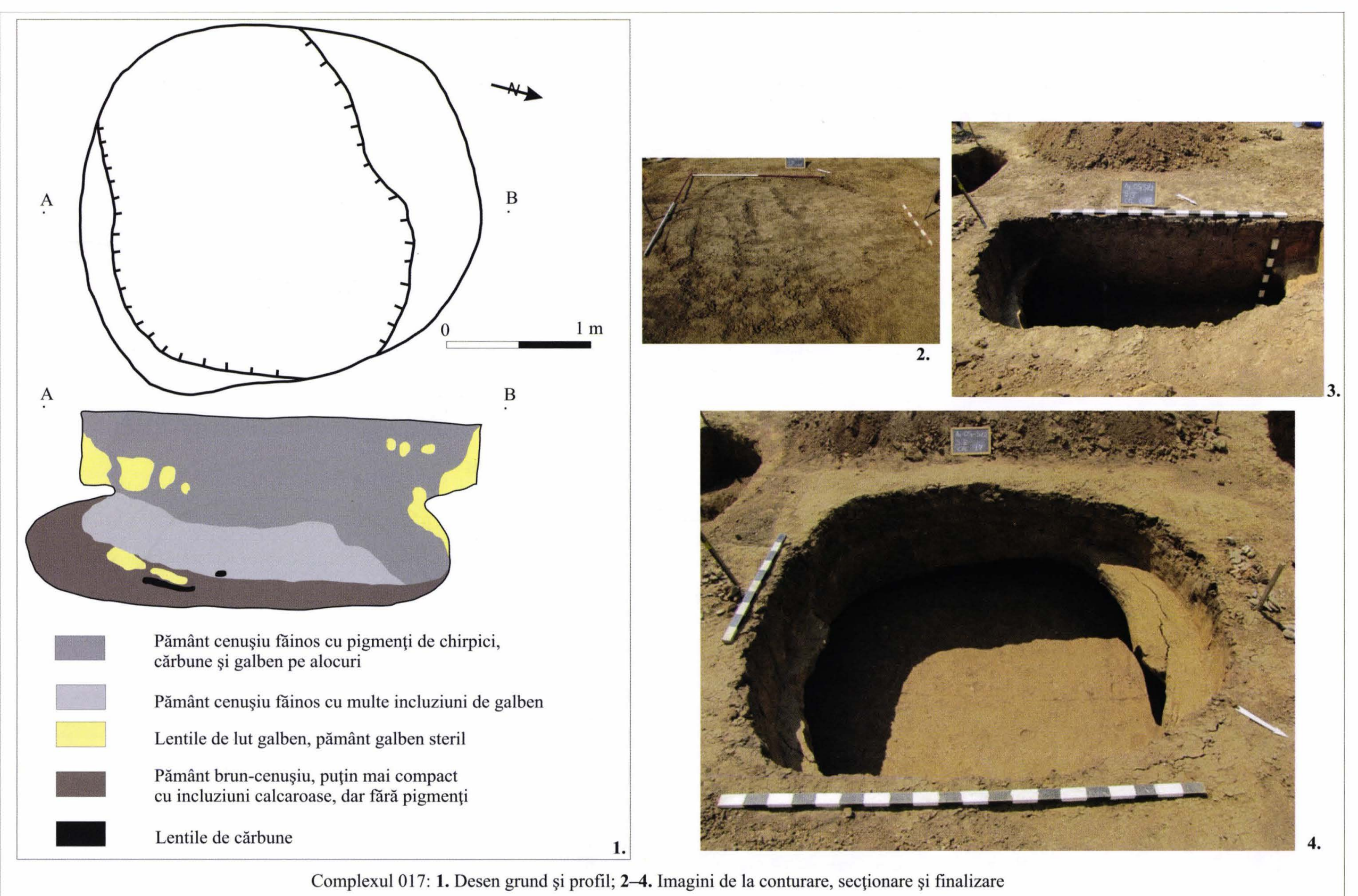

Pl. X 

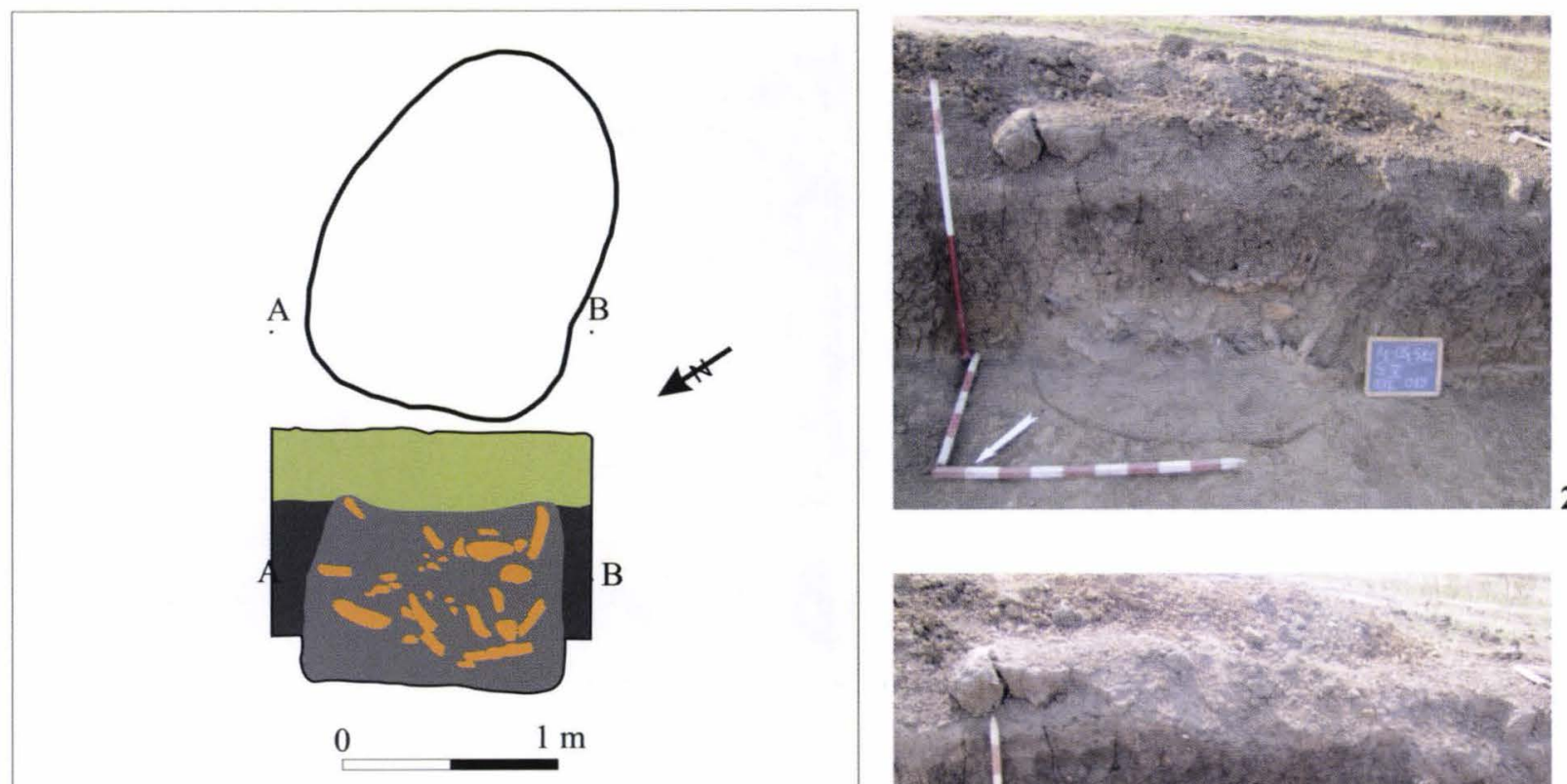

2.

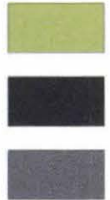

Vegetal

Pământ negru compact cu pigment de chirpici

Pământ negru-cenuşos cu foarte multe urme de cărbune şi chirpici

ChipicI şi lipitură de vatră

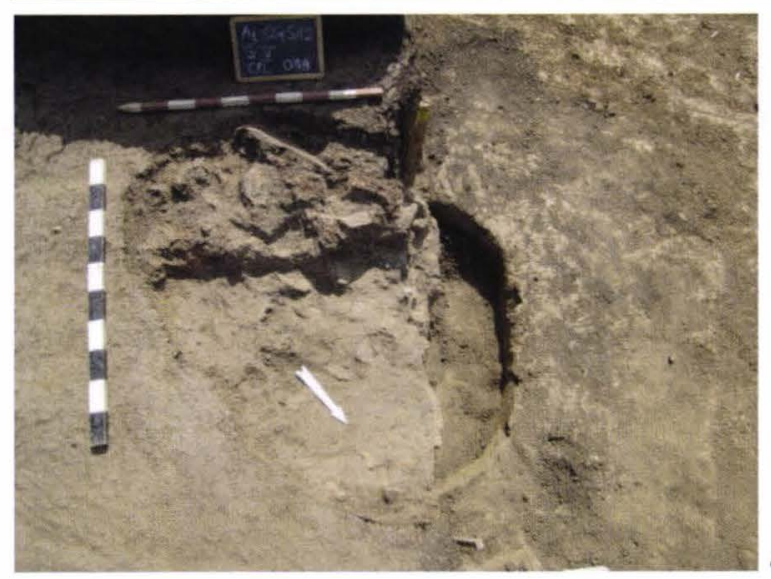

1.

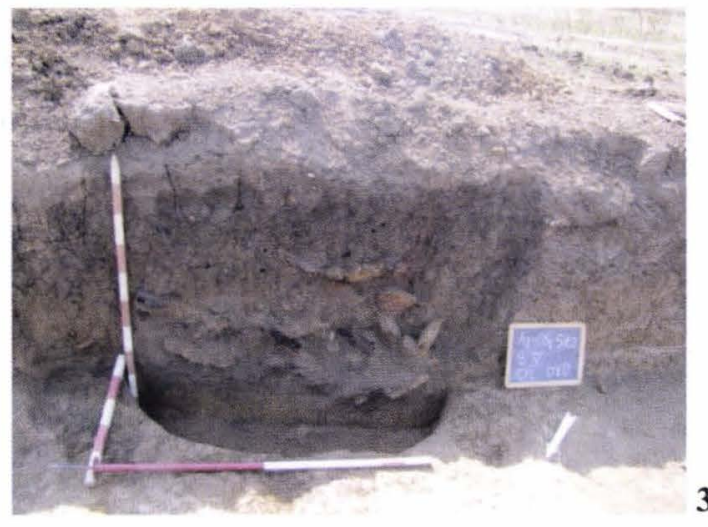

4.
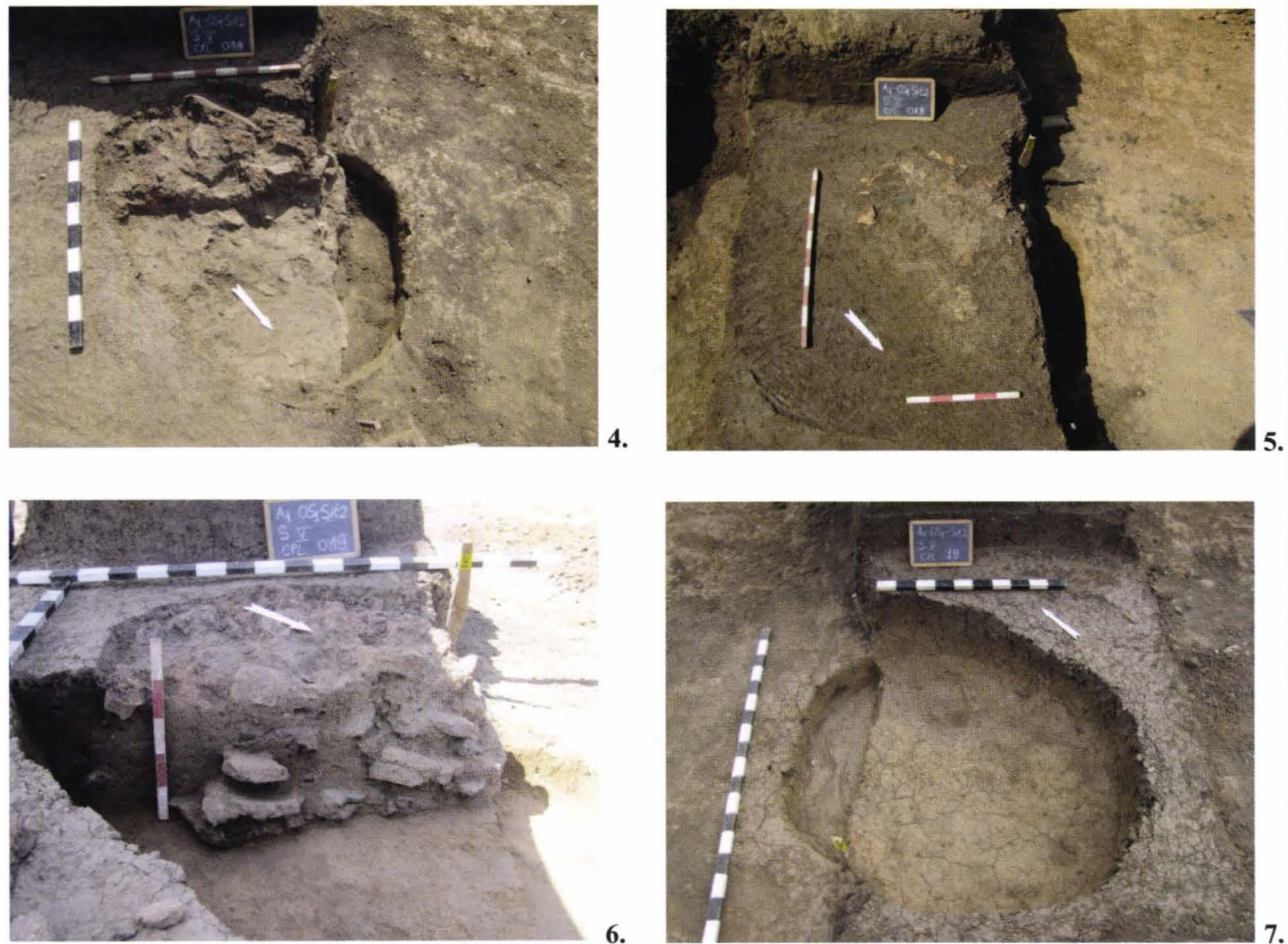

Complexul 019: 1. Desen grund şi profil; 2-7. Diverse etape din timpul cercetării complexului 

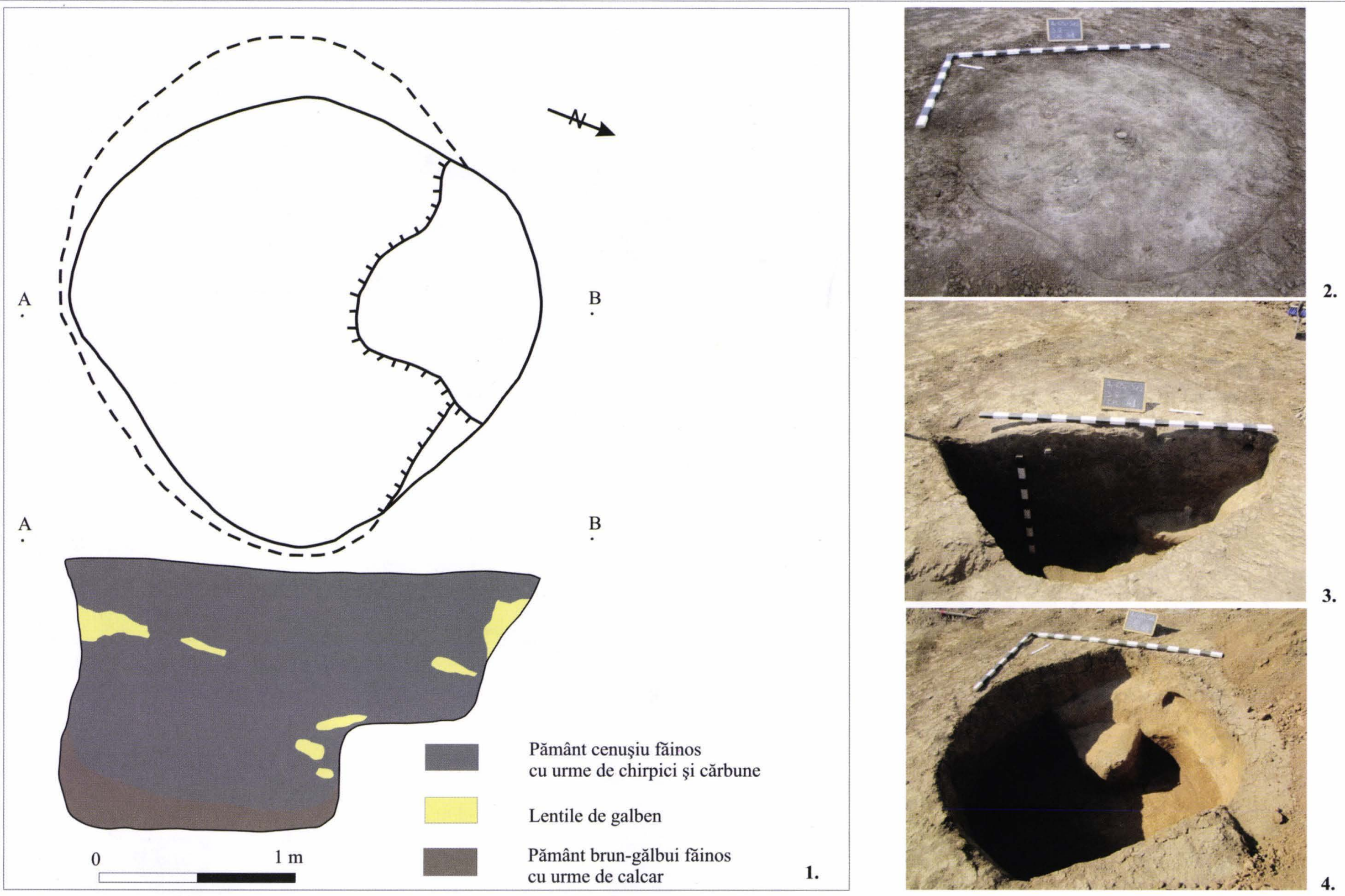

Complexul 041: 1. Desen grund și profil; 2-4. Imagini de la conturare, secționare și finalizare 

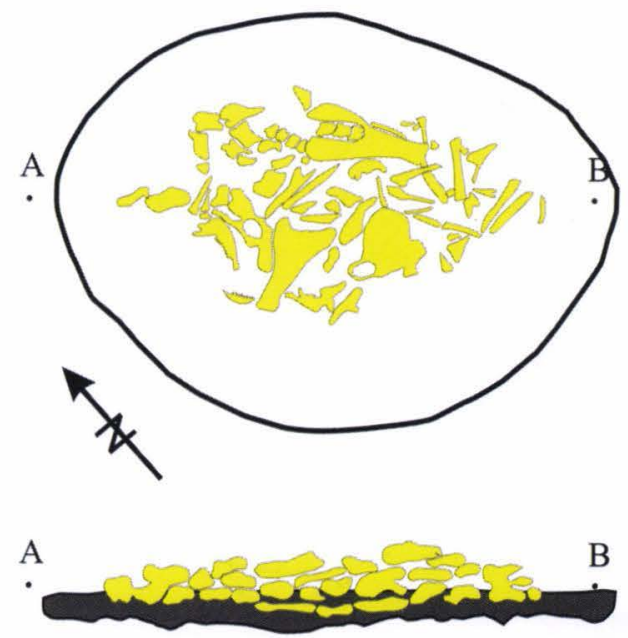

0

$1 \mathrm{~m}$

Pământ negru compact, foarte bine tasat

Oase de animal

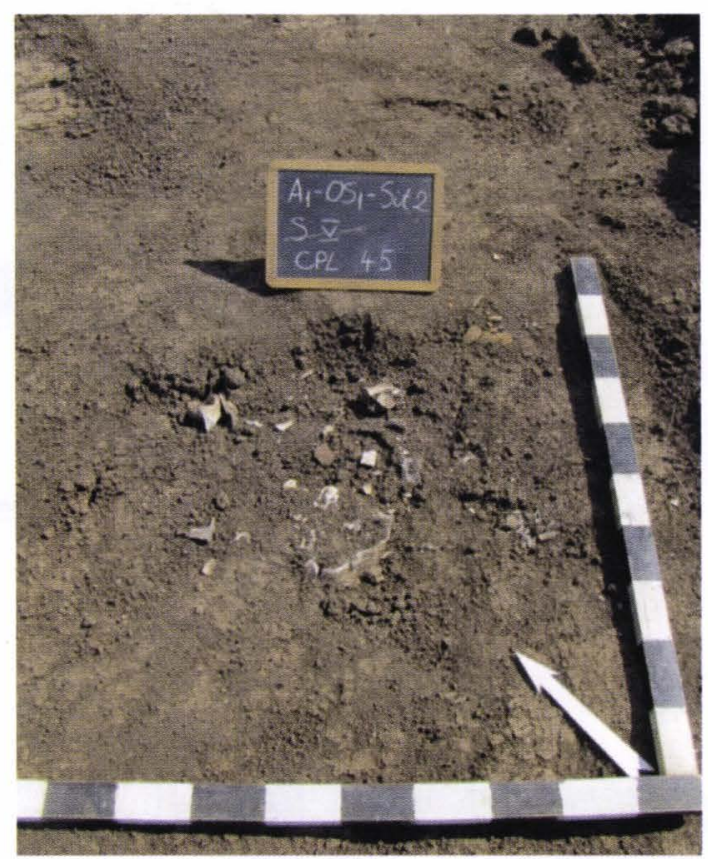

1.

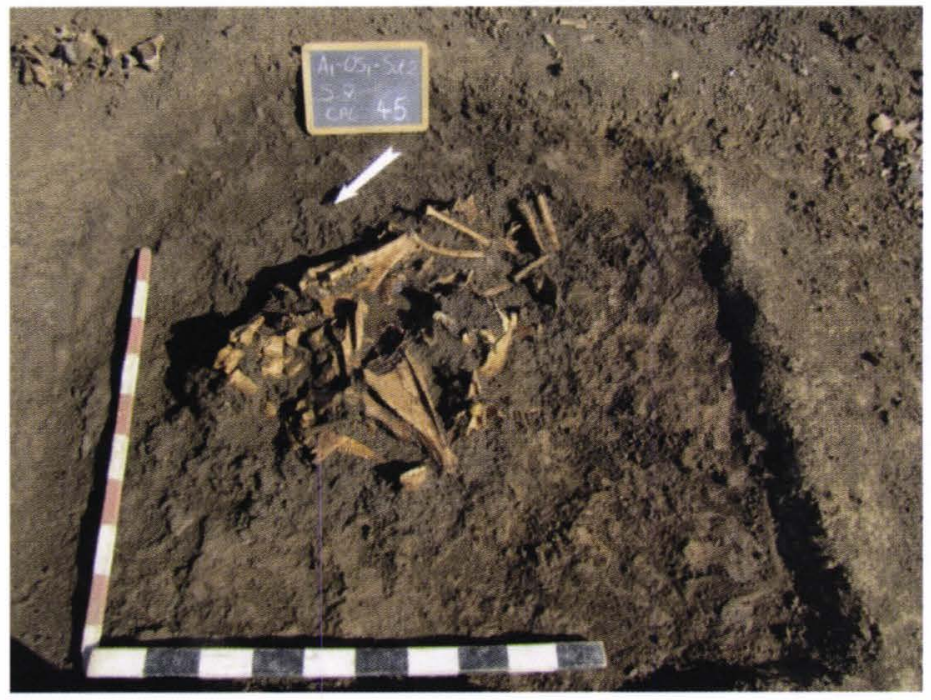

3.
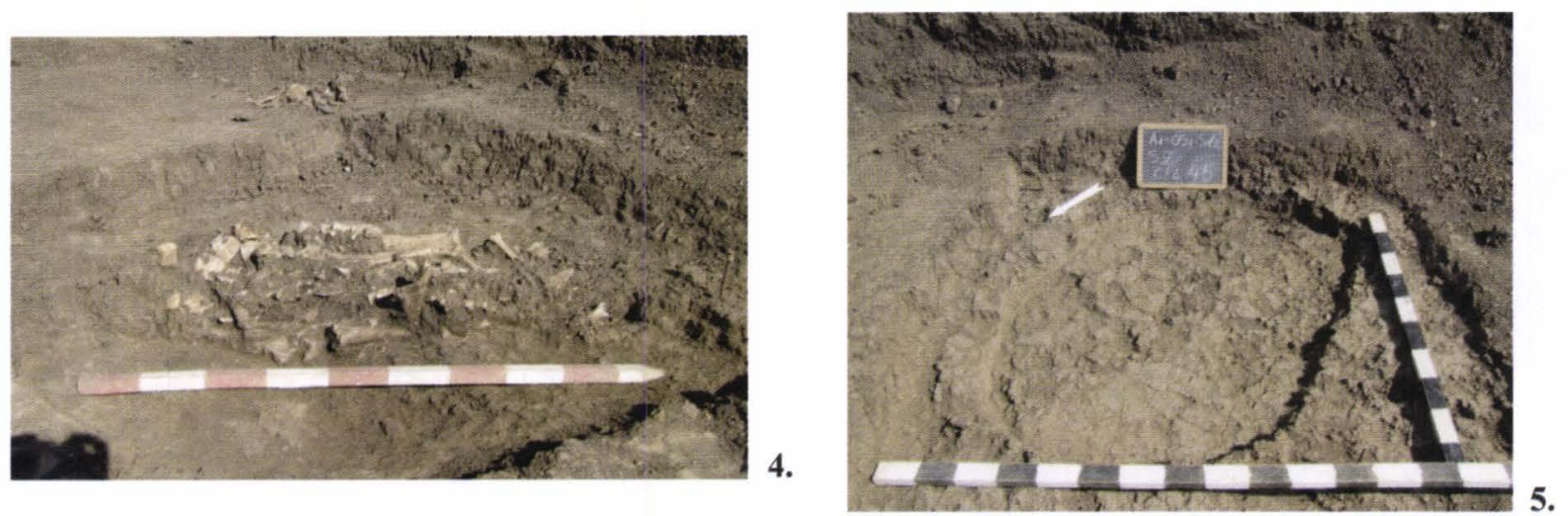

Complexul 045: 1. Desen grund și profil; 2-4. Diverse etape din timpul cercetării complexului 

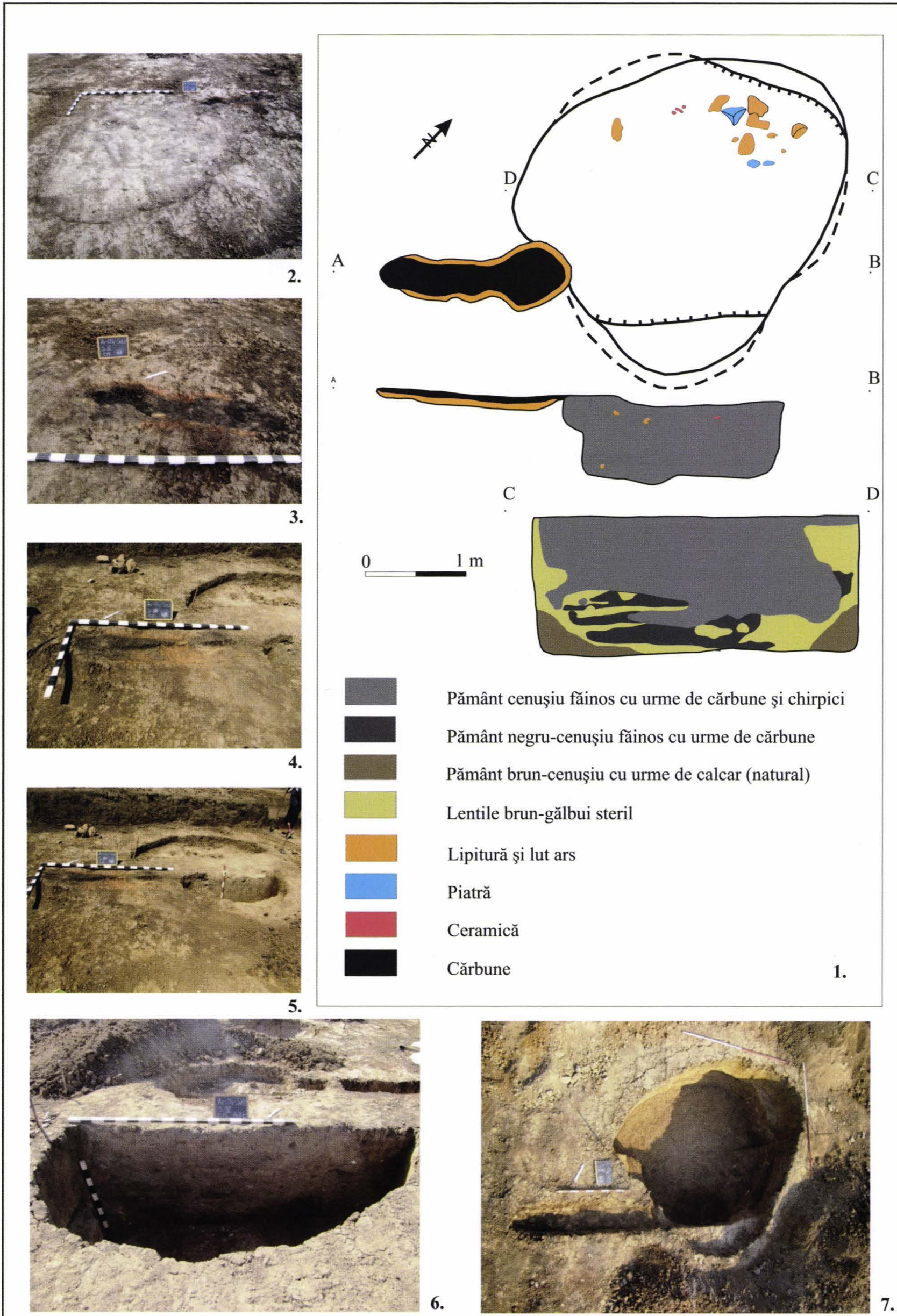

6.

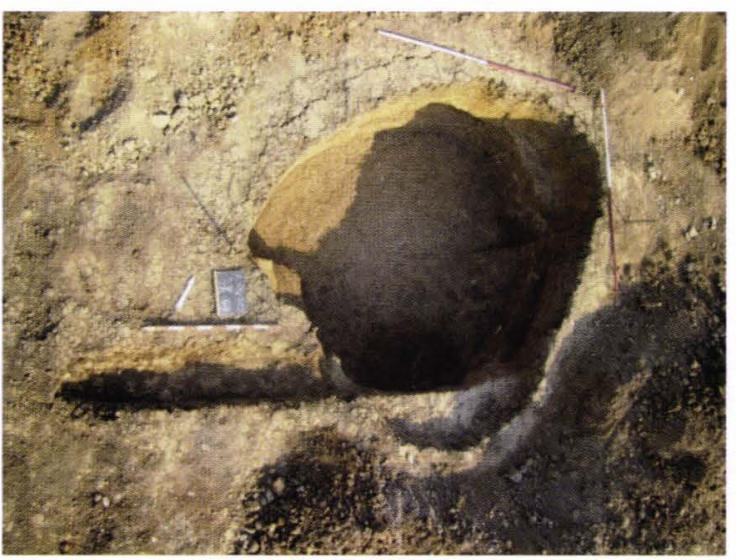

Complexul 048: 1. Desen grund şi profil; 2-7. Diverse etape din timpul cercetării complexului 


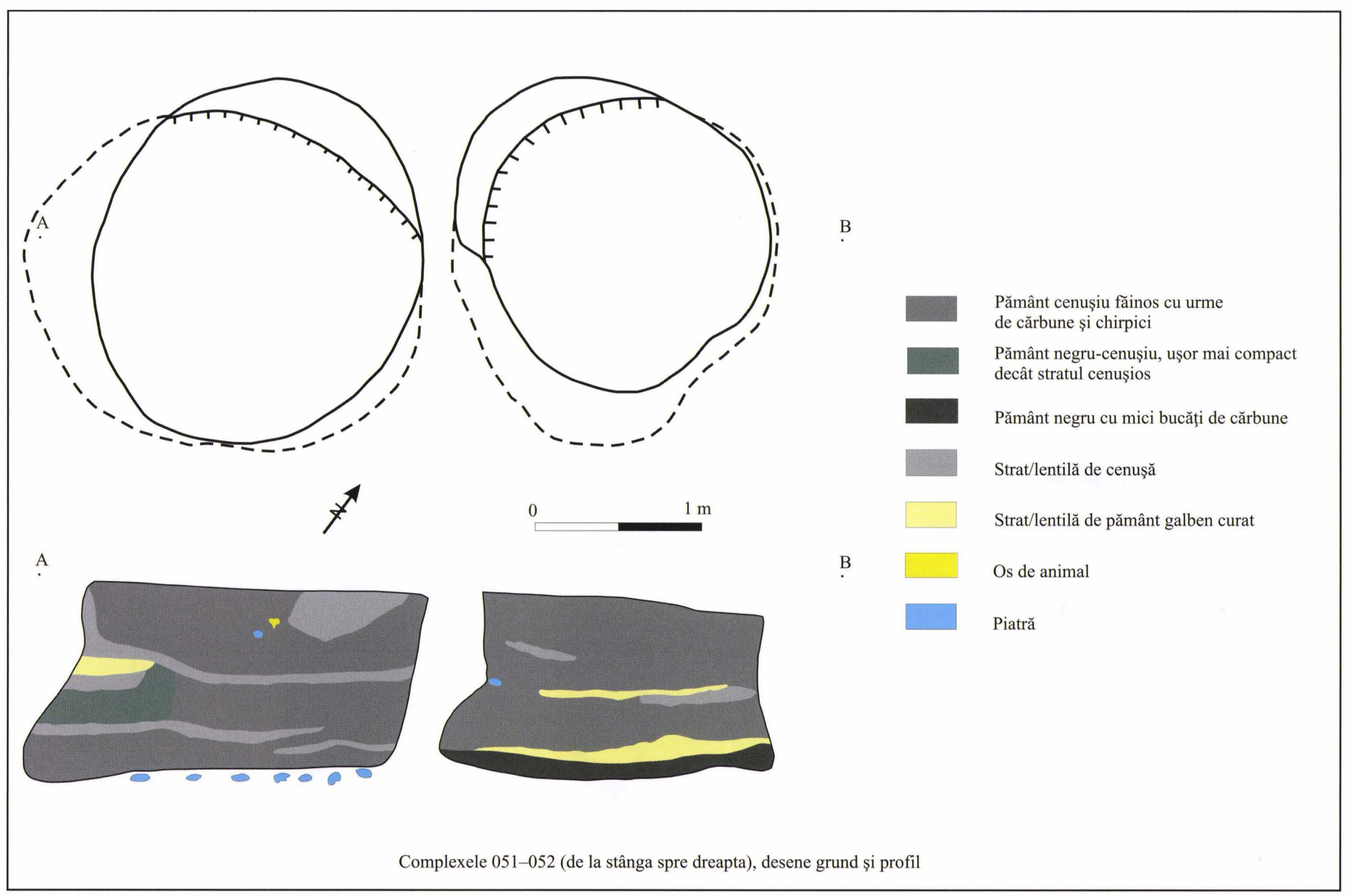



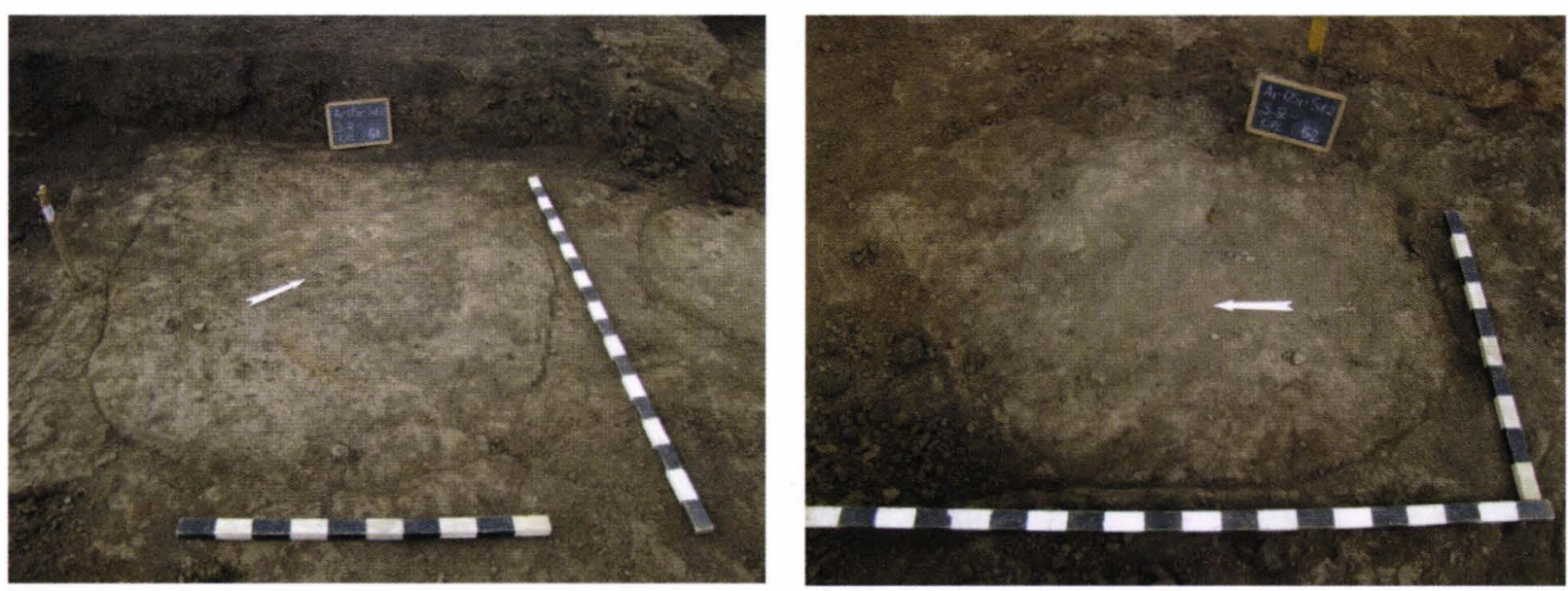

1.
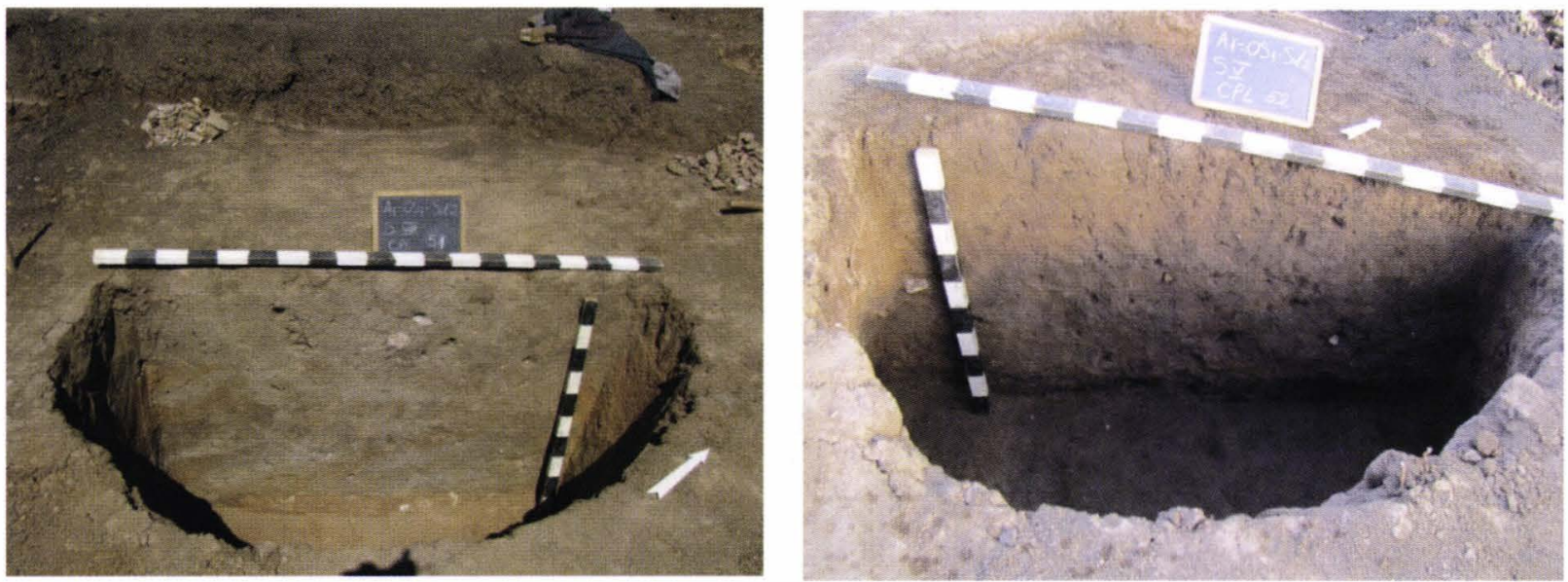

2.
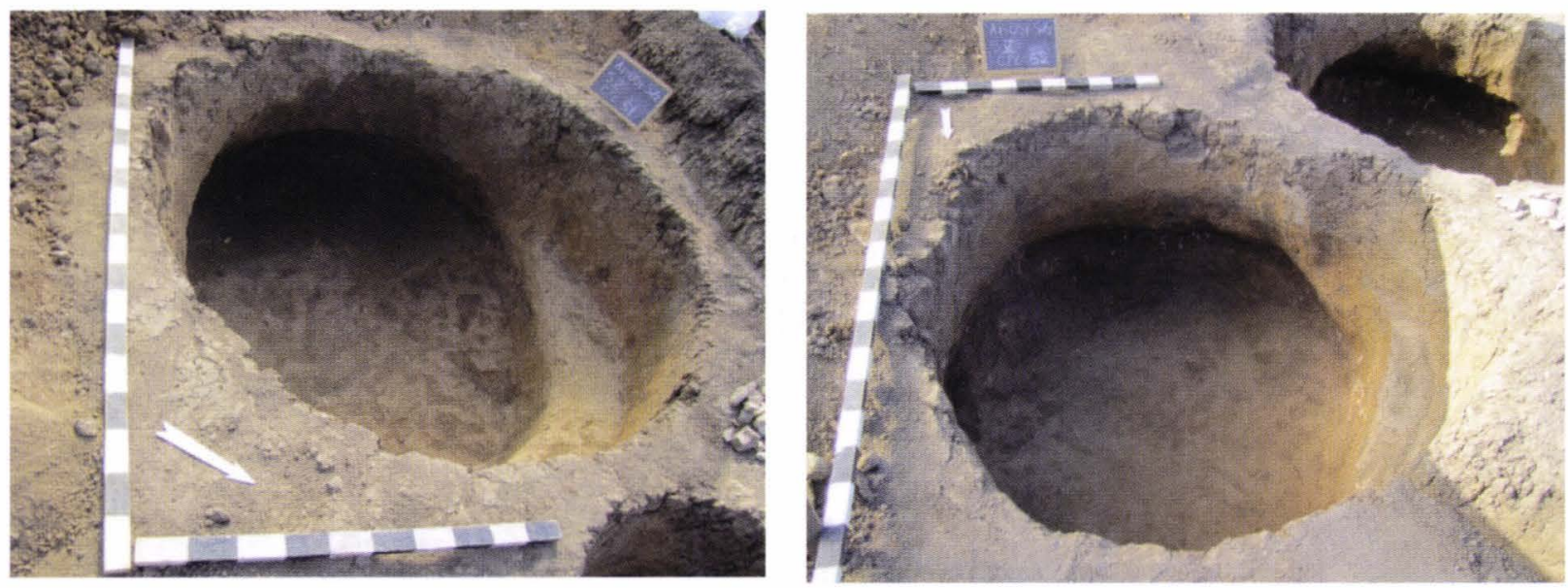

3.

Complexele 051-052, imagini de la conturare, secţionare şi finalizare: 1-3. Complexul 051, 4-5. Complexul 052 


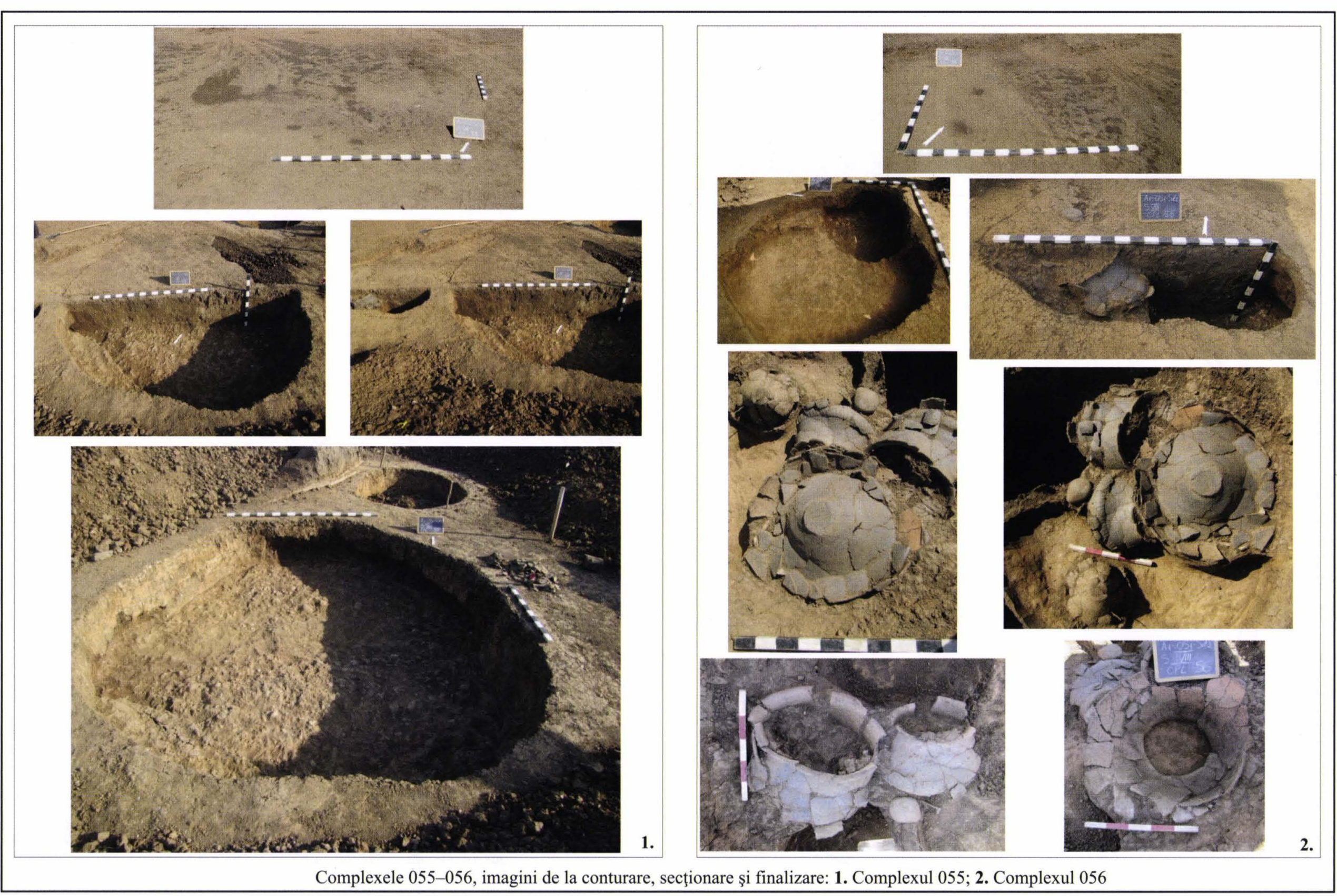

Pl. XVIII 

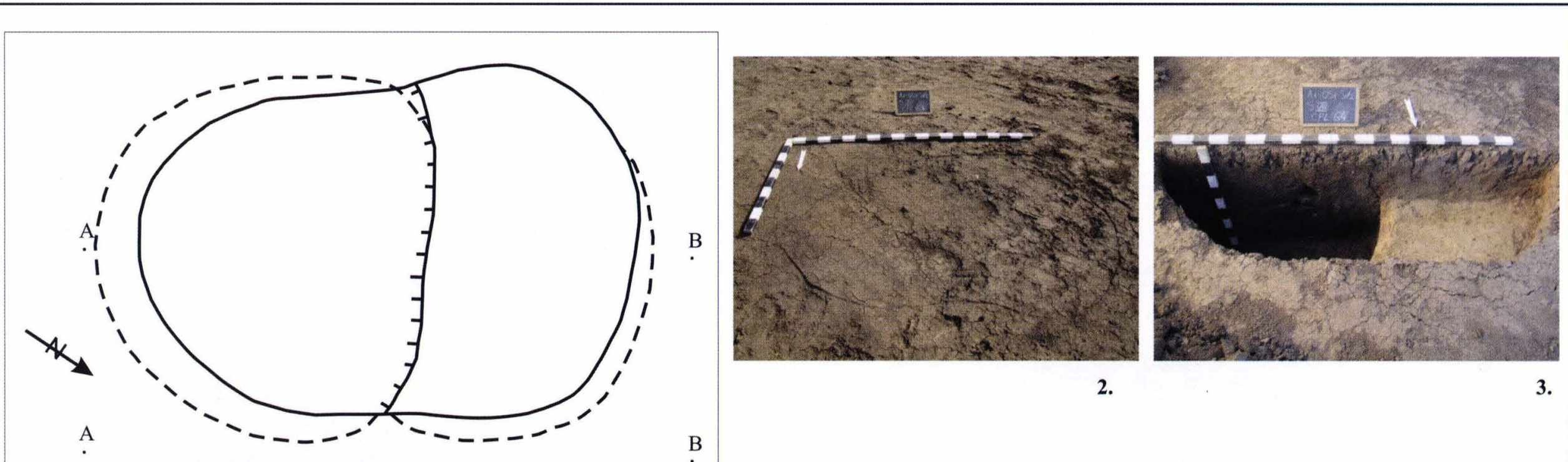

2.

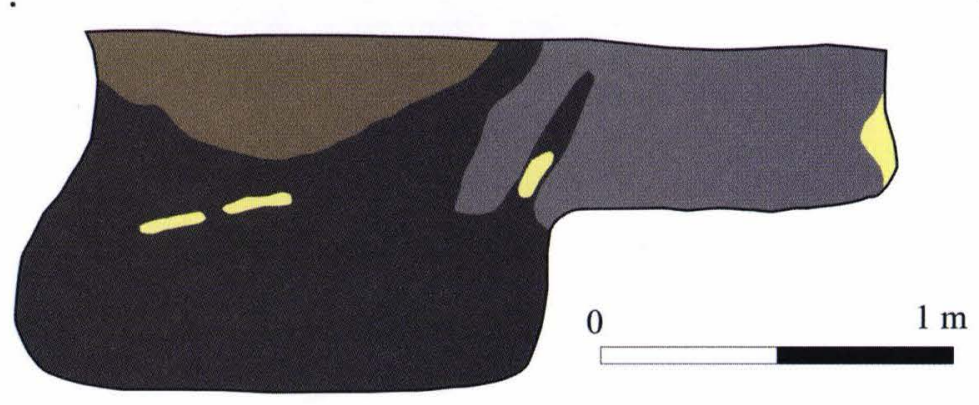

Pământ negru compact foarte slab pigmentat cu chirpici

Pământ cenuşiu făinos cu urme de chirpic şi cărbune

Pământ negru-gălbui cu urme de chirpic

Lentile de lut galben, steril

1.

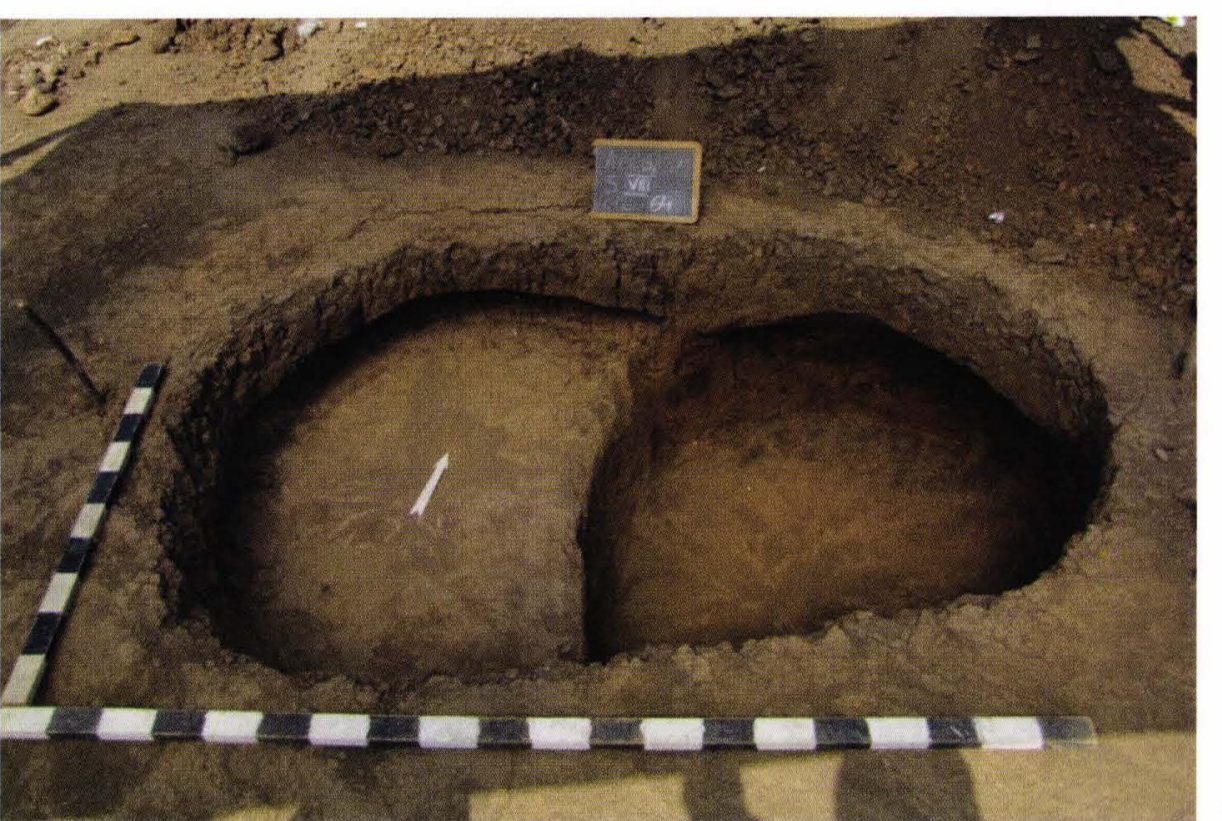

Complexul 064: 1. Desen grund şi profil; 2-4. Imagini de la conturare, secționare şi finalizare 


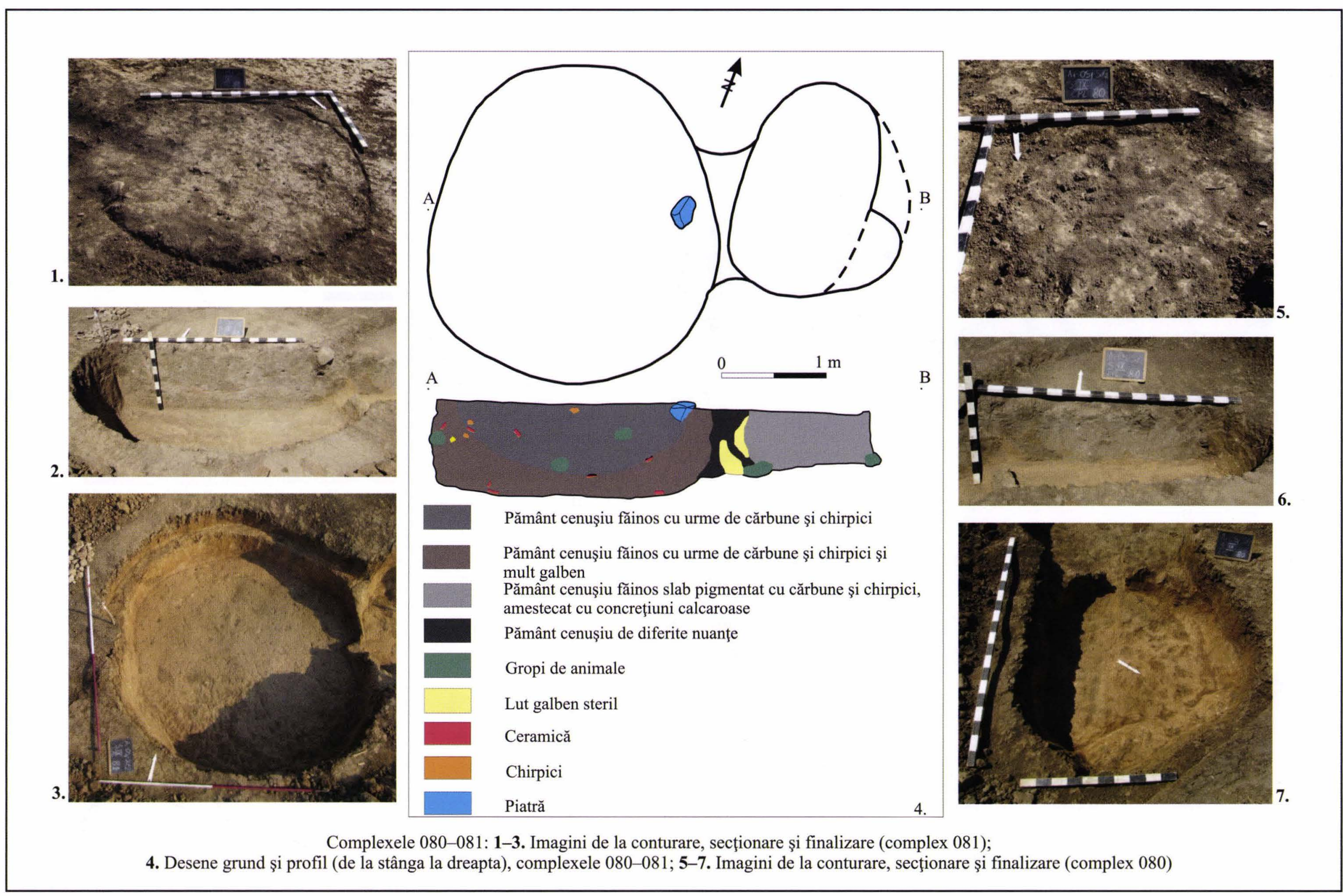




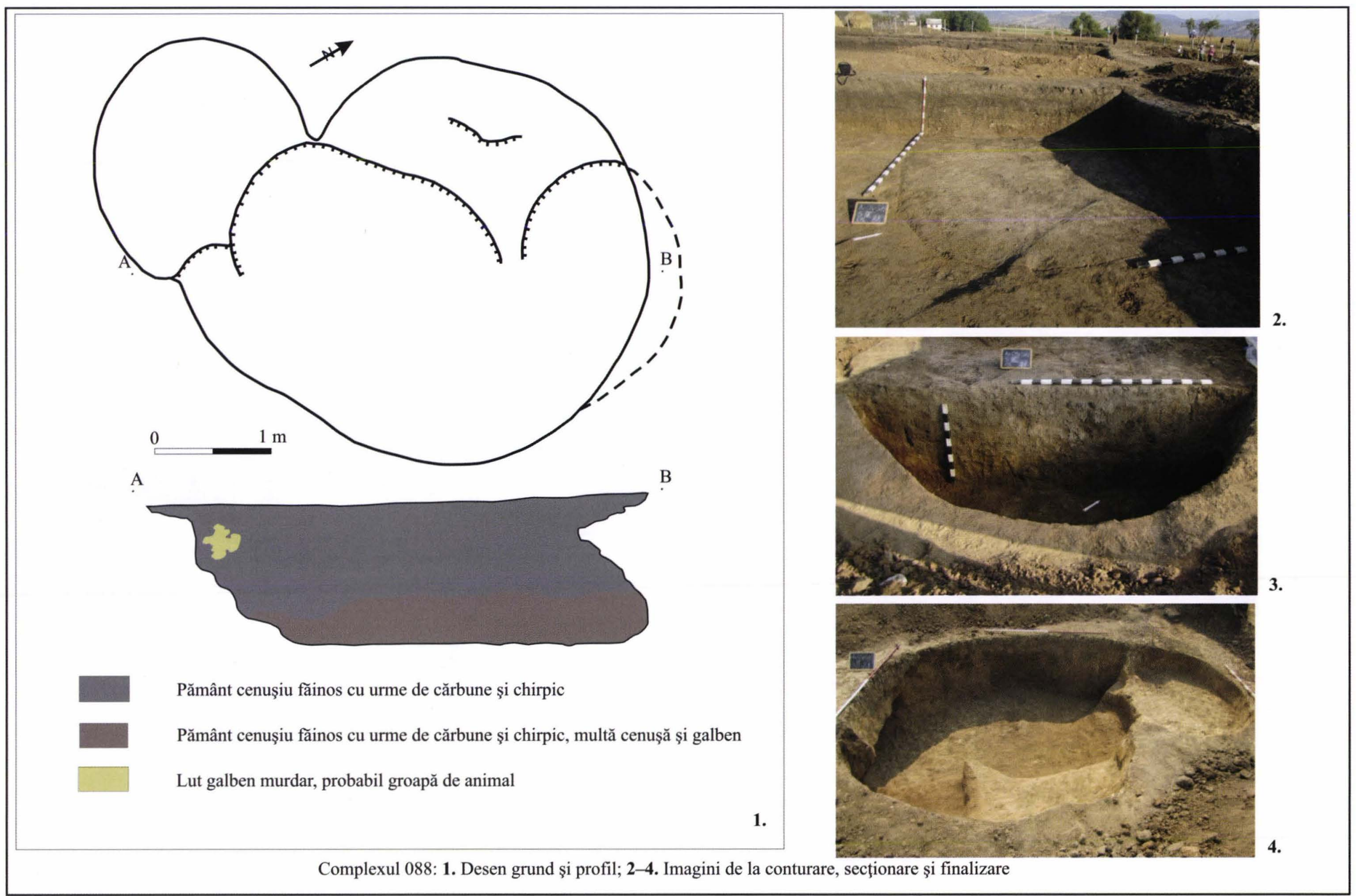

PI. XXIII 


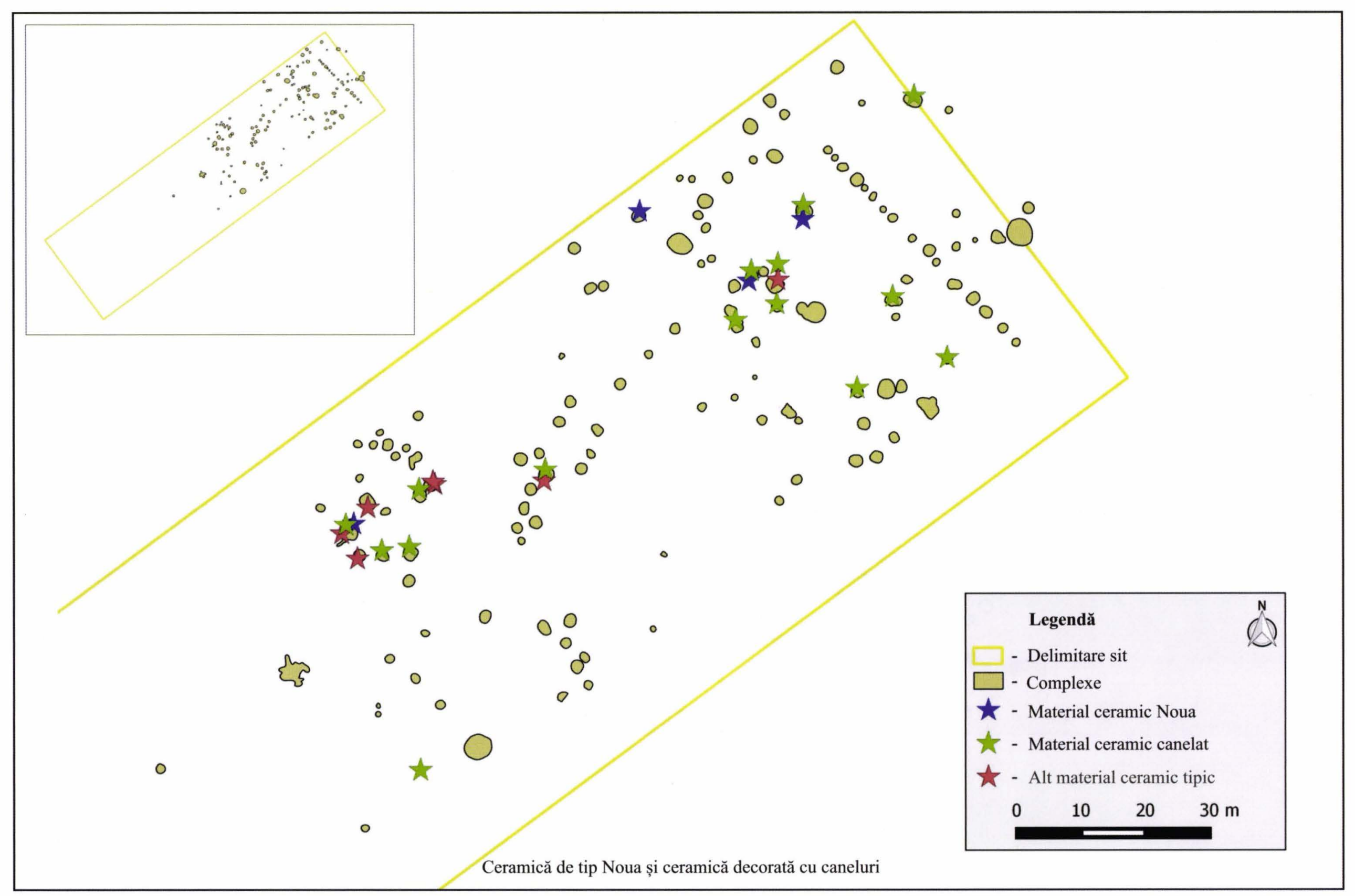

PI. XXVI 

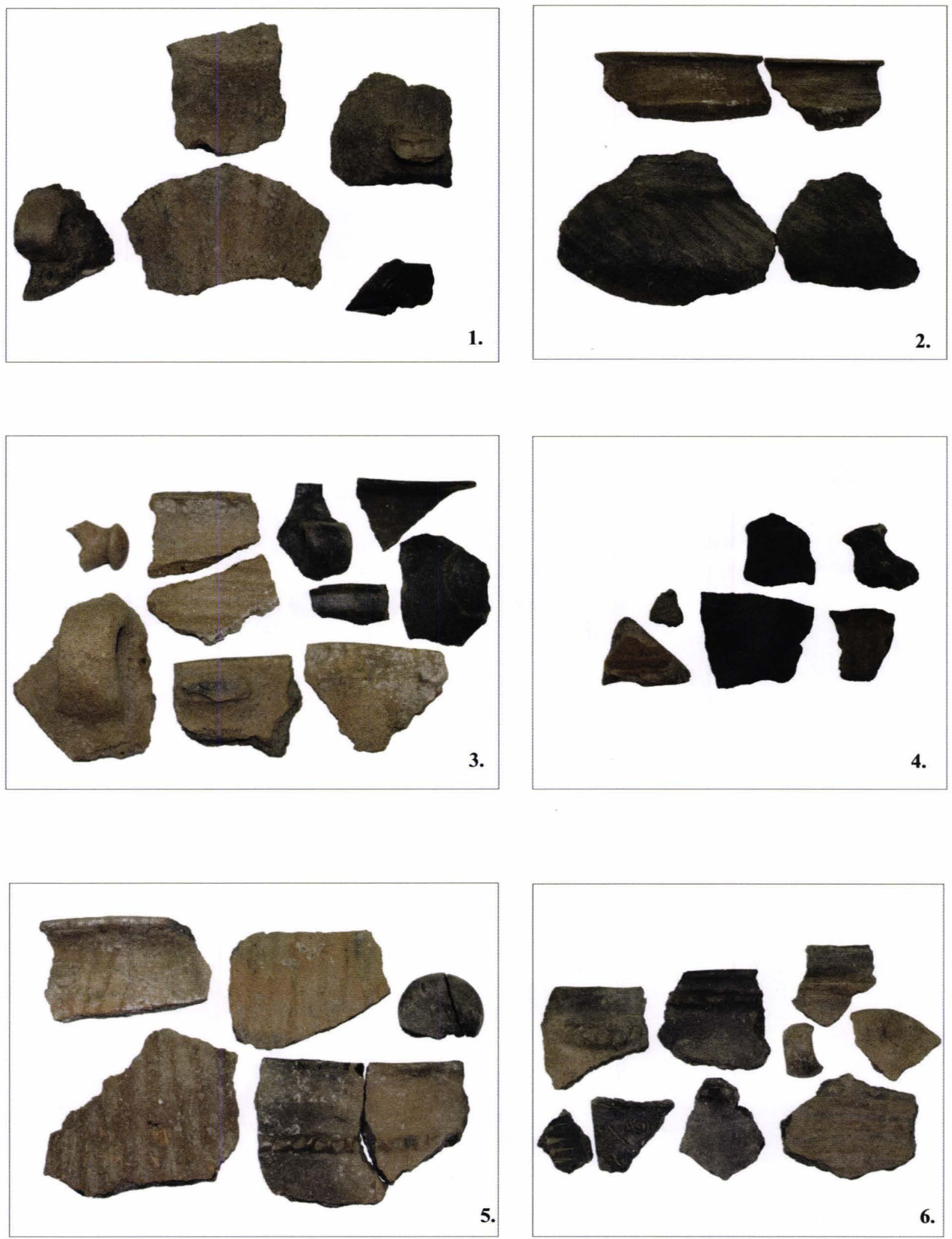

Fragmente ceramice tipice din inventarul complexelor (selectiv):

1. Complexul 013; 2-3. Complexul 012; 4. Complexul 015; 5. Complexul 016; 6. Complexul 017 

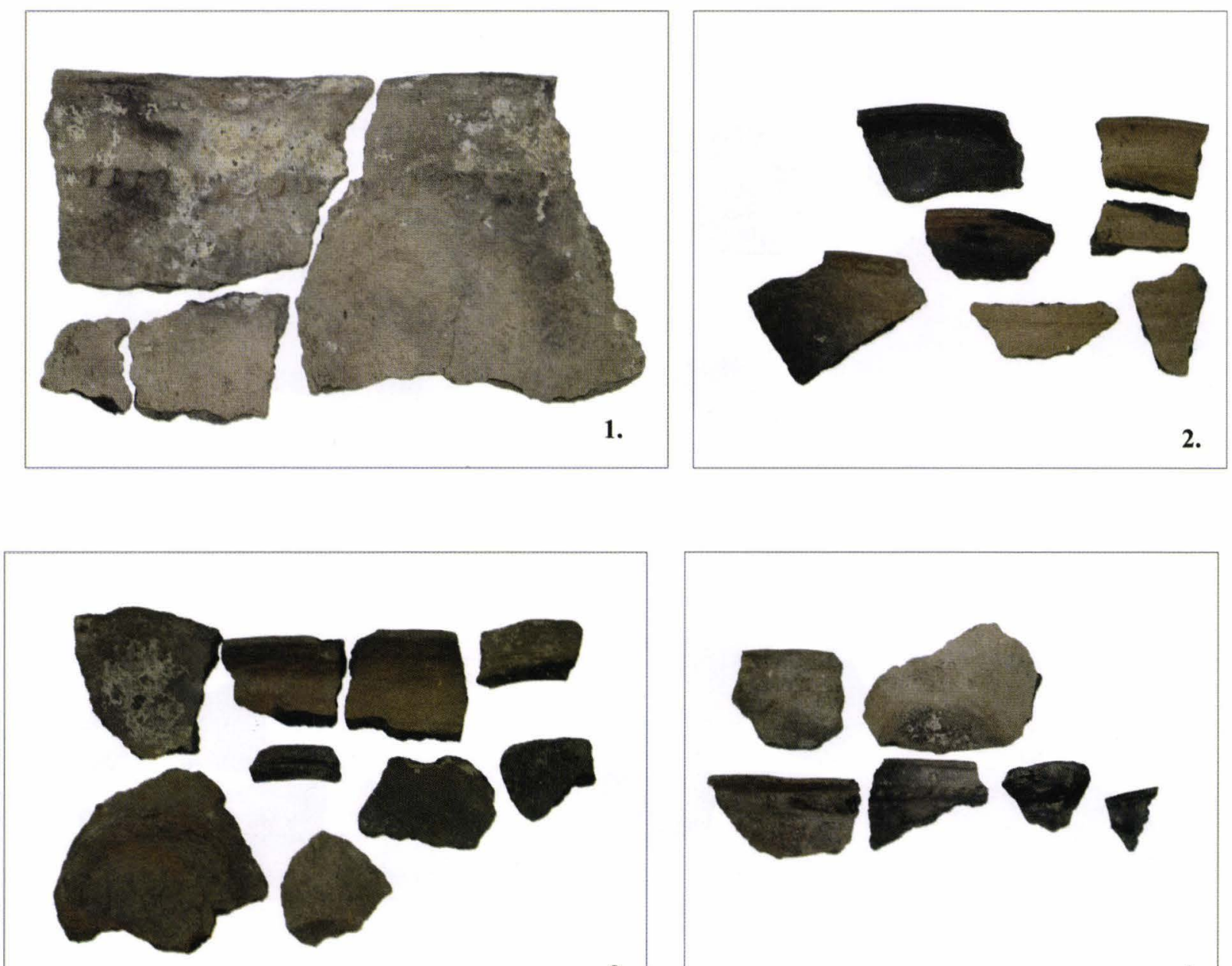

3.

4.
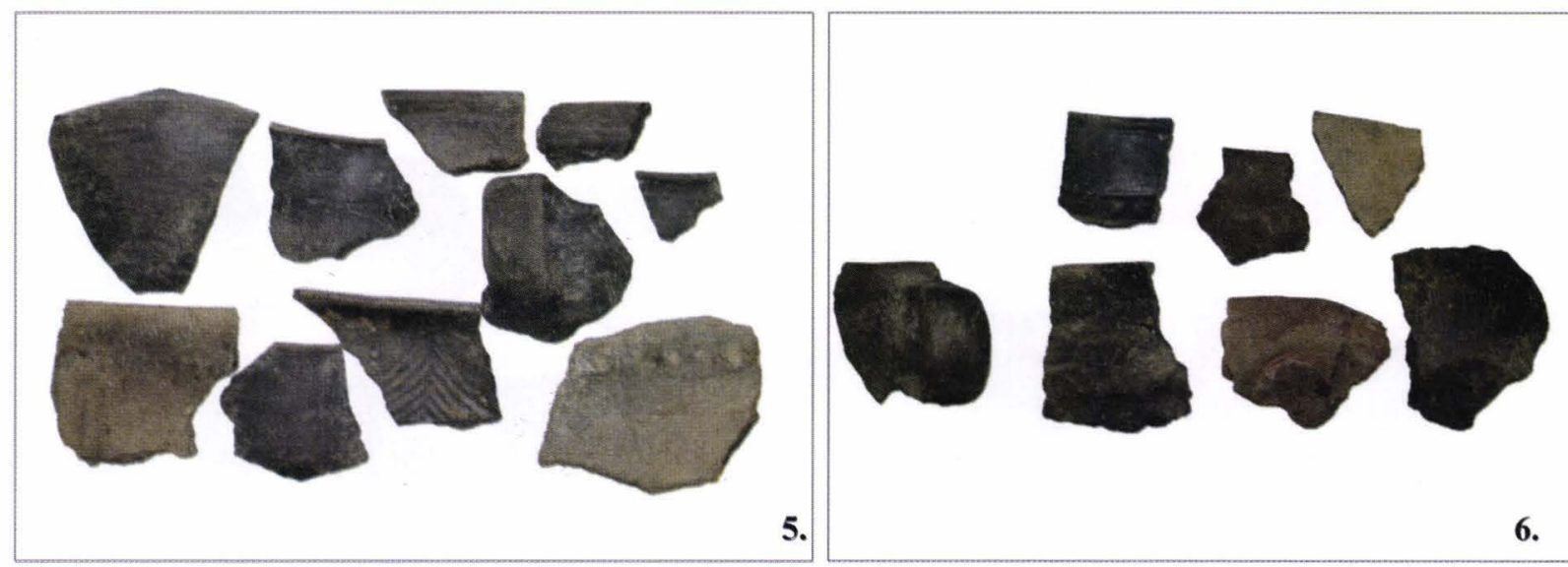

Fragmente ceramice tipice din inventarul complexelor (selectiv):

1. Complexul 043; 2. Complexul 036; 3. Complexul 030; 4. Complexul 033; 5. Complexul 041; 6. Complexul 018 

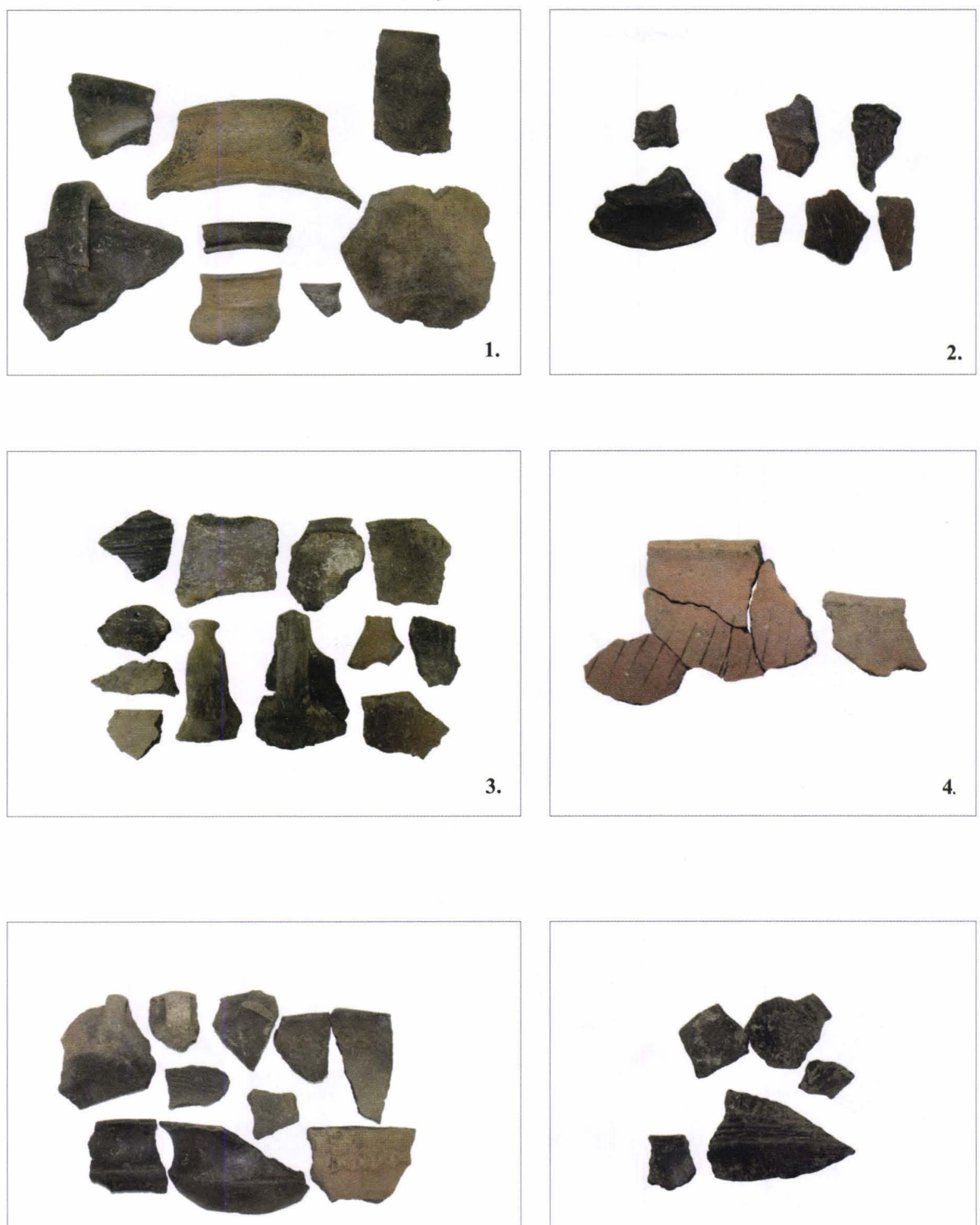

5.

6.

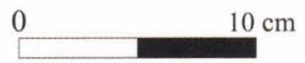

Fragmente ceramice tipice din inventarul complexelor (selectiv):

1. Complexul 047; 2. Complexul 052; 3. Complexul 048; 4. Complexul 067; 5. Complexul 055; 6. Complexul 051 



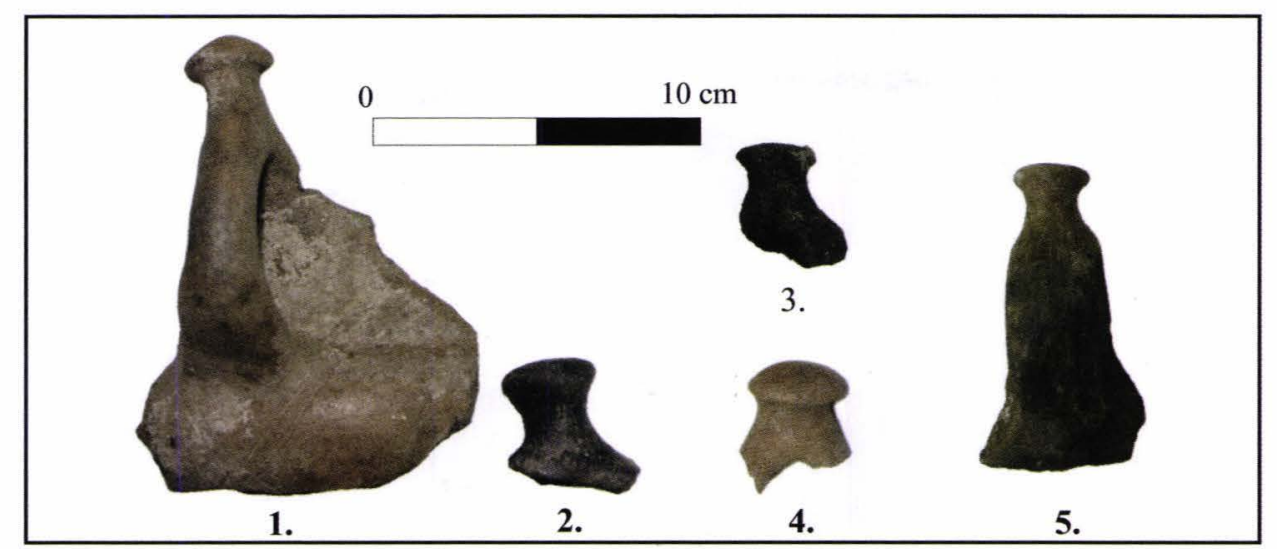

$\mathbf{A}$

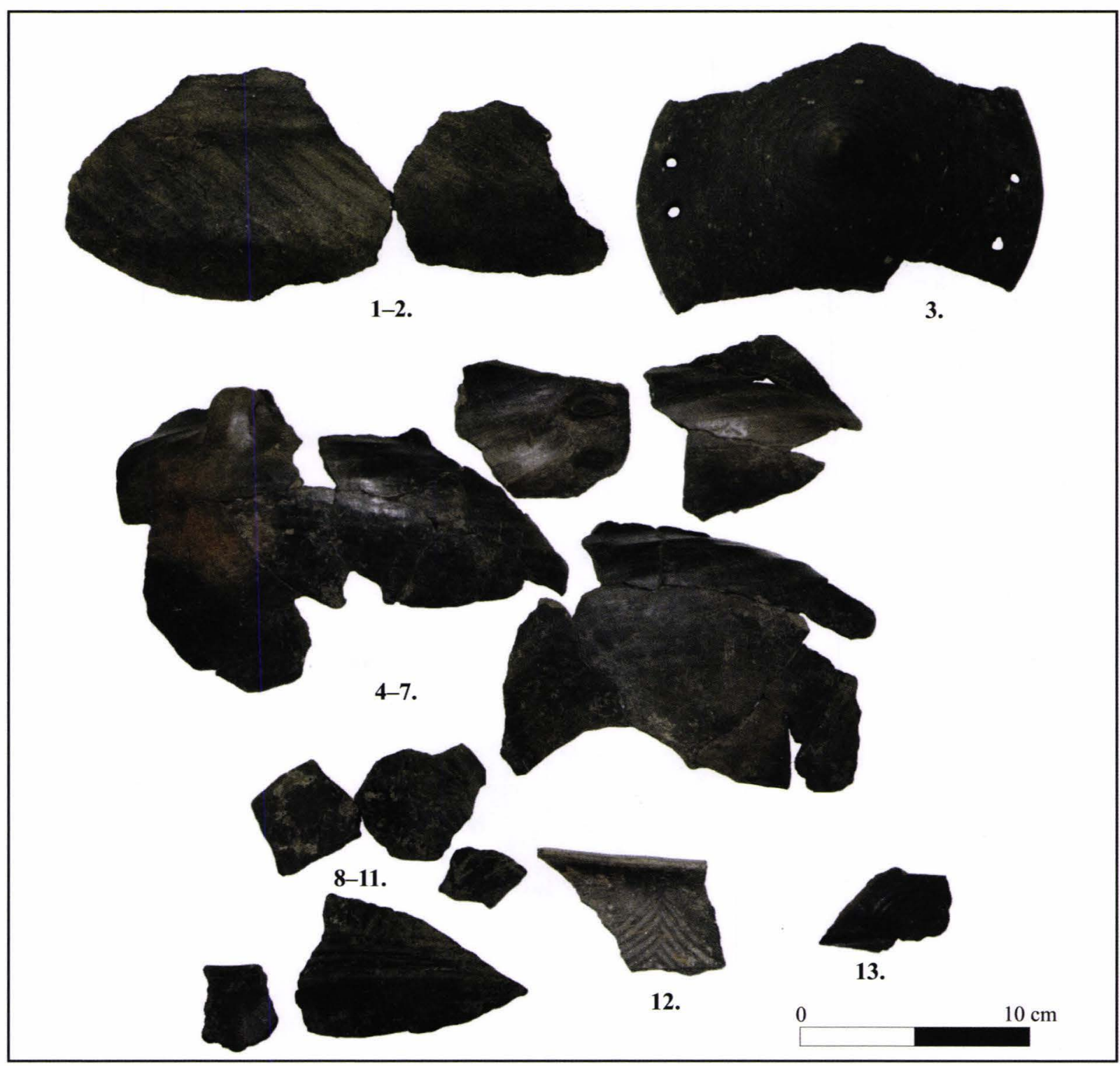

B

A. Fragmente ceramice cu decor de tip Noua (selectiv): 1-2. Complexul 120; 3. Complexul 015; 4. Complexul 012; 5. Complexul 048; B. Fragmente ceramice cu decor canelat (selectiv): 1-2. Complexul 012; 3. Complexul 001; 4-7. Complexul 097; 8-11. Complexul 051; 12. Complexul 041; 13. Complexul 013 


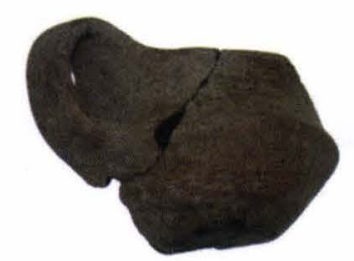

1.

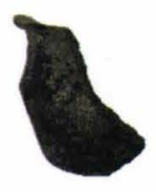

2.

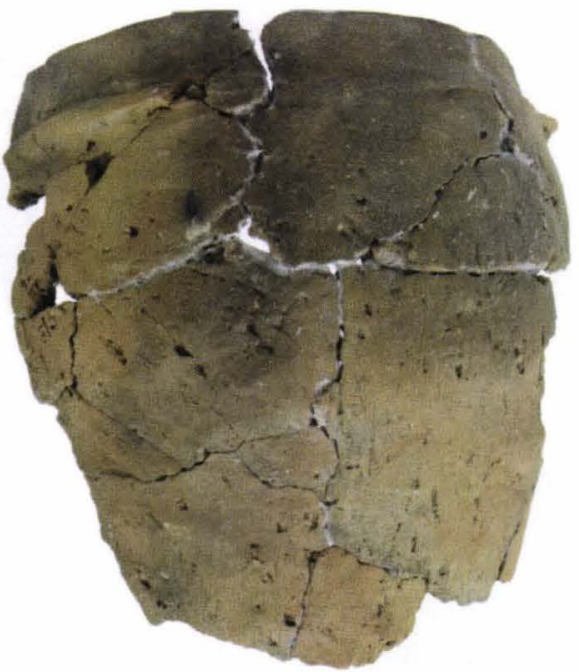

5.

\section{.}

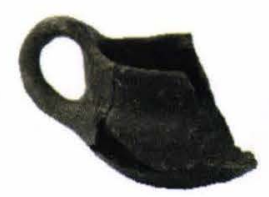

3.

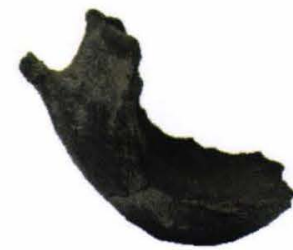

4.

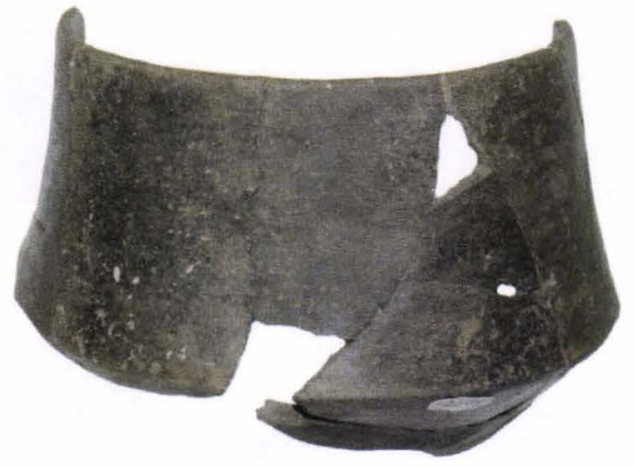

6.
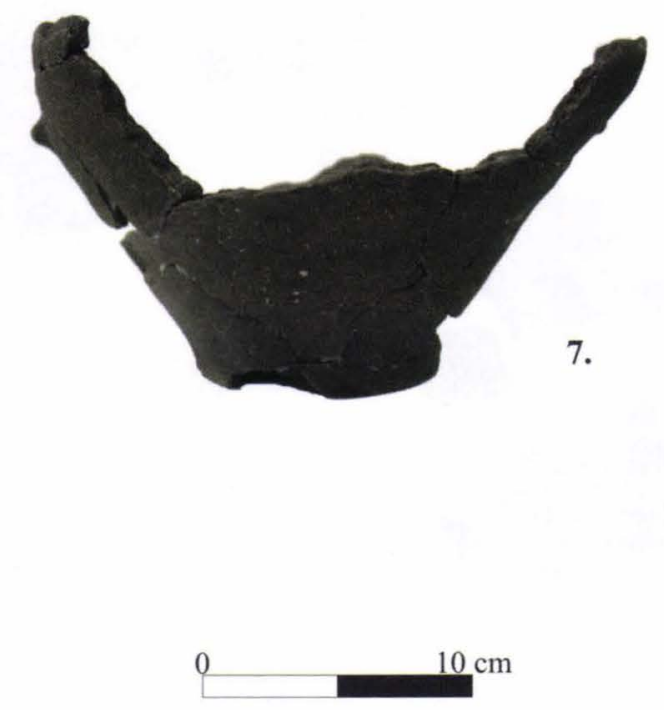

Vase ceramice restaurate (selectiv): 1-2. Complexul 081; 2. Complexul 111; 3. CPLomplexul 033; 4. Complexul 053; 5. strat; 6. Complexul 100; 7. strat 

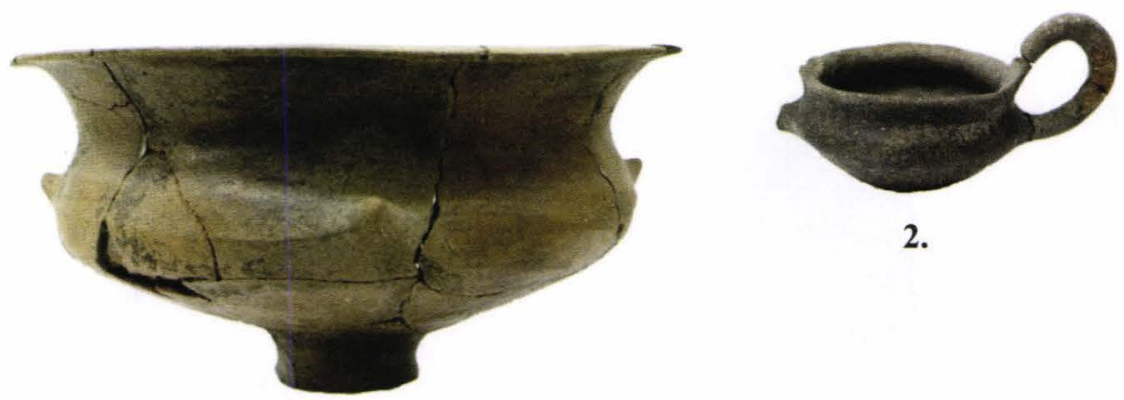

2.

1.

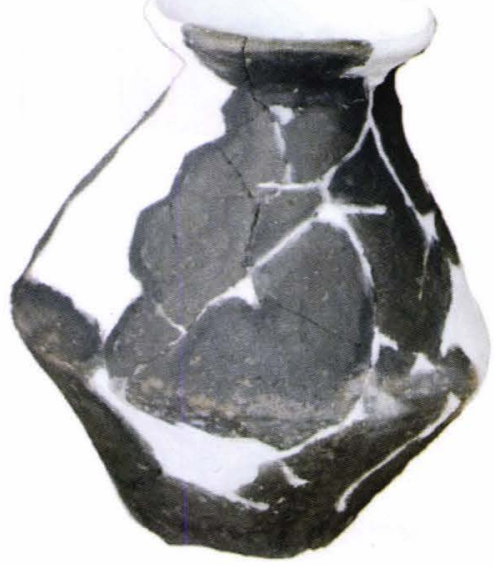

4.

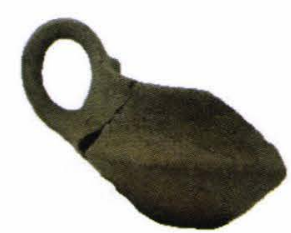

3.

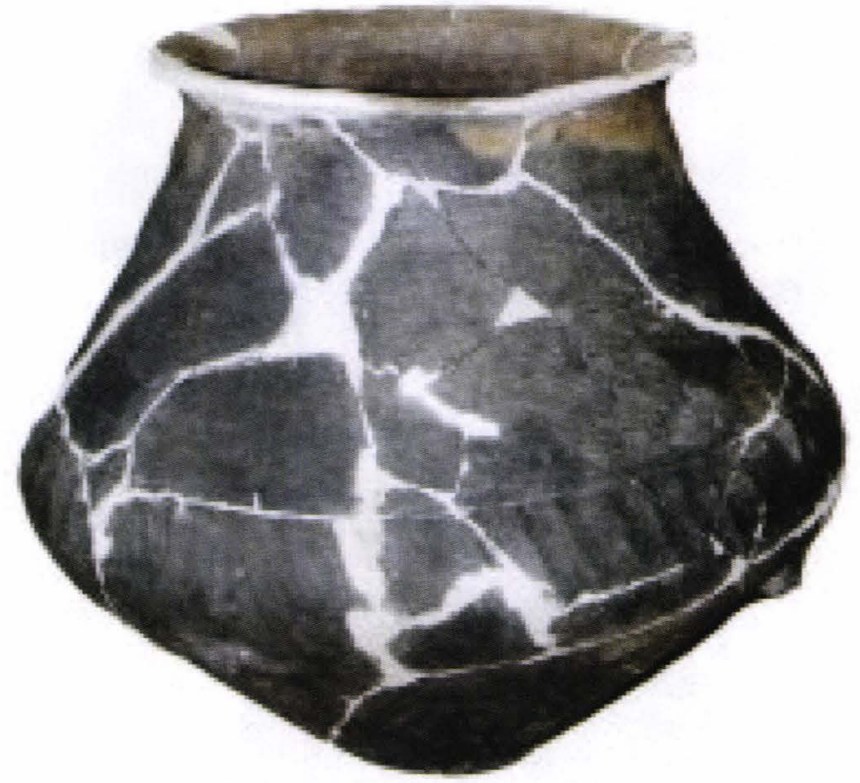

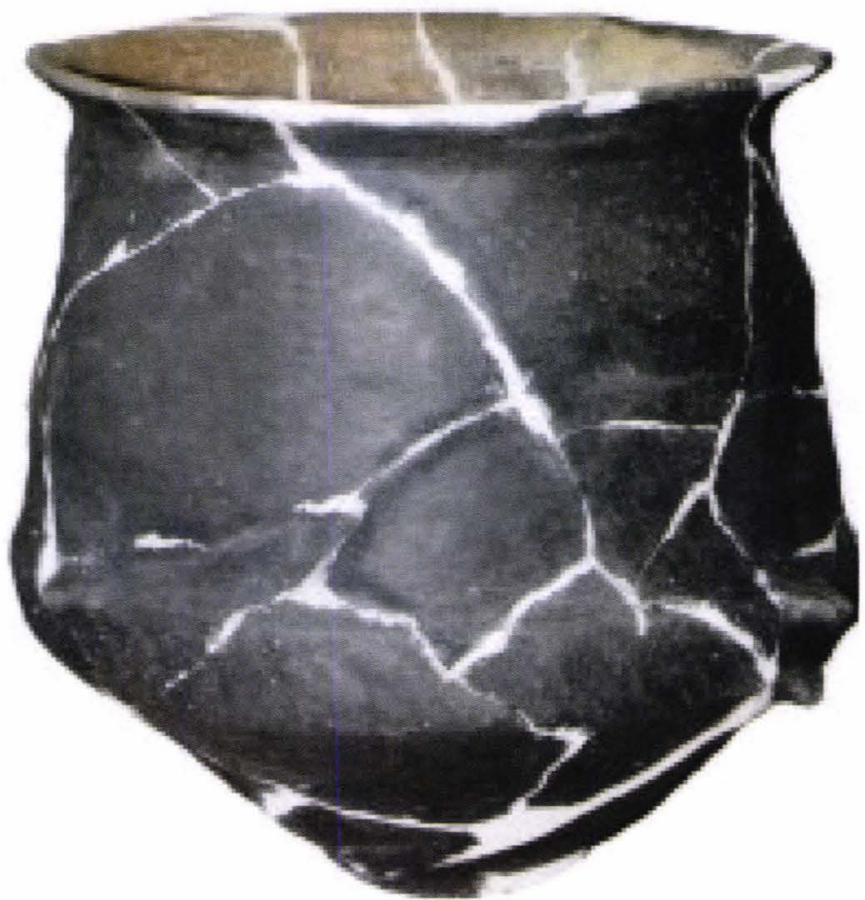

6.
5.

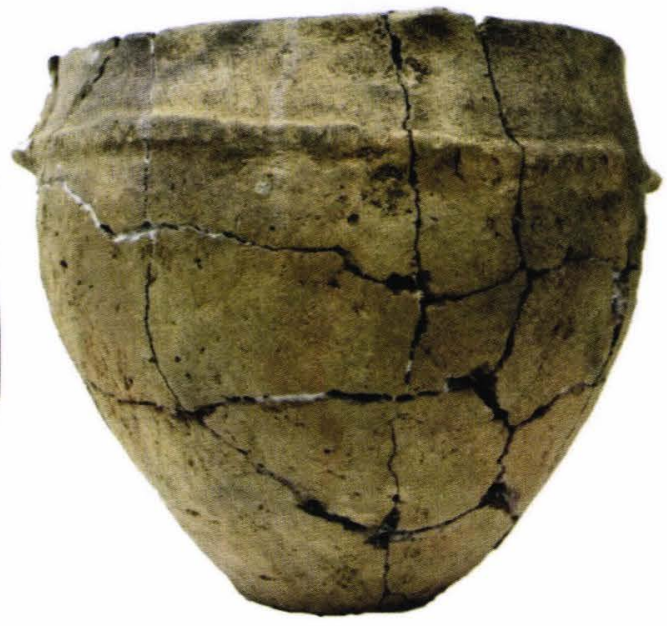

7.

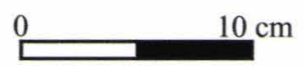

Vase ceramice restaurate (selectiv): 1. Profil magistral nordic al S. V; 2. Complexul 111; 3. Complexul 081; 4-7. Complexul 056 

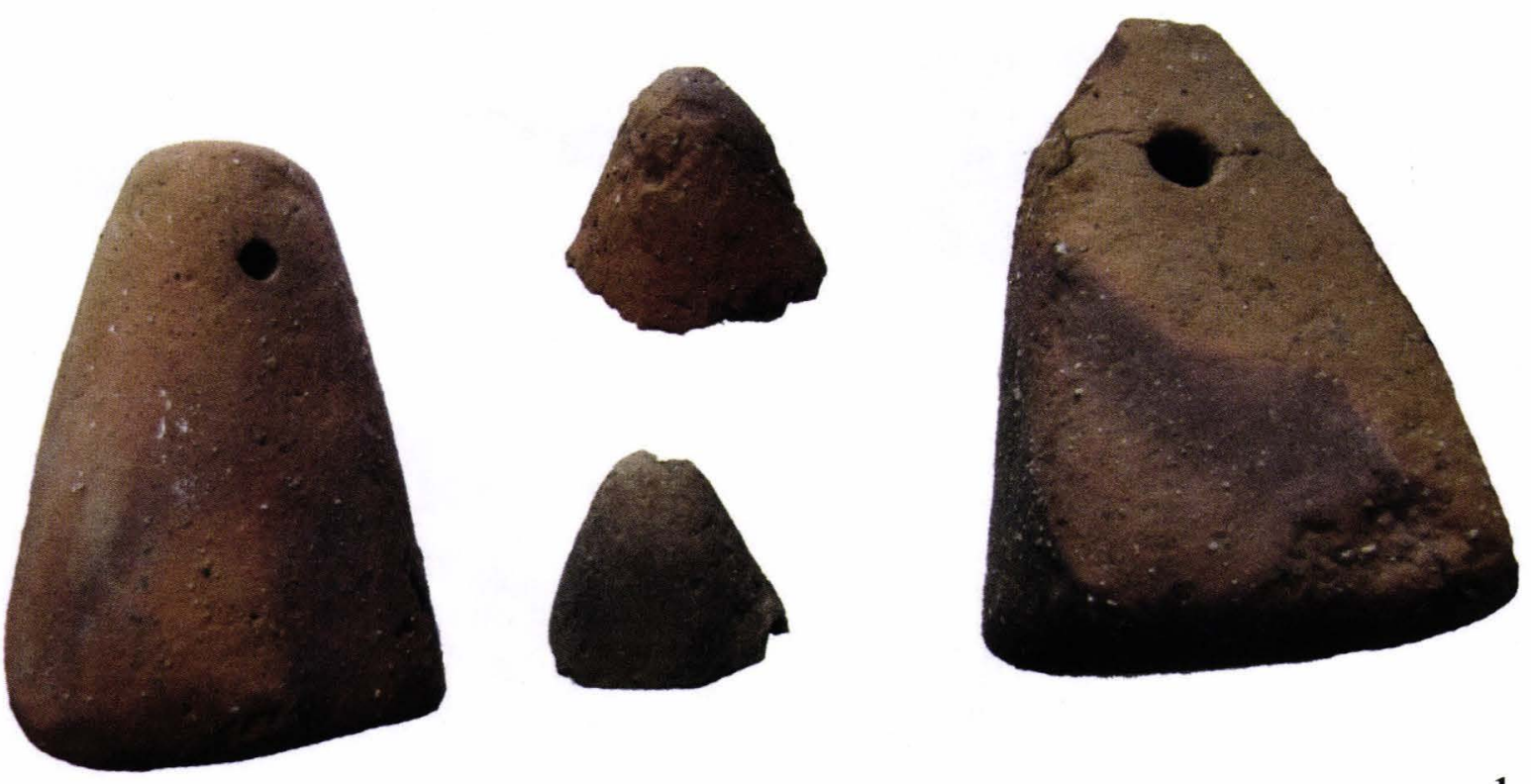

1.
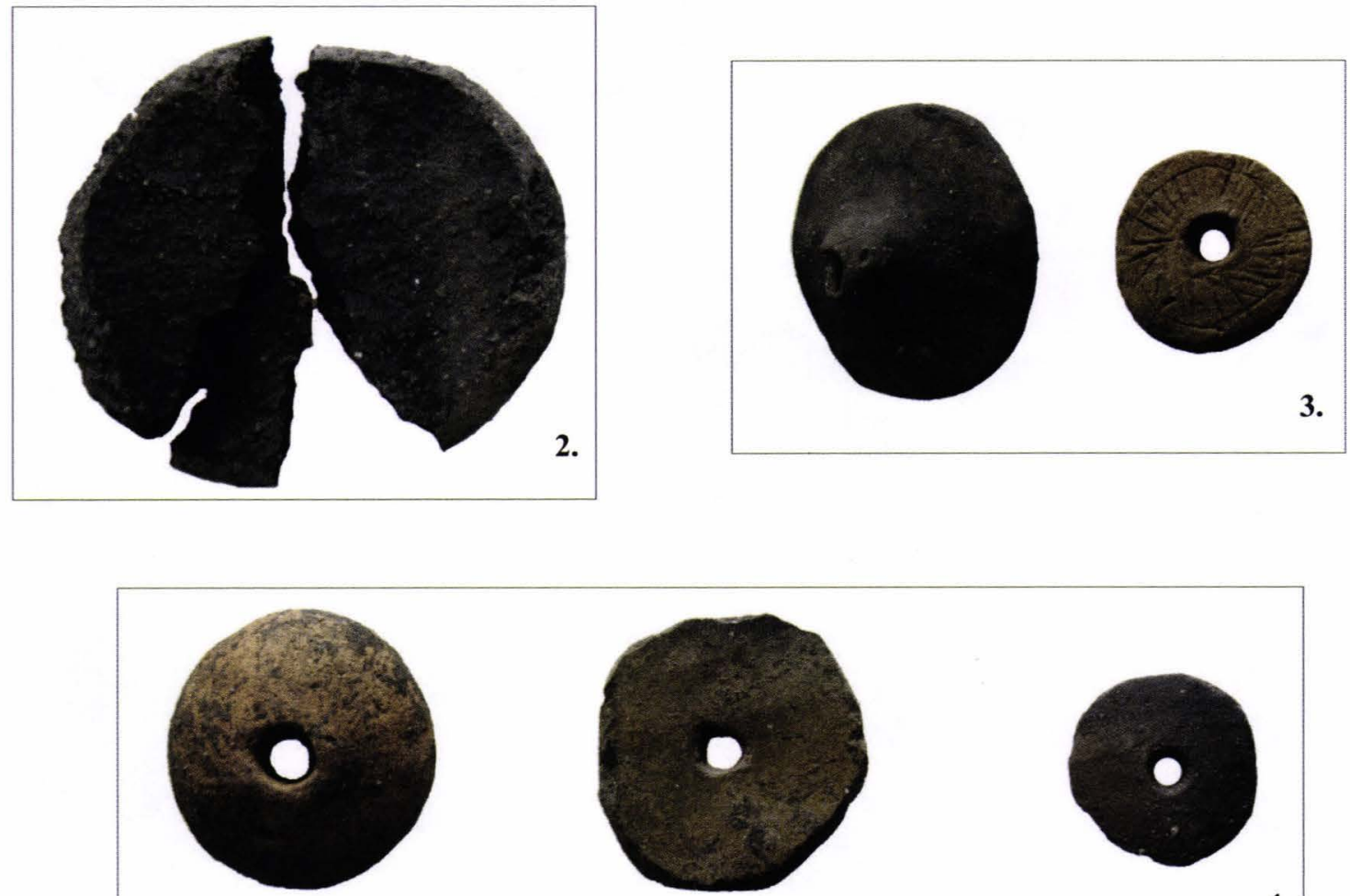

4.

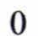

$10 \mathrm{~cm}$

Piese din lut: 1. „Căţei” de vatră/greutăţi; 2. Disc neperforat; 3. Rotiţe de car miniatural; 4. Fusaiole/disc perforat 

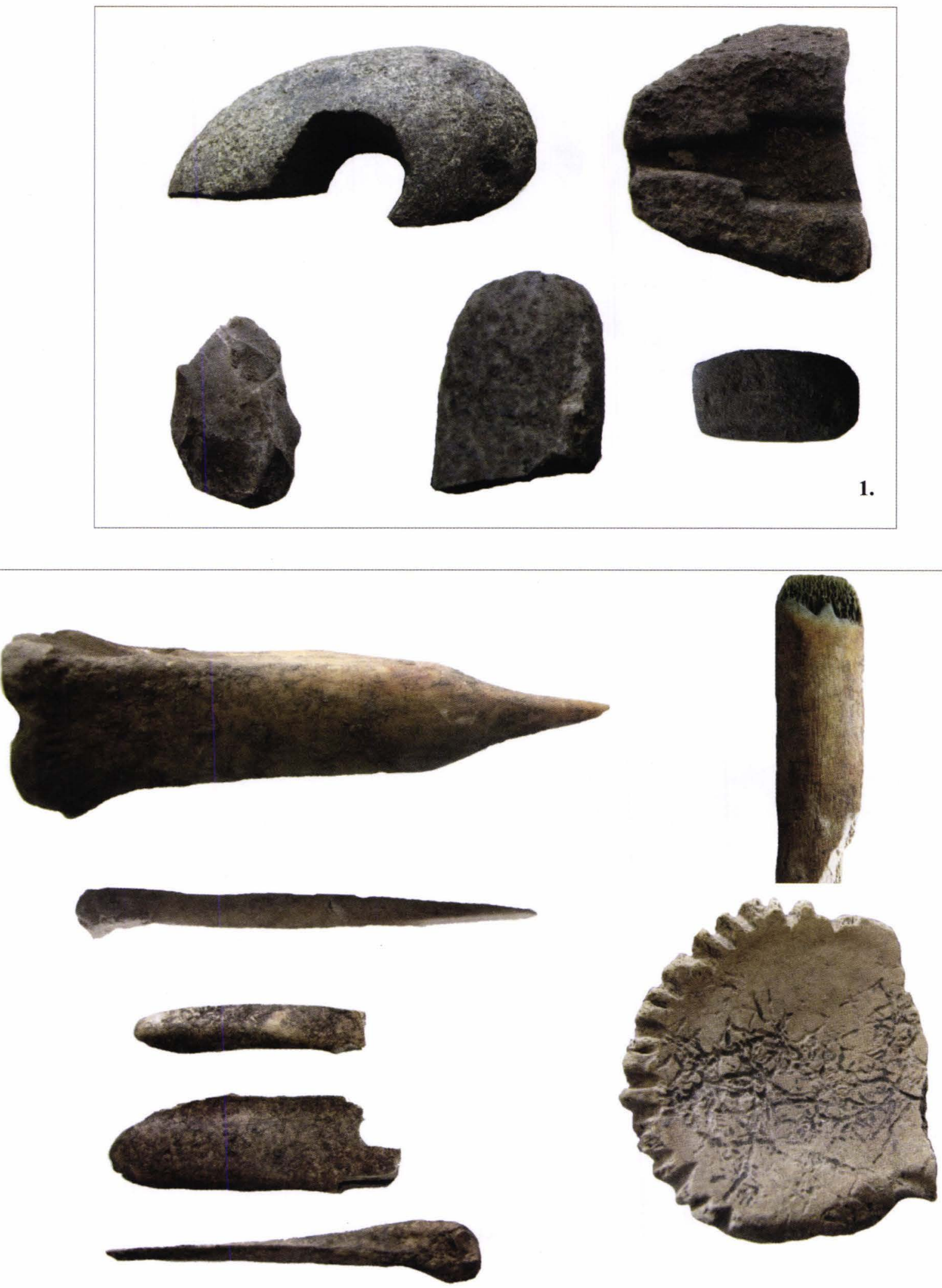

2.

0

$10 \mathrm{~cm}$

1. Material litic (unelte şi forme/tipare de turnare); 2. Piese din os prelucrat 


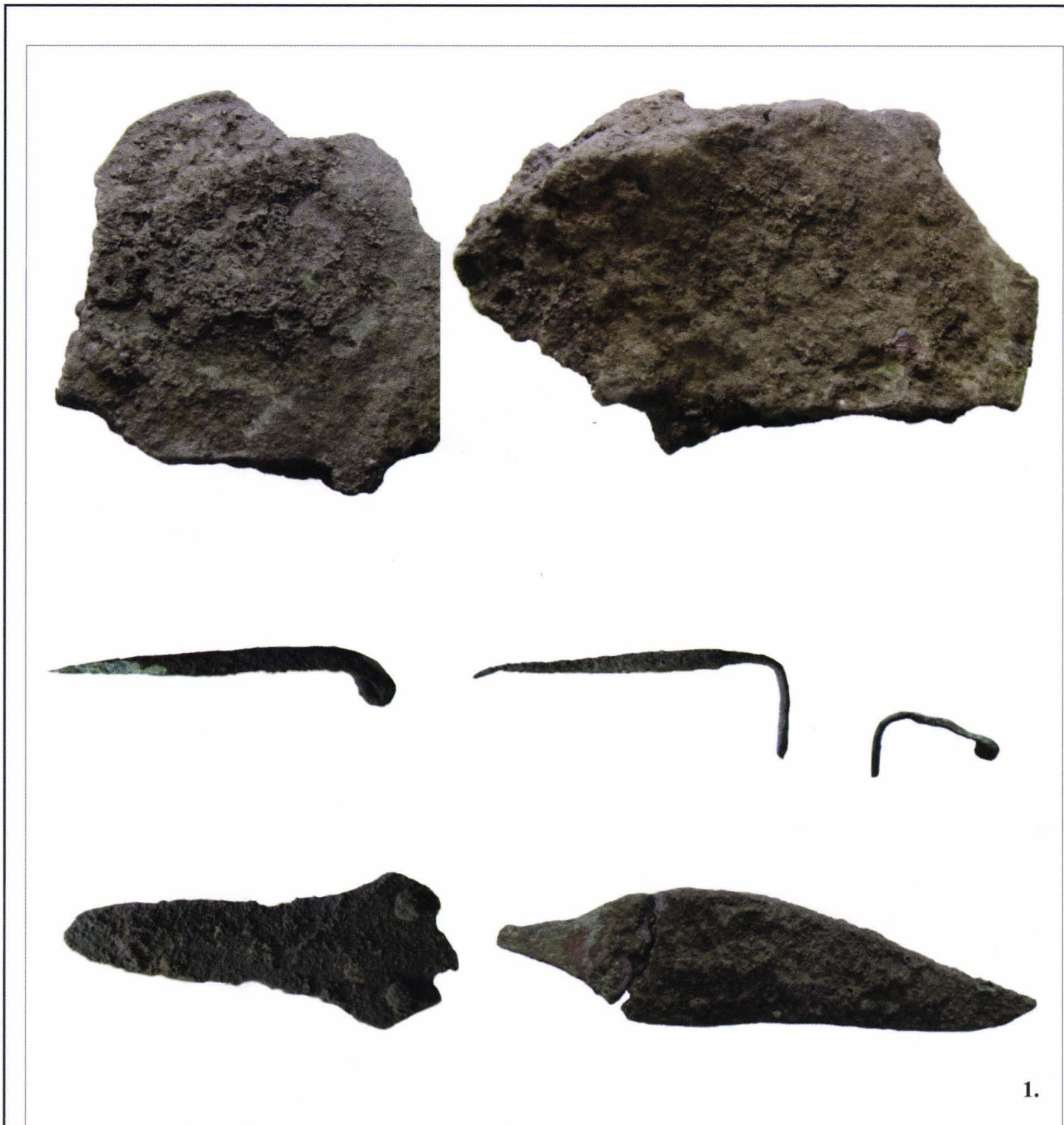

1.

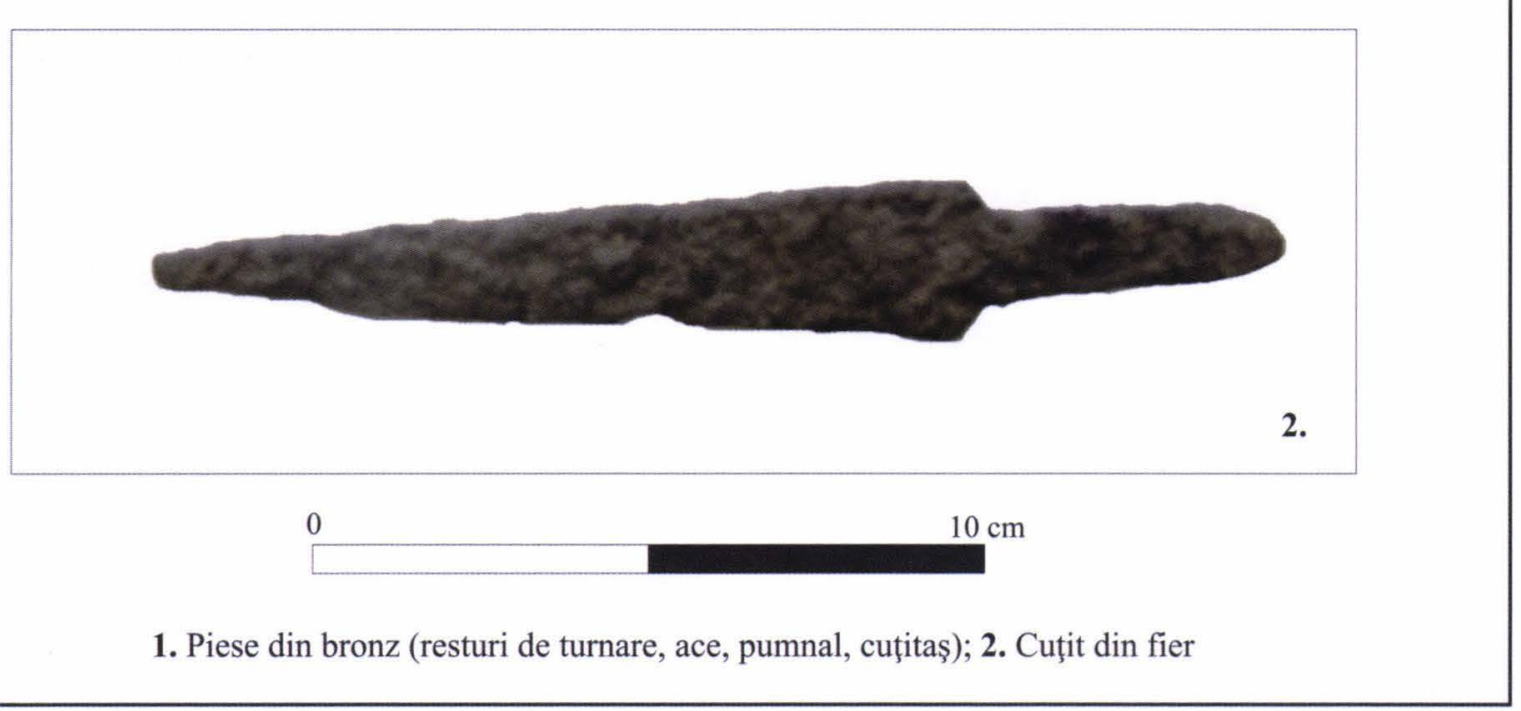



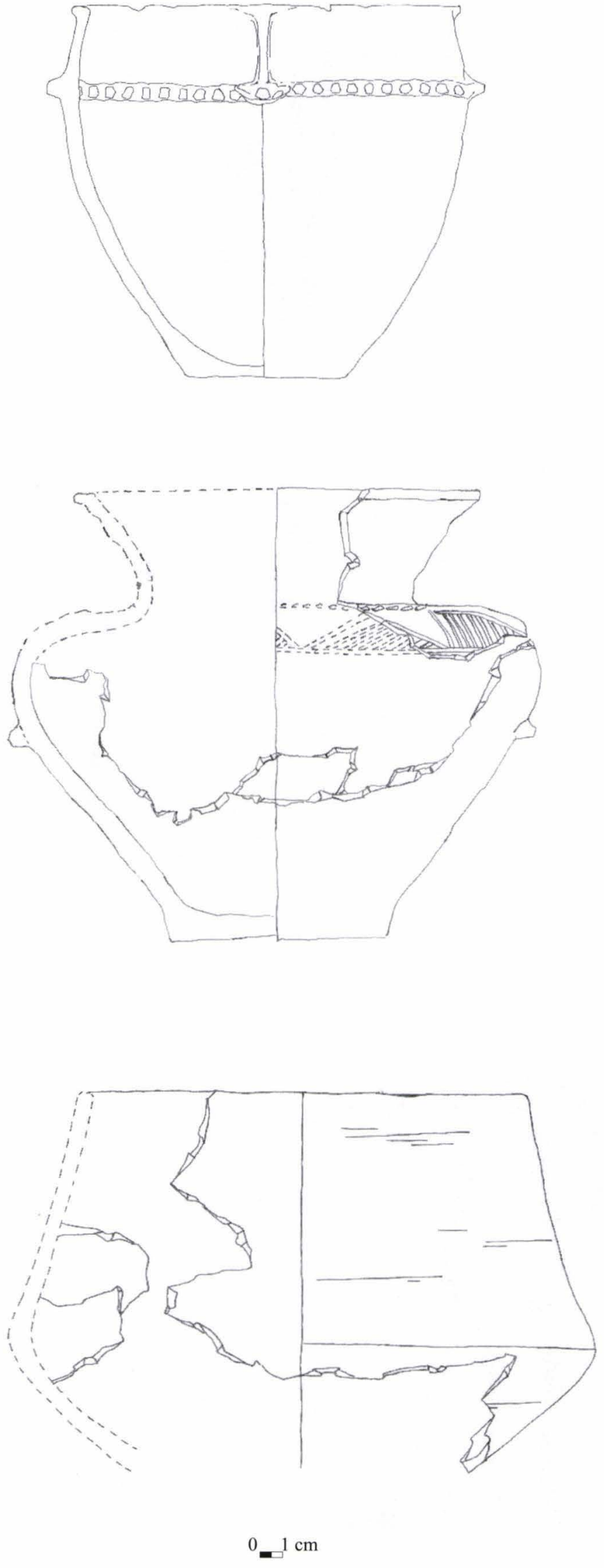

Desene vase ceramice restaurate (selectiv)

\section{PI. XXXVII}



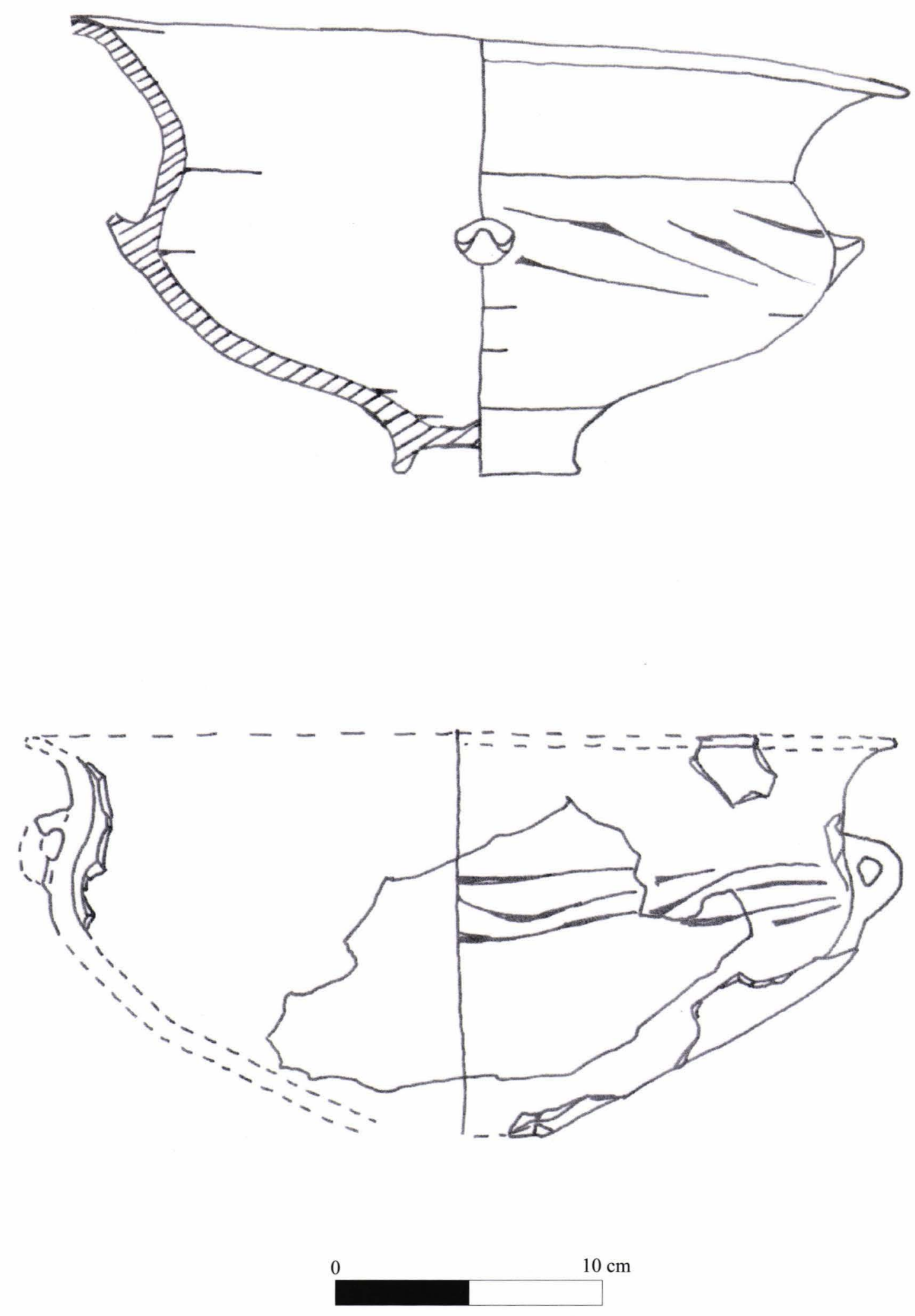

Desene vase ceramice restaurate (selectiv) 

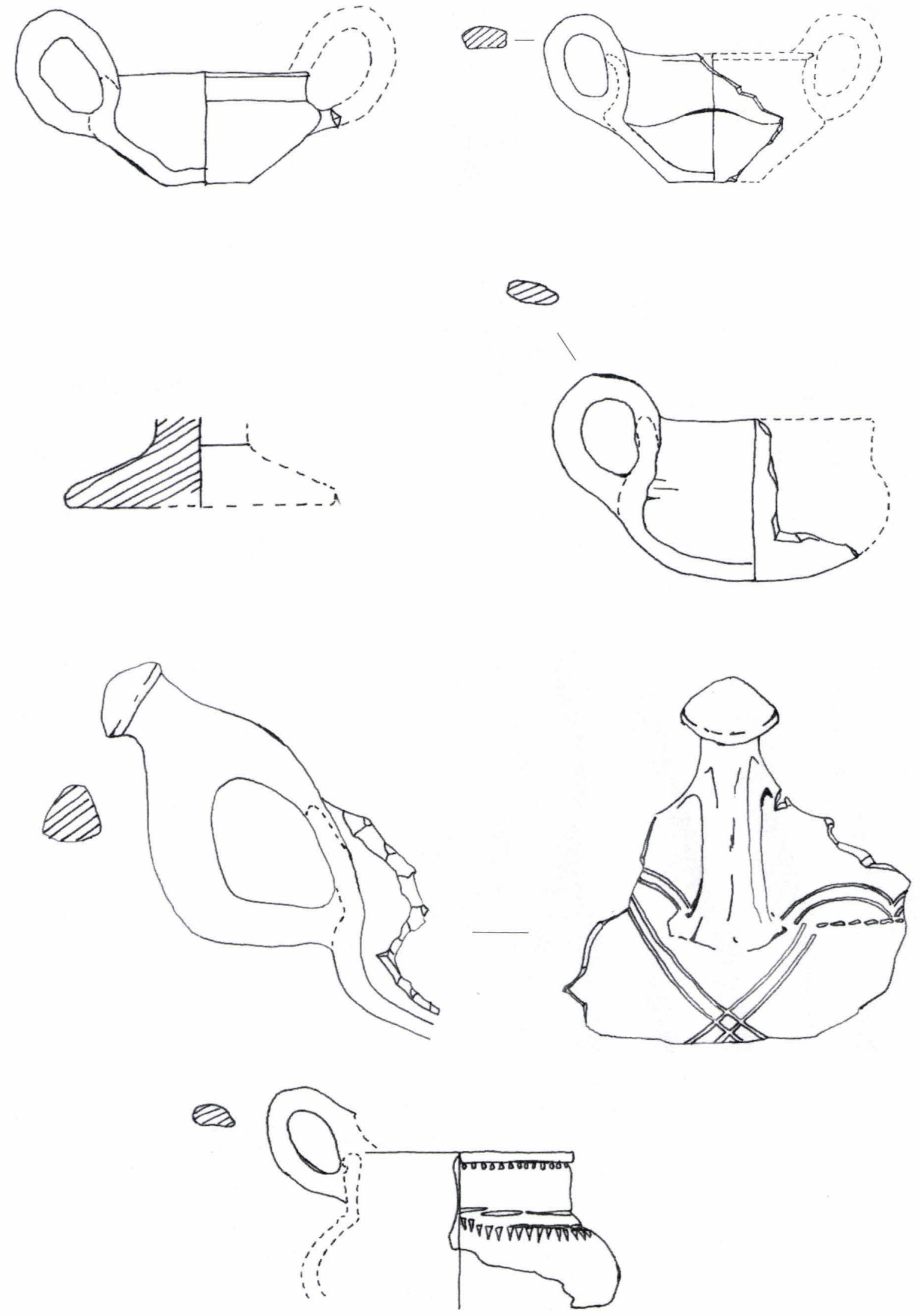

$0.1 \mathrm{~cm}$

Desene vase ceramice restaurate (selectiv)

\section{PI. XXXIX}



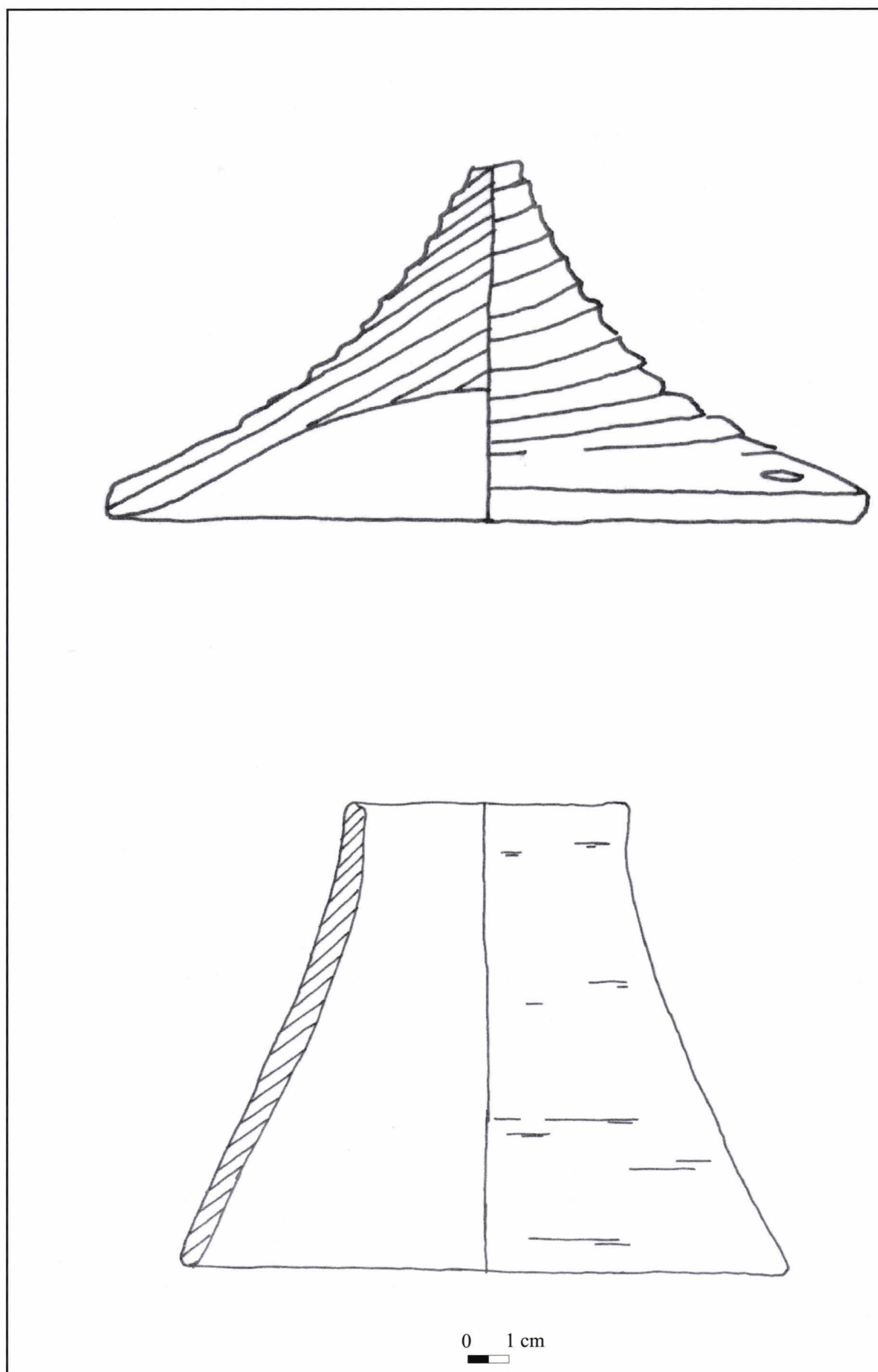

Desene vase ceramice restaurate (selectiv)

PI. XL 